\title{
POTENTIAL FOR SALTWATER INTRUSION INTO THE UPPER FLORIDAN AQUIFER, HERNANDO AND \\ MANATEE COUNTIES, FLORIDA
}

By Gary L. Mahon

\section{U.S. GEOLOGICAL SURVEY}

Water-Resources Investigations Report 88-4171

Prepared in cooperation with the

SOUTHWEST FLORIDA WATER MANAGEMENT DISTRICT

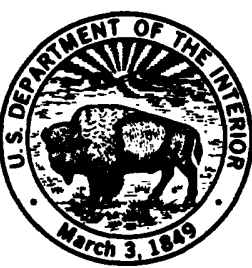

Tallahassee, Florida 1989 


\section{DEPARTMENT OF THE INTERIOR \\ MANUEL LUJAN, JR., Secretary}

\section{U.S. GEOLOGICAL SURVEY}

Dallas L. Peck, Director

For additional information write to:

District Chief

U.S. Geological Survey

Suite 3015

227 North Bronough Street

Tallahassee, Florida 32301
Copies of this report may be purchased from:

U.S. Geological Survey

Books and Open-File Reports

Federal Center, Building 810

Box 25425

Denver, Colorado 80225 


\section{CONTENTS}

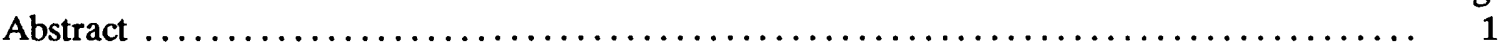

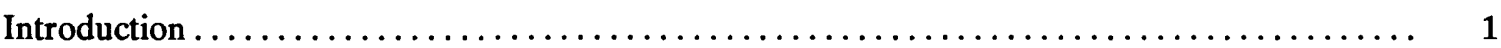

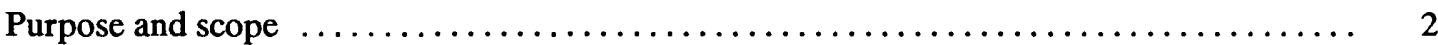

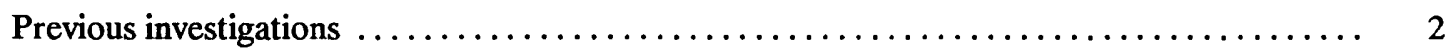

Description of study areas $\ldots \ldots \ldots \ldots \ldots \ldots \ldots \ldots \ldots \ldots \ldots \ldots \ldots \ldots \ldots \ldots \ldots \ldots \ldots \ldots \ldots \ldots, 2$

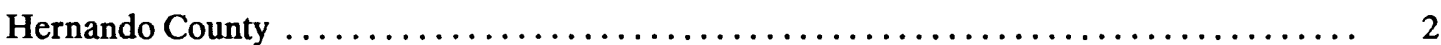

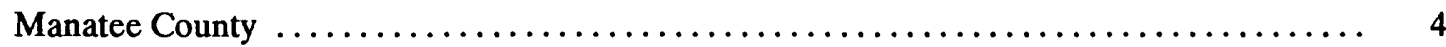

Hydrogeologic framework and hydraulic characteristics $\ldots \ldots \ldots \ldots \ldots \ldots \ldots \ldots \ldots, 4$

Ground-water flow system in the Upper Floridan aquifer $\ldots \ldots \ldots \ldots \ldots \ldots \ldots \ldots \ldots \ldots$

Predevelopment potentiometric surface, recharge, and discharge $\ldots \ldots \ldots \ldots \ldots \ldots \ldots \ldots .8$

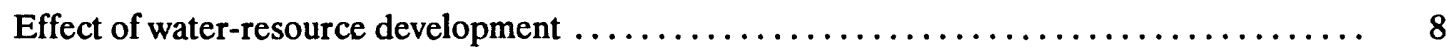

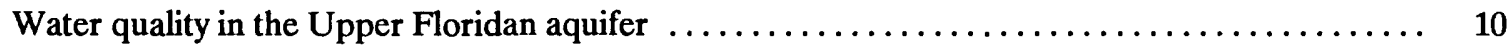

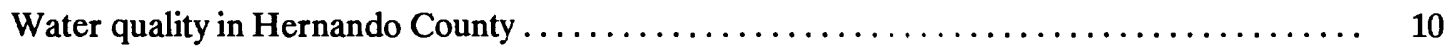

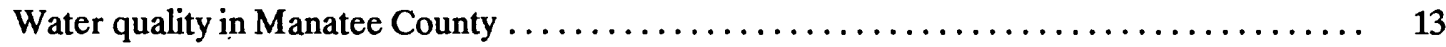

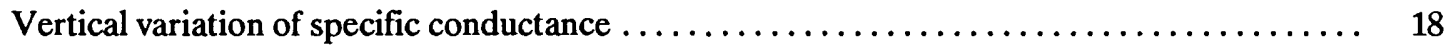

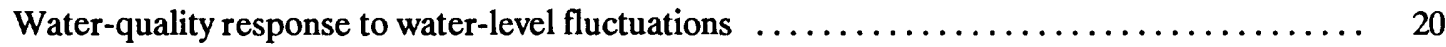

Interface theory and cyclic seawater flow in the zone of transition $\ldots \ldots \ldots \ldots \ldots \ldots \ldots . \ldots \ldots$

Simulation of the ground-water system with numerical models $\ldots \ldots \ldots \ldots \ldots \ldots \ldots \ldots \ldots .26$

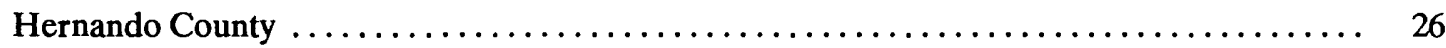

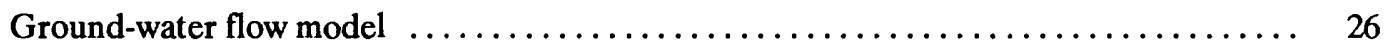

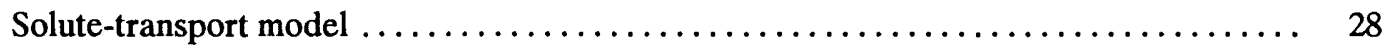

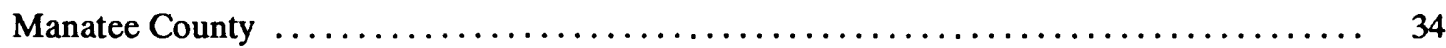

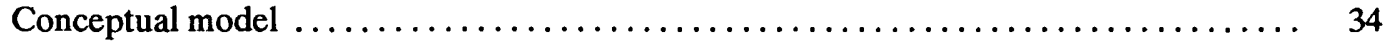

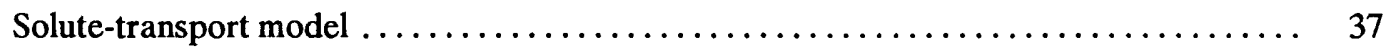

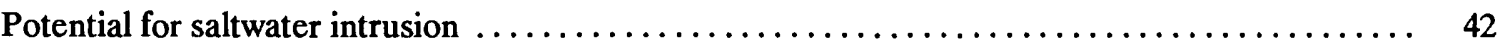

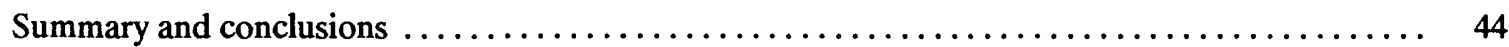

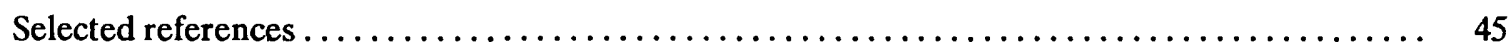

\section{ILLUSTRATIONS}

Figures

1-5. Maps showing:

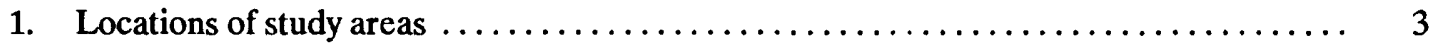

2. Potentiometric surface of the Upper Floridan aquifer prior to development ......... 9

3. Potentiometric surface of the Upper Floridan aquifer, May $1982 \ldots \ldots \ldots \ldots \ldots \ldots \ldots$

4. Potentiometric surface of the Upper Floridan aquifer, September $1982 \ldots \ldots \ldots \ldots \ldots . \quad 12$

5. Chloride concentrations in wells and springs in Hernando and Pasco Counties ...... 14

6-7. Sections showing chloride concentrations in the coastal margin of:

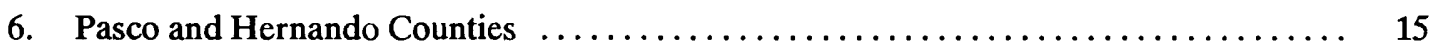

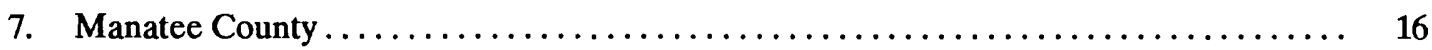




\section{ILLUSTRATIONS}

Figures-Continued

8. Map showing chloride concentrations in wells in Manatee and southern Pinellas

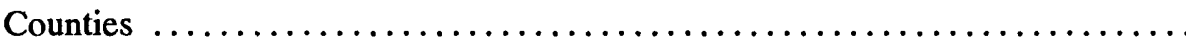

9-10. Geologic columns showing permeable zone, monitored intervals, and specific-conductance distribution at site:

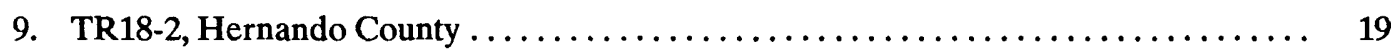

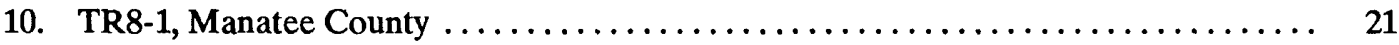

11-13. Graphs showing:

11. Water levels in wells TR18-1 and TR18-2 and tidal fluctuations at Bayport, April 1-10, 1983.

12. Relation between specific conductance in water from well TR18-2, water levels in well TR18-1, and tidal fluctuations at Bayport, March 29 through April 3, 1984 .......

13. Water levels and specific conductance in well TR8-1 and tidal fluctuations

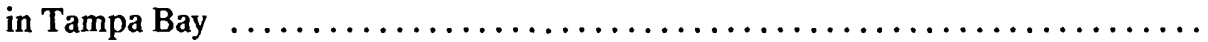

14-18. Sections showing:

14. Hernando County model grid dimensions and matrix properties

15. Modeled steady-state salinity distribution and pore-velocity field in the Upper Floridan

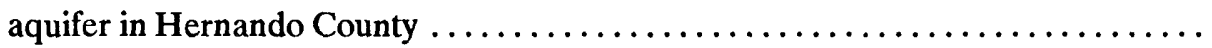

16. Position of the 5-percent seawater-concentration contour due to changes in selected parameters...

17. Position of the 50-percent seawater-concentration contour due to changes in selected

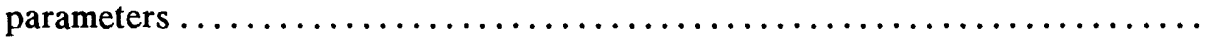

18. Simulated change with time in chloride concentrations as a percent of seawater due to

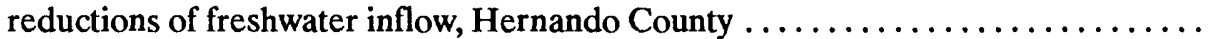

19. Map showing potentiometric surface of the Upper Floridan aquifer in Hernando County and adjacent areas prior to development and after simulation of hypothetical

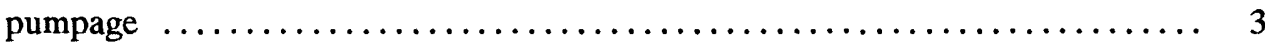

20. Section showing conceptual model of the ground-water flow system, Manatee County . 36

21-23. Sections showing simulated predevelopment positions of the 5-, 50-, and 95-percent seawaterconcentration contours and pore-velocity distribution in the Upper Floridan aquifer:

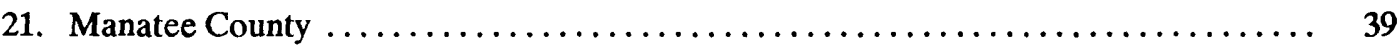

22. With reduced recharge, Manatee County ......................... 40

23. With reduced recharge and permeability changes in inland areas, Manatee County ... 41

\section{TABLES}

1. Generalized hydrogeologic framework for coastal Hernando and Manatee Counties ....... 5

2. Simple ground-water classification for freshwater, brackish water, and saltwater based on dissolved solids and chloride concentrations

3. Chloride-sulfate ratios within two permeable zones in selected wells in Manatee and Pinellas Counties 


\title{
POTENTIAL FOR SALTWATER INTRUSION INTO THE UPPER FLORIDAN AQUIFER, HERNANDO AND MANATEE COUNTIES, FLORIDA
}

\author{
By Gary L. Mahon
}

\begin{abstract}
Pumpage from the Upper Floridan aquifer has caused a lowering of the potentiometric surface and has increased the potential for saltwater intrusion into the aquifer in coastal areas of west-central Florida. Ground-water withdrawals are likely to increase because of the expected population growth, especially in coastal areas. To gain a better understanding of the potential for and mechanisms of saltwater intrusion, two sites were selected for study. Data were collected at each site from a centrally located deep well that completely penetrates the Upper Floridan aquifer. Digital models, based on this and other information, were developed to simulate ground-water flow and solute transport.
\end{abstract}

The northern site is in Hernando County near the town of Aripeka. The test well in the area was drilled about 1 mile from the coast to a depth of 820 feet. Freshwater was present in the carbonate rock aquifer to a depth of about 500 feet, and saltwater occurred in a low permeability zone from 560 feet to the base of the aquifer at about 750 feet. Between the freshwater and saltwater is the zone of transition, also referred to as the freshwater-saltwater interface. At this site, the transition zone is thin and the slope is fairly steep. Aquifer tests indicated that high permeability occurs between 450 and 500 feet, which accounts for a transmissivity of 56,000 feet squared per day.

The southern site is in Manatee County near the town of Rubonia. Drilling of the test well was completed at 1,260 feet, just below the base of the Upper Floridan aquifer. The transition zone in this well occurs between 875 and 975 feet. Transmissivity in the study area was determined to be about 8,500 feet squared per day and is anomalously low, especially in contrast to the transmissivity on the other side of Tampa Bay in Pinellas County. Specific-capacity tests and flowmeter logs indicate that more than 80 percent of the flow comes from the upper 124 feet of uncased well between 462 and 586 feet.

The digital models show flow patterns that are similar to the cyclic flow of seawater and interface theory. Large ground-water withdrawals simulated in the northern study area suggest that saltwater intrusion could cause chloride concentrations to increase in freshwater supply wells in coastal areas, depending upon distance from the shoreline, well depth, and pumping rate. In the southern area, saltwater is present below Manatee County in the lower permeable zone and could migrate farther inland and to upper permeable zones as a result of pumpage for irrigation and mining. The simulations have shown that saltwater contamination of coastal wells would not be noticed as quickly as water-level declines resulting from inland pumpage. Similarly, improvements to water quality in coastal wells will not be apparent as quickly as rising water levels resulting from restoration of ground-water resources.

\section{INTRODUCTION}

Seasonal and long-term ground-water withdrawals from the Floridan aquifer system in west-central Florida for agricultural, industrial, and municipal use have caused a decline in the altitude of the potentiometric surface mostly in the mid- and southern parts of the Southwest Florida Water Management District (SWFWMD). The population within the SWFWMD increased by 15 percent to 2.9 million during the period 1980 to 1985 and is expected to increase to 5.1 million by the year 2020 (Southwest Florida Water Management District, 1984). Population increases have occurred mostly along the coast of the Gulf of Mexico. Consequently, the increase in population will increase the demand for water and stress the ground-water system to a greater extent than at present. Pumpage for public supply within the SWFWMD increased by 13 percent, from 309 to $349 \mathrm{Mgal} / \mathrm{d}$, between 1980 and 1985 due to population increases (Southwest Florida Water Management District, 1984).

Both freshwater and saltwater are present in the ground-water flow system in west-central Florida. The area where these two components meet and mix is called the zone of transition and is commonly designated as the freshwater-saltwater interface. In nature, the interface is not sharp but is an area where the two waters merge gradually. The width of the interface is dependent on the pore characteristics of the aquifer and the magnitude of hydraulic activity.

Increasing the stress on the ground-water system results in a lowering of the potentiometric surface, which, in turn, increases the potential for saltwater intrusion into freshwater aquifers. Saltwater intrusion is a problem in some coastal communities. 
Increases in mineralization of ground water near areas of heavy pumpage, especially in coastal areas, has created concern among water managers and planners. The problem of saltwater intrusion is expected to increase as population rapidly increases and greater demands are placed on the water resources in west-central Florida.

The SWFWMD recognized the need to increase their understanding of the response of the groundwater flow system to increased pumping stress and, in 1976, initiated the Regional Observation and Monitor-Well Program (ROMP). The objective of the program is to construct and maintain long-term ground-water observation wells. Many wells were constructed along transects perpendicular to the gulf coast in the freshwater-saltwater interface to gain a better understanding of the ground-water flow system and the hydrodynamics of seawater motion at the interface in the subsurface. In 1980, the SWFWMD entered into a cooperative agreement with the U.S. Geological Survey to apply the information and resources of the ROMP, to study saltwater intrusion, and to predict movement of highly mineralized water at selected sites under postdevelopment conditions.

The overall objective of the study is to define the coastal ground-water flow systems more clearly. More specifically, the objectives are to: (1) evaluate the application of existing ground-water flow and solute-transport models in cross section to simulate the position of the freshwater-saltwater interface in two areas of west-central Florida characterized by distinctly different hydrologic conditions, and (2) simulate the movement of the saltwater-freshwater interface under various stress conditions using a combination of models and evaluate the effect of movement on inland freshwater sources.

\section{Purpose and Scope}

The purpose of this report is to present the analysis of the hydrogeology and its effect on the potential for saltwater intrusion. Water quality and water levels have been monitored at two coastal well sites and are compared with tidal fluctuations. The comparisons in the report pertain to lag times and dampening effects as a result of the environmental characteristics between the wells and the gulf. Also described, as a result of data collection at the well sites, are analyses supporting flow in the zone of transition based on equations in Hubbert (1969). The report also describes the models that were developed to simulate ground-water flow and the transport of solute in the ground-water flow system. Solute-transport model results are presented that show the position of the freshwater-saltwater interface based on nonunique sets of hydraulic conditions used as input data for the model simulations.

The study area consists of two coastal sites: (1) Aripeka in Hernando County, 40 miles northwest of Tampa; and (2) Rubonia in Manatee County, 25 miles south of Tampa (fig. 1). Each site has a focal point that consists of a ROMP well completed to the base of the Upper Floridan aquifer. Each ROMP well was tested to determine the hydraulic characteristics of the aquifer, logged to determine borehole characteristics and the nature of the freshwater-saltwater transition zone, and finished with several piezometers open to separate zones.

\section{Previous Investigations}

Reichenbaugh (1972) discussed some aspects of saltwater intrusion and defined the freshwatersaltwater interface in the Upper Floridan aquifer in coastal Pasco County. A similar study was done by Mills and Ryder (1977) for a coastal strip north of Pasco County. Hickey (1982) made a detailed study of the saltwater part of the Upper Floridan aquifer in the Pinellas County area to test the feasibility of injecting sewage treatment-plant effluent in saline zones of the aquifer. Wilson (1982) estimated the effects of projected pumpage on movement of the saltwater front in the Upper Floridan aquifer in the southern part of west-central Florida. Steinkampf (1982) discussed the origin and distribution of saline waters in the Upper Floridan aquifer for southwest Florida. Causseaux and Fretwell $(1982 ; 1983)$ updated and expanded earlier studies that defined chloride-concentration distributions and the nature of the freshwater-saltwater interface in west-central Florida. Brown (1982; 1983) made an assessment of the hydrology and water resources in Manatee and Sarasota Counties. CH2M Hill (1982; 1984) prepared reports of their investigations concerning the hydrogeology and practicality of deep well injection in two areas within Manatee County. Fretwell (1985) discussed the water resources and effects of development in Hernando County. Ryder and Mahon (1989) discussed the hydrology of coastal Hernando County and the results of a solute-transport model to represent saltwater intrusion.

\section{DESCRIPTION OF STUDY AREAS}

\section{Hernando County}

The northern site is in Hernando County centered around ROMP well TR18-2, just north of the Pasco 


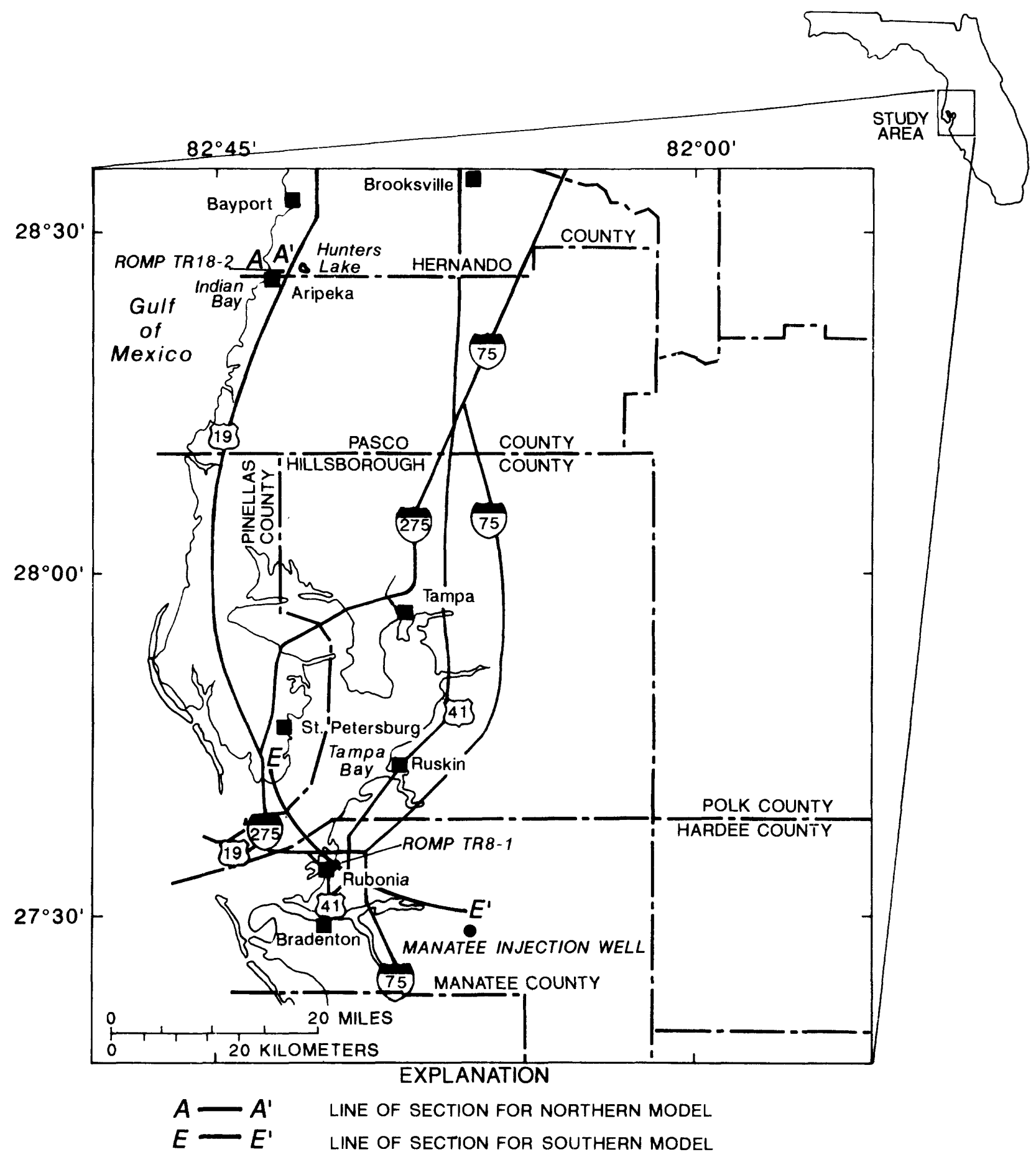

Figure 1.--Locations of study areas. 
County line and east of the town of Aripeka (fig. 1). The area west of U.S. Highway 19 very nearly coincides with the physiographic division known as the Chassahowitzka Coastal Strip (Brooks, 1981). Altitude in this area is generally less than 10 feet above sea level and the area is characterized by limestone occurring at or near the surface with large areas of hardwoods and swamps. Marsh grasses and mangroves occur in the tidal areas near the coast. The area's population is small and centers primarily around Aripeka.

The area east of U.S. Highway 19 lies within the physiographic division known as the Weeki Wachee dunefield. It is characterized by paleontologic sand dunes and solution basins with altitudes less than 90 feet above sea level and covered by sand pine and longleaf turkey oak forests. Hunters Lake, east of U.S. Highway 19, has a surface area of about 350 acres. Residential and commercial development near the lake is proceeding rapidly and resulting in increased demands on the ground-water resources of the area.

Average rainfall for the period 1915 to 1976 at Brooksville, about 15 miles northeast of the study area, was nearly 57 in/yr (Palmer and Bone, 1977). About 50 percent of the rainfall occurs from June through September from thunderstorms and tropical storms (Fretwell, 1985).

\section{Manatee County}

The southern site is centered around ROMP well TR8-1 south of Interstate Highway 275 and west of U.S. Highway 41 near the town of Rubonia in western Manatee County (fig. 1). The site occurs within two physiographic divisions: the Barrier Island Coastal Strip and the De Soto Slope (Brooks, 1981). The coastal strip is bordered by lagoons and islands and is generally less than 20 feet above sea level. A sloping, terraced plain occurs inland from the coastal strip at an altitude of less than 90 feet above sea level. Both areas are vegetated with pines and oaks. The coastal areas also contain mangroves and saltwater marshes, and inland areas contain wet prairies that have drainage systems disrupted by swamps. The area to the north and east has been developed for agriculture with crops of tomatoes, strawberries, and citrus. Surface mining for phosphate occurs to the northeast and east. The mining process at times requires large quantities of water for its operation.

Average rainfall for the period from 1915 to 1976 at Bradenton, about 10 miles southeast of Rubonia, is 54 in/yr (Palmer and Bone, 1977). About 65 percent of this precipitation occurs from June through September.

\section{HYDROGEOLOGIC FRAMEWORK AND HYDRAULIC CHARACTERISTICS}

West-central Florida is underlain by a thick sequence of sedimentary rocks. The hydraulic character of the sediments and the potentiometric surface in each unit control the movement of fresh and saline waters within them. Table 1 shows the stratigraphic and hydrogeologic units and lithology for the sites in Hernando and Manatee Counties. The sequence of rocks has been divided into three principal hydrogeologic units: the surficial aquifer system, the intermediate aquifer system, and the Floridan aquifer system. The Floridan aquifer system includes the Upper Floridan aquifer, middle confining unit, and the Lower Floridan aquifer (Miller, 1986). The carbonate sediments of Tertiary age and younger that compose the Upper Floridan aquifer are of primary interest in this investigation.

Surficial deposits that make up the surficial aquifer system in coastal Hernando County are discontinuous and range in thickness from 0 to 15 feet. The aquifer is comprised of sand, gravel, and clay of Holocene and Pleistocene age. In Manatee County, the surficial deposits are generally less than 25 feet thick and consist of Holocene and Pleistocene sand, sandy limestone, and shell fragments. Probable origins of surficial deposits are marine, estuarine, and alluvial.

Transmissivity of the surficial aquifer system is controlled by the nature of the sediments and their saturated thickness. Surficial aquifer well yields are low in coastal Hernando County, and wells typically do not yield sufficient water to make them economically important. Several shallow wells quickly became dewatered when pumped at rates of less than $5 \mathrm{gal} / \mathrm{min}$ (Fretwell, 1985). Interconnection with the underlying Upper Floridan aquifer varies within the county.

Transmissivity values of the surficial aquifer system in Manatee County range from a little to much greater than those in Hernando County. Transmissivity probably ranges from 100 to $10,000 \mathrm{ft}^{2} / \mathrm{d}$ (Brown, 1983). In western and coastal Manatee County, the transmissivity is most likely within the upper end of this range due to the coarser nature of the sand interbedded with shelly limestone and shell fragments. The base of the surficial aquifer system retards vertical movement of water into and out of the aquifer below. In eastern and central Manatee County, it consists of a hardpan layer of sand and carbonaceous and limonitic material, whereas in 


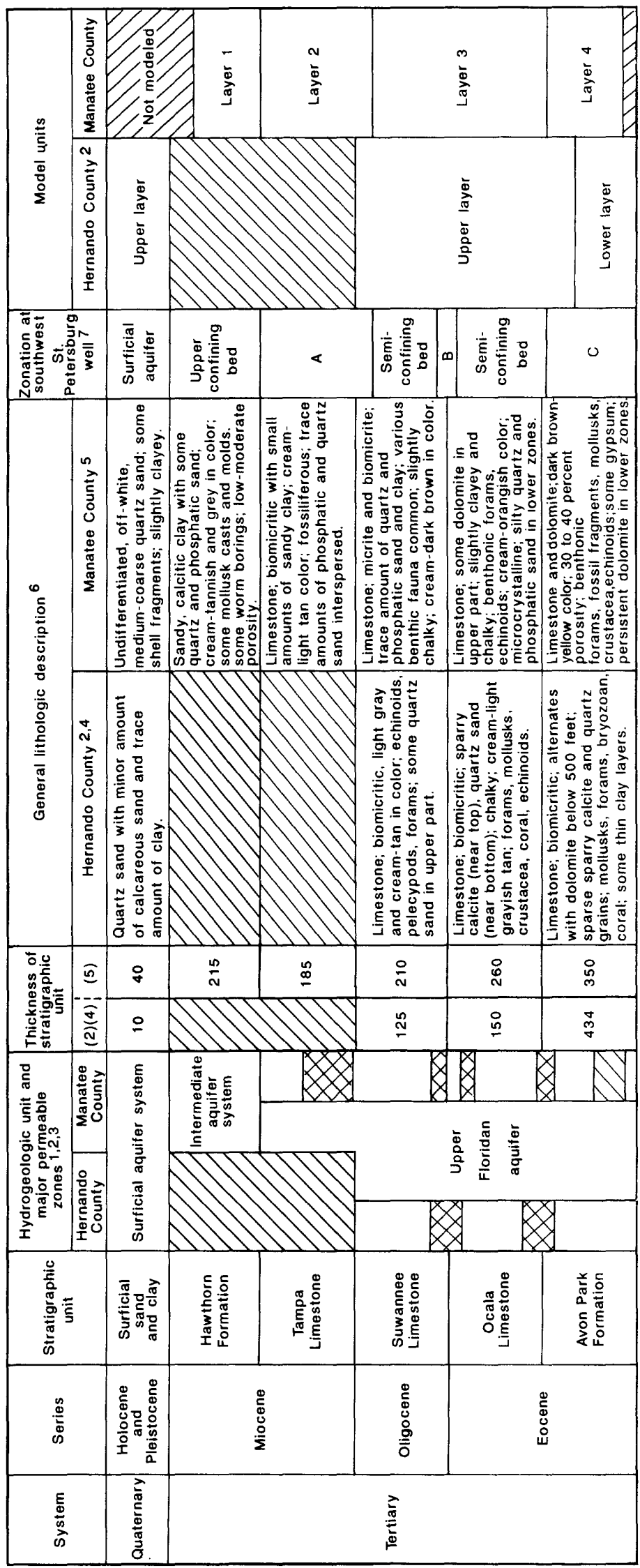

ป⿱艹 
western areas, the base consists of sandy clay, clay, and marl.

Below the surficial aquifer system in Manatee County is the intermediate aquifer system. In the northern part of the county, the system is composed of a single aquifer with confining units above and below, and in the southern part of the county, it consists of one or two aquifers separated by confining units. The aquifer system ranges in thickness from 200 to $\mathbf{3 7 5}$ feet. The confining units consist of sandy clay, clay, and marl that retard the vertical movement of water between the surficial aquifer system and the Upper Floridan aquifer. Near Rubonia, the intermediate aquifer system generally occurs within the upper part of the confining units and is less than 50 feet thick. The aquifer consists of discontinuous beds of quartz and phosphatic sand, gravel, shell, and limestone. The intermediate aquifer and confining units generally occur within the 215 feet of Miocene age sediments of the Hawthorn Formation. The intermediate aquifer system is absent in Hernando County.

Transmissivity values for the intermediate aquifer, based on aquifer tests in southwest Florida, range from less than 1,000 to about $10,000 \mathrm{ft}^{2} / \mathrm{d}$ (Duerr and Wolansky, 1987). In northwestern Manatee County, the intermediate aquifer grades into sediments similar to the confining units and is not easily discernible, from lithologic data, as an aquifer.

Underlying the surficial aquifer system in Hernando County and the intermediate aquifer system in Manatee County is the Upper Floridan aquifer (Miller, 1986). The top of the Upper Floridan aquifer is defined as the top of the vertically persistent carbonate rocks. The Upper Floridan aquifer is composed of a thick sequence consisting of the Tampa Limestone of Miocene age, the Suwannee Limestone of Oligocene age, and the Eocene age sediments of the Ocala Limestone and Avon Park Formation. In coastal Hernando County, the Tampa Limestone is absent. The thickness of the Upper Floridan aquifer is about 800 feet in Hernando County and ranges from about 1,200 to 1,300 feet in Manatee County (Miller, 1982). The base of the Upper Floridan aquifer is defined as the first occurrence of vertically persistent, low permeability, intergranular evaporites, generally within the Avon Park Formation.

The Upper Floridan aquifer is composed of alternate beds of limestone and dolomite that may be discontinuous laterally. The layering and facies changes result in vertical and horizontal permeability variations not necessarily coincidental with formation contacts. Although the aquifer is composed of many discrete lithologic units, on a large scale, it behaves hydraulically as a single unit. However, solutes moving through the aquifer might not follow a generalized, darcian flow path, but might follow permeable pathways.

Sediments overlying the Upper Floridan aquifer affect the vertical movement of water into and out of the aquifer. Leakance to the Upper Floridan aquifer probably ranges from $1 \times 10^{-6}$ to $1 \times 10^{-3}(\mathrm{ft} / \mathrm{d}) / \mathrm{ft}$ (Brown, 1983) based on aquifer tests. Water in the Upper Floridan aquifer moves principally through secondary porosity openings such as joints and fractures enlarged by dissolution of the limestone. In Hernando County, most flow occurs through porous zones at the boundary between the Suwannee and Ocala Limestones and between the Ocala Limestone and the Avon Park Formation. Transmissivity values for the Upper Floridan aquifer in Hernando County have been determined for coastal and inland areas based on aquifer tests and flow-net analysis. In areas around large springs, the transmissivity of the aquifer is generally high, such as at Weeki Wachee Springs ( $\left.>1 \times 10^{6} \mathrm{ft}^{2} / \mathrm{d}\right)$ (Sinclair, 1978). Other estimates of transmissivity range from $9 \times 10^{4}$ to $2.1 \times 10^{6} \mathrm{ft}^{2} / \mathrm{d}$ (Fretwell, 1985).

Hutchinson (1984, fig. 5) reported transmissivity values from flow model simulations to range from 50,000 to $90,000 \mathrm{ft}^{2} / \mathrm{d}$ in the Upper Floridan aquifer for northern coastal Pasco County. Fretwell (1988) extended Hutchinson's (1984) model into Hernando County. Transmissivity values of about $57,000 \mathrm{ft}^{2} / \mathrm{d}$ were applied to the Aripeka area nodes in the Fretwell model (J.D. Fretwell, U.S. Geological Survey, oral commun., 1987).

The hydrogeologic characteristics for the northern site were derived for the present study from hydraulic testing at ROMP well TR18-2. The well had been drilled in 1981 but had not been hydraulically tested before the casing was set to 447 feet. In 1983, ROMP well TR18-2 was deepened to a depth of 820 feet from its original depth of $498 \mathrm{feet}$, and an aquifer test was run on the open-hole interval from 447 to 820 feet. A flowmeter survey was run concurrently during the pumping phase of the test to identify the producing intervals. The flowmeter indicated that nearly all flow was produced from the zone between the bottom of the casing at 447 and 500 feet.

At a test site about 20 miles east-southeast of well TR18-2 in Pasco County, it was determined that the better water-bearing zones are located at formation contacts between the Suwannee and Ocala Limestones and the Ocala Limestone and the Avon 
Park Formation. Major water-bearing zones are in dolomite of the Avon Park Formation at altitudes of 400 feet and 500 feet below sea level (Ryder, 1978, fig. 3). It also was determined at the Pasco County test site that good vertical connection exists between the more permeable zones and that the entire rock column functions as a single aquifer down to the base, which is the first occurrence of intergranular gypsum and anhydrite.

The aquifer test analysis from ROMP well TR18-2 determined a transmissivity of $56,000 \mathrm{ft}^{2} / \mathrm{d}$ (Ryder and Mahon, 1989). Because testing was not performed in the section that was cased, there is uncertainty as to what the transmissivity value actually represents. However, because testing of the Upper Floridan aquifer indicates that the aquifer behaves as a single hydraulic unit, it has been assumed that the value is representative of the upper $\mathbf{5 0 0}$ feet of aquifer. The transmissivity of the lower 235 feet was estimated to be about $500 \mathrm{ft}^{2} / \mathrm{d}$.

The hydrogeology and hydraulic characteristics of the Upper Floridan aquifer in Manatee County are more complex than in Hernando County. In Manatee County, the intermediate aquifer system overlies the Upper Floridan aquifer and affects flow into and out of the aquifer. Hydraulic conductivity variations of one to two orders of magnitude are commonplace, both horizontally and vertically. Transmissivity for the total thickness of the Upper Floridan aquifer ranges from 40,000 to $900,000 \mathrm{ft}^{2} / \mathrm{d}$ (Brown, 1983).

Three main zones of relatively high transmissivity exist in addition to smaller localized zones. The upper zone occurs at the contact between the Tampa Limestone and the overlying confining units in the Hawthorn Formation. This zone underlies most of Manatee County and generally has the highest transmissivity in coastal areas of the county. The upper zone is comparable to zone A (Hickey, 1982) in Pinellas County, which was estimated to have a transmissivity of $29,000 \mathrm{ft}^{2} / \mathrm{d}$. Specific-capacity tests and flowmeter logs of ROMP well TR8-1 indicate that more than 80 percent of the flow in the well comes from the upper 124 feet of uncased well between 462 and 586 feet. Specific-capacity testing determined the transmissivity to be about $8,000 \mathrm{ft}^{2} / \mathrm{d}$ (J.L. Decker, Southwest Florida Water Management District, written commun., 1984). In inland areas of Manatee County, the thickness and transmissivity of the upper zone decrease, and the zone yields less water than the middle and lower major permeable zones.
The middle zone occurs within the Suwannee and Ocala Limestones and is comprised of thinner beds of permeable rock than zones above and below. The most permeable rock occurs near the contacts between the Tampa and Suwannee Limestones and between the Suwannee and Ocala Limestones. Transmissivity of the middle zone in Pinellas County is less than in the upper zone but is about $17,000 \mathrm{ft}^{2} / \mathrm{d}$ in central Manatee County (CH2M Hill, 1982). The permeable units within the middle zone are equivalent to zone B (Hickey, 1982) in Pinellas County. Below the middle zone is the Ocala Limestone that acts as a semiconfining unit between the lower and middle zones.

The fractured dolomites of the Avon Park Formation comprise the lowermost major permeable zone within the Upper Floridan aquifer. Most production inland in the county comes from this zone, and water managers are concerned about the potential for intrusion of seawater into the zone. There have been few transmissivity determinations for the lower zone in Manatee County.

William F. Guyton and Associates (1976) determined the transmissivity about 25 miles eastnortheast of Rubonia to be from 100,000 to $135,000 \mathrm{ft}^{2} / \mathrm{d}$. Transmissivity about 10 miles from Rubonia in southern Manatee County was determined to be about $15,000 \mathrm{ft}^{2} / \mathrm{d}$ (CH2M Hill, 1984). Across Tampa Bay in Pinellas County, transmissivity values have been reported in excess of $1 \times 10^{6} \mathrm{ft}^{2} / \mathrm{d}$ (Hickey, 1982). Specific-capacity testing determined transmissivity of the lower zone in the vicinity of the Rubonia well TR8-1 to be about $900 \mathrm{ft}^{2} / \mathrm{d}$ (J.L. Decker, Southwest Florida Water Management District, written commun., 1984).

The less transmissive rocks between the three major permeable zones generally act as semiconfining units, retarding vertical movement of water between the zones. The hydraulic conductivity of the semiconfining material is typically $2 \mathrm{ft} / \mathrm{d}$ (Hickey, 1982) in Pinellas County. Beneath the Avon Park dolomite zone and above the evaporites of the middle confining unit is a zone with low transmissivity. The hydraulic conductivity of this semiconfining zone is also estimated to be $2 \mathrm{ft} / \mathrm{d}$ based on laboratory tests and aquifer testing at southwest St. Petersburg (Hickey, 1982; J.J. Hickey, U.S. Geological Survey, oral commun., 1982). 


\section{GROUND-WATER FLOW SYSTEM IN THE UPPER FLORIDAN AQUIFER}

\section{Predevelopment Potentiometric Surface, Recharge, and Discharge}

Predevelopment hydrologic conditions are considered to be those conditions that existed prior to man's influence on the system. Predevelopment potentiometric-surface levels (Johnston and others, 1980) indicate that, generally, freshwater recharged the ground-water system in inland areas and flowed toward the coast where freshwater discharged through springs or through diffuse upward leakage (fig. 2). Ground water in coastal Hernando County flowed from a closed high in the potentiometric surface of the Upper Floridan aquifer 25 miles eastsoutheast of Aripeka. Predevelopment water levels in coastal areas were generally less than $\mathbf{1 0}$ feet above sea level. Ground water in coastal Manatee County flowed from a closed potentiometric-surface high 70 miles to the northeast along a 90-mile curved flow path before reaching the coast at Tampa Bay (fig. 2). The altitude of the potentiometric surface in Manatee County ranged from more than 60 feet inland to about 25 feet near Tampa Bay and from 5 to 10 feet in peninsular Pinellas County.

Recharge occurred either directly into the Upper Floridan aquifer or by downward percolation of water through overlying semiconfining units. Principal recharge areas for the Upper Floridan aquifer in west-central Florida were in northeastern Hillsborough and northern Polk Counties and central Hernando and northern and central Pasco Counties (Ryder, 1985, p. 1). The high recharge there generally is associated with sand ridge areas. In both areas, the intermediate aquifer system is generally absent due to erosion, and the Upper Floridan aquifer is recharged directly by downward percolation through the surficial aquifer system.

In Hernando County, recharge occurs as downward infiltration of rainfall through the surficial aquifer system and runoff to closed depressions and sinkholes. Generally, recharge areas are east of U.S. Highway 19. Annual recharge rates to the Upper Floridan aquifer were estimated by a regional flow model (Ryder, 1982, fig. 16) to be from 10 to 20 inches. In coastal Manatee County, the potentiometric surface for the Upper Floridan aquifer is considered to have been higher than the predevelopment potentiometric surface of the intermediate aquifer. Consequently, flow was upward from the Upper Floridan aquifer to the overlying aquifers under predevelopment conditions.
Natural discharge from the Upper Floridan aquifer occurs as vertical flow across the overlying confining layer or as discharge to springs. In Hernando County, discharge areas generally occur west of U.S. Highway 19 where water moves vertically upward to discharge as springs or as diffuse upward leakage to low-lying, coastal swamps. A crosssectional digital flow model developed to simulate flow along section line $\mathrm{A}-\mathrm{A}^{\prime}$ (fig. 1) indicates an average upward leakage rate of about $30 \mathrm{in} / \mathrm{yr}$ (Ryder and Mahon, 1989). Greatest discharge rates occur at springs near the gulf. Only about 10 percent of the upward flow occurs as diffuse upward leakage in coastal marshes and estuaries (Yobbi, 1989).

There are no springs in coastal Manatee County and natural discharge occurs only as diffuse upward leakage across the confining bed of the intermediate aquifer system. Discharge rates, reported from a regional flow model (Ryder, 1982, fig. 16), range from 0.1 to $1.0 \mathrm{in} / \mathrm{yr}$ in western Manatee County and increase beneath Tampa Bay. Transfer of water between the Upper Floridan aquifer and Tampa Bay is dependent on differences between sea level and the aquifer's hydraulic head and on the thickness and hydraulic characteristics of the confining unit between Tampa Bay and the Upper Floridan aquifer. Under the bay, poorly yielding strata of the intermediate confining unit are thinner than in inland Manatee County, allowing more water to leave the Upper Floridan aquifer's flow system than in inland areas.

Downward migration of saltwater is associated with the discharge from the Upper Floridan aquifer in coastal areas. The saltwater entering the flow system is more dense than the freshwater and, consequently, flows beneath the freshwater. The opposing flow directions of the freshwater and saltwater are part of a convective flow system that develops in the transition zone and will be described later. In Hernando County, the entrance of saltwater into the aquifer occurs seaward of the coast from the Gulf of Mexico. Saltwater in deep zones beneath Manatee County enters the aquifer from the gulf and flows beneath Tampa Bay.

\section{Effect of Water-Resource Development}

The potentiometric surface in coastal Hernando County has not changed substantially as a result of ground-water development. Water levels have declined slightly, but the general flow pattern has been retained (figs. 3 and 4). In Manatee County, pumping for agriculture and mining has caused a lowering of the predevelopment surface (Yobbi, 


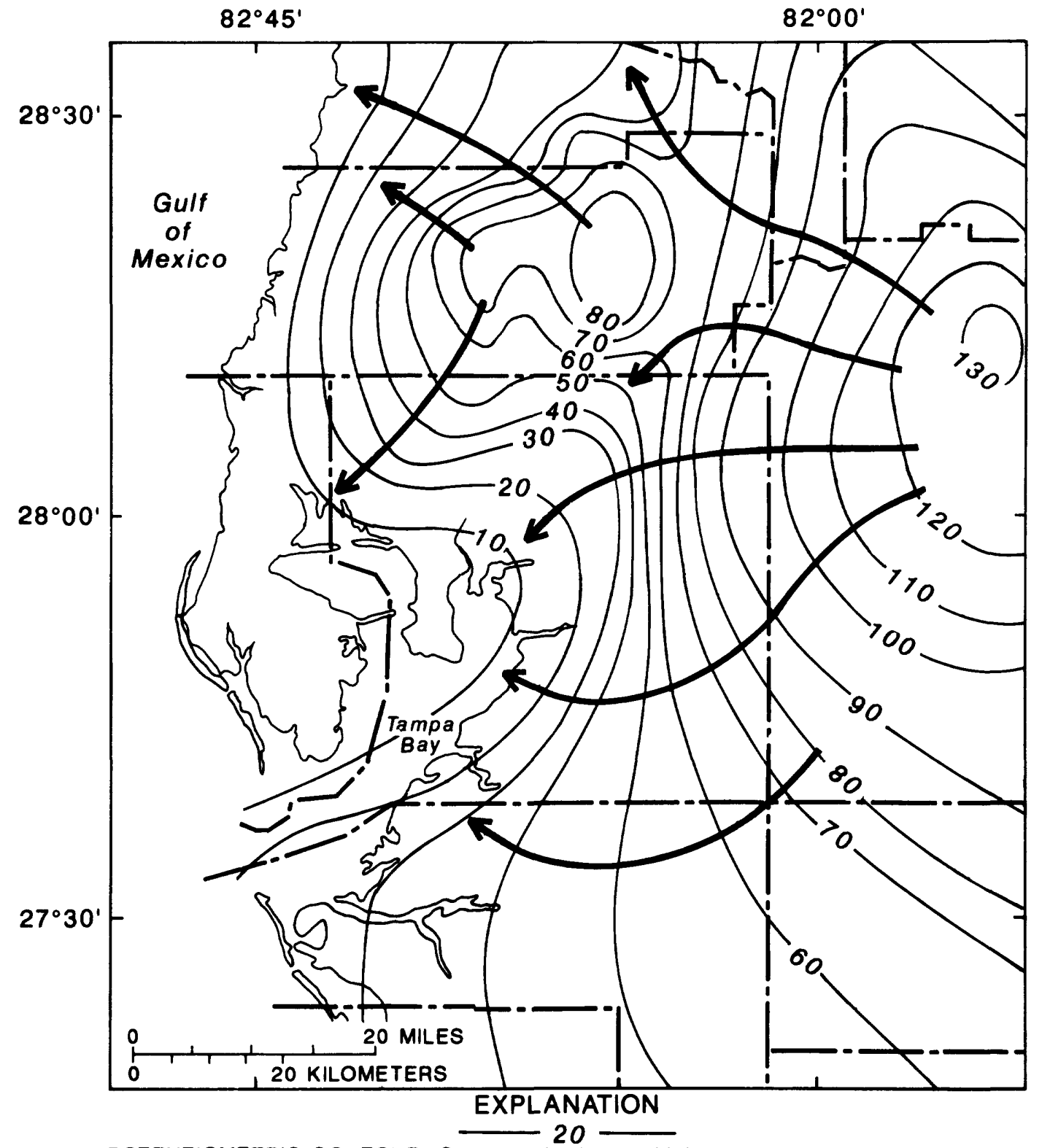

POTENTIOMETRIC CONTOUR--Shows altitude at which water level would have stood in tightly cased wells. Contour interval 10 feet. Datum is sea level

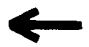

FLOW PATH--Arrow indicates direction of regional ground-water flow

Figure 2. - Potentiometric surface of the Upper Floridan aquifer prior to development. (Modified from Johnston and others, 1980.) 
1983). Seasonal ground-water withdrawal for irrigation causes depressions in the potentiometric surface in coastal areas to levels below sea level near the end of the dry season. These depressions have resulted in changes in the flow pattern and have, in some areas, caused temporary reversals in the direction of ground-water flow.

Figures 3 and 4 show the potentiometric surface of the Upper Floridan aquifer for May and September 1982, respectively. Compared to predevelopment conditions, flow beneath Hernando County was still coastward, but the contours have shifted landward because of pumpage that reduced the potentiometric surface. In Manatee County, the configuration of the potentiometric surface has changed since predevelopment and also changes considerably between May and September. In May, the configuration of the potentiometric surface had changed as a result of a decline in precipitation and increases in agricultural pumpage. Consequently, less water is recharged to the aquifer and greater amounts are withdrawn. The net effects, as shown in the central part of the county (fig. 3), are depressions in the potentiometric surface and a resulting change in the flow pattern. In September, the Upper Floridan aquifer is generally near its highest potentiometric levels as a result of the wet season and corresponding reduction of agricultural pumpage in the summer. The shape of the potentiometric surface is similar to the predevelopment surface, but the levels are lower, and consequently, the flow rate toward the coast, which is head dependent, is reduced.

Saltwater is present in the aquifer as a wedge extending beneath the freshwater in most coastal areas. As heads change inland due to fluctuations of the potentiometric surface or reversals in the potentiometric gradient, the saltwater will move in response to the new conditions. Induced leakage from overlying aquifers and semiconfining beds also occurs as a response to decreased heads in the Upper Floridan aquifer. When the heads decline below sea level near Tampa Bay, saline water can move through the semiconfining beds toward the aquifer.

\section{WATER QUALITY IN THE UPPER FLORIDAN AQUIFER}

The quality of water within the rocks comprising the Upper Floridan aquifer in west-central Florida is largely controlled by the dissolution of minerals as water flows from recharge areas toward the coast. In coastal areas, saline water is mixed with freshwater within the aquifer, resulting in higher concentrations of some dissolved constituents. The extent of inland migration of highly mineralized water is dependent on the natural hydrogeologic conditions and man's alteration of the natural conditions.

Water within the Upper Floridan aquifer is generally more mineralized than water from the surficial and intermediate aquifer systems. Dissolved-solids concentrations vary both vertically and areally in both study areas. Concentrations generally increase with depth and are highest near the coast.

\section{Water Quality In Hernando County}

Specific values of some parameters used to define freshwater and saltwater vary between reports. Values used in this report to define freshwater, brackish water, and saltwater are given in table 2 . Brackish water has chemical properties that are transitional between freshwater and saltwater and is, consequently, found in the transition zone. In Hernando County, freshwater occurs throughout the total thickness of the Upper Floridan aquifer except

Table 2. - Simple ground-water classification for freshwater, brackish water, and saltwater based on dissolved solids and chloride concentrations

[mg/L, milligrams per liter; $\mu \mathrm{S} / \mathrm{cm}$, microsiemens per centimeter]

\begin{tabular}{lcccc}
\hline \multicolumn{1}{c}{ Category } & $\begin{array}{c}\text { Dissolved } \\
\text { solids } \\
(\mathrm{mg} / \mathrm{L})\end{array}$ & $\begin{array}{c}\text { Chloride } \\
\text { concen- } \\
\text { tration } \\
(\mathrm{mg} / \mathrm{L})\end{array}$ & $\begin{array}{c}\text { Fluid } \\
\text { specific } \\
\text { conductance } \\
(\mu \mathrm{S} / \mathrm{cm})\end{array}$ \\
\hline Freshwater & $0-1,500$ & $0-500$ & $0-1,500$ \\
Brackish water & $1,000-10,000$ & $\frac{\text { Approximate }}{\text { Equivalent }}$ & $500-5,000$ & $1,500-15,000$ \\
Saltwater & $10,000-100,000$ & & $5,000-50,000$ & $15,000-150,000$ \\
\hline
\end{tabular}




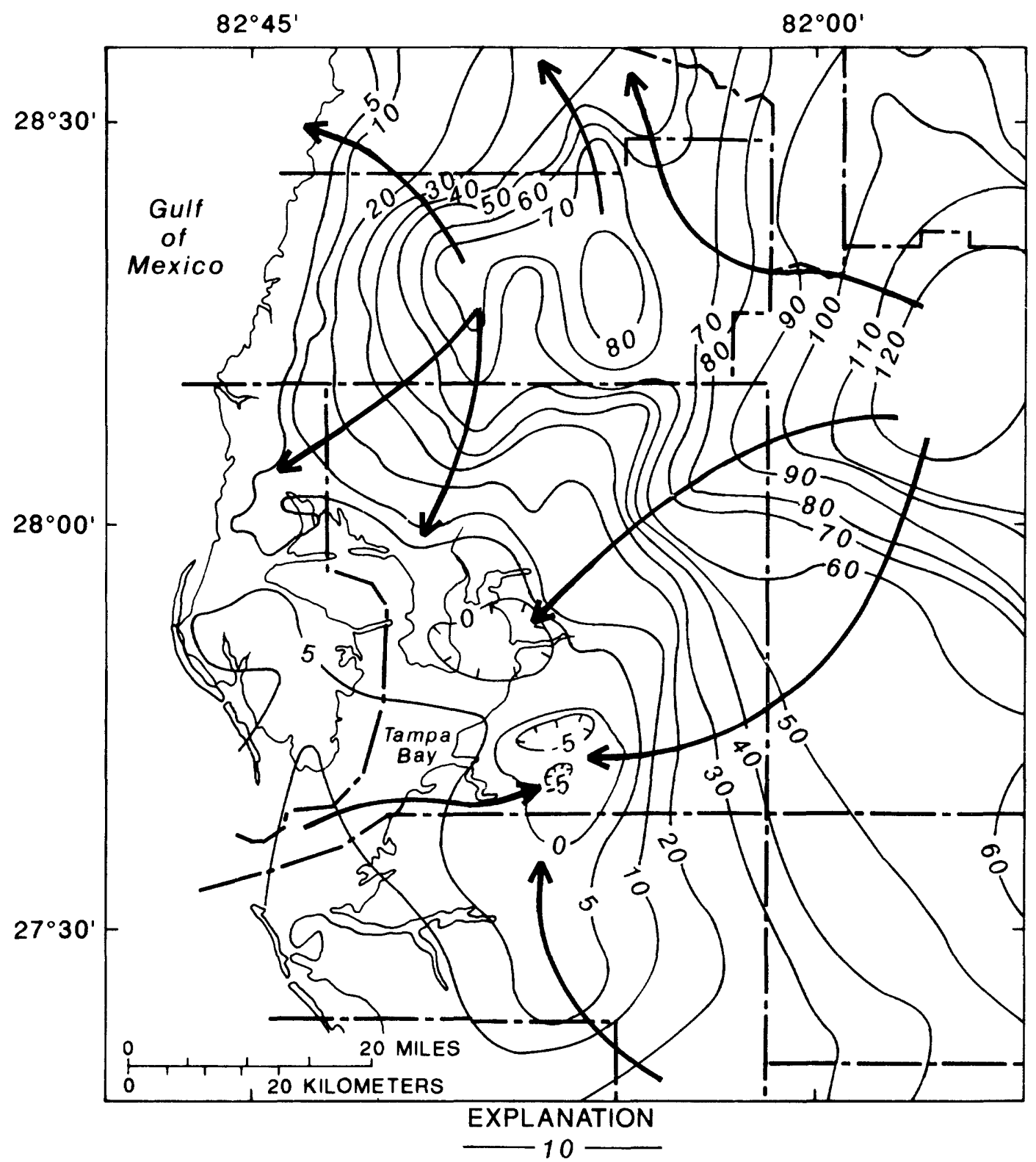

POTENTIOMETRIC CONTOUR--Shows altitude at which water level would have stood in tightly cased wells. Contour interval 5 and 10 feet. Datum is sea level

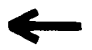

FLOW PATH--Arrow indicates direction of regional ground-water flow

Figure 3. - Potentiometric surface of the Upper Floridan aquifer, May 1982. (Modified from Barr and Schiner, 1982a.) 


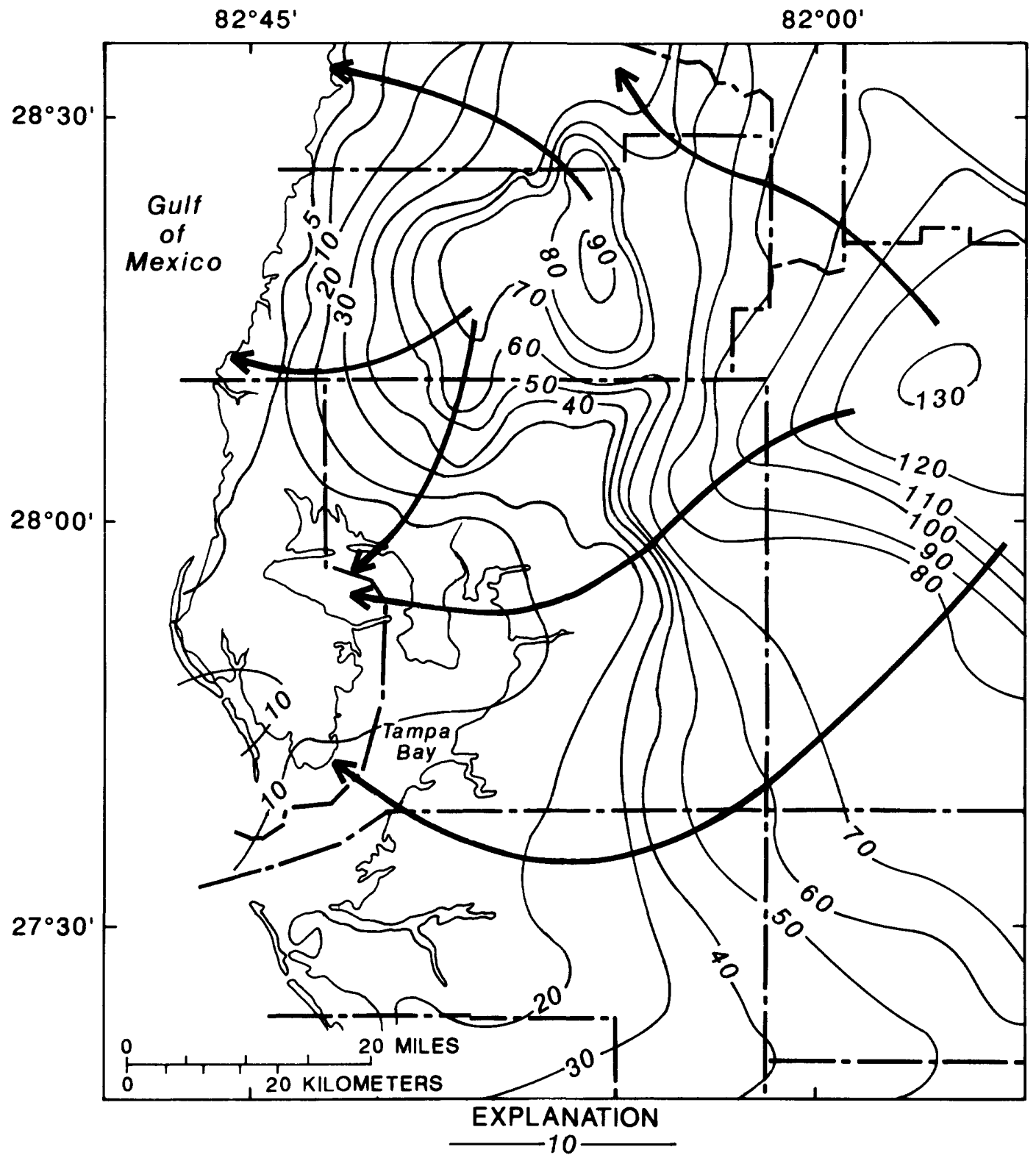

POTENTIOMETRIC CONTOUR--Shows altitude at which water level would have stood in tightly cased wells. Contour interval 5 and 10 feet. Datum is sea level

FLOW PATH--Arrow indicates direction of regional ground-water flow

Figure 4. - Potentiometric surface of the Upper Floridan aquifer, September 1982.

(Modified from Barr and Schiner, 1982b.) 
within 1 to 2 miles of the coast where intruding seawater increases the chloride concentration of the ground water. Saltwater generally is encountered at greater depths away from the coast than near the coast forming a wedge or a series of wedges where saltwater occurs beneath freshwater.

Water samples were collected in coastal Hernando and Pasco Counties (fig. 5) to define the freshwatersaltwater interface within the Upper Floridan aquifer (Mills and Ryder, 1977). Samples were collected from wells open to various zones and from springs discharging from the Upper Floridan aquifer. Except for those taken near the coast or from a deep zone, many samples had chloride concentrations of less than $30 \mathrm{mg} / \mathrm{L}$. The exceptions are wells 7 and 8 that are relatively shallow and adjacent to saltwater channels, three wells $(11,12$, and 13) in Pasco County that are at the coast, and two of the nested wells at ROMP TR18-2 whose screens were placed below the zone of transition between freshwater and saltwater. Chloride concentration in well 7 varied between measurements in 1965 and 1975, probably because of tidal fluctuations in the Gulf of Mexico. Maximum chloride concentration generally does not exceed $19,000 \mathrm{mg} / \mathrm{L}$, which is the concentration expected for seawater (Hem, 1985, p. 7, table 2).

Water samples taken at Boat Spring had fairly low dissolved chloride concentrations $(12-21 \mathrm{mg} / \mathrm{L})$ even though the spring is only a few hundred feet from an estuary open to the Gulf of Mexico. It is possible, however, that these samples were taken at low tide when seawater had slightly retreated from the Upper Floridan aquifer, resulting in discharge of fresher water. Sampling during high tide might show higher chloride concentrations, which indicates a mixing of freshwater and saltwater. It is also possible that these springs are part of a relatively shallow flow system of connected conduits, and these solution channels are carrying fresher water than water in wells open to less permeable rocks (Ryder, 1985).

Causseaux and Fretwell (1983) constructed cross sections, including three in Hernando and Pasco Counties, to show the regional distribution of chloride using chloride concentrations for wells within 2 miles of a line of section. Chloride concentrations are shown in figure 6 for the bottom altitude of each well. Section D-D' (fig. 6) was constructed using data from the ROMP TR18-2 test site and other wells within 1 mile of the line of section.

The slope and width of the freshwater-saltwater interface varies between the lines of section. Compared to section D-D', the shape and position of the interface in section B-B' near Weeki Wachee
Springs may be explained by freshwater discharging through the large springs. Consequently, the lower hydraulic head for a given distance from the coast allows for higher chloride concentrations at shallow depths.

The difference between the interface orientation in section C-C' and D-D' is less clear. The areas represented by these cross sections are very similar in their topographic and hydrogeologic conditions and relation of hydraulic head to distance from the coast. It is possible that the difference in the slope of the interface is a result of variations in hydraulic properties of aquifer or possibly increasing groundwater development in Pasco County. The dredging of finger canals in coastal areas, a large rock-quarrying operation, and ground-water withdrawals ranging from 4.0 to $11.1 \mathrm{Mgal} / \mathrm{d}$ for municipal and rural use (Duerr and Sohm, 1983) may have altered the chloride-concentration distribution in the subsurface.

\section{Water Quality in Manatee County}

Background chloride concentrations of freshwater in Manatee County range from 25 to $50 \mathrm{mg} / \mathrm{L}$. Causseaux and Fretwell (1983, fig. 11, H-H' and I-I') show the distribution of chlorides in cross section for the Upper Floridan aquifer above the Avon Park permeable zone (fig. 7). Chloride data that are shown in figure 8 were collected in May and September 1986 from available wells in coastal areas. The data agree well with those data compiled by Causseaux and Fretwell (1983). Wells in the area typically penetrate the permeable zones of the Tampa and Suwannee Limestones and are uncased throughout a large section. Chloride concentrations of samples taken from these wells may be diluted but are probably representative of flow from the most highly permeable zone in the well bore. Consequently, samples are representative of a large percentage of the flow into the well. Few wells near the coast penetrate the Avon Park permeable zone.

Sulfate concentration in the Upper Floridan aquifer in Manatee County is generally high and increases with depth and toward the coast. Concentrations range from less than $5 \mathrm{mg} / \mathrm{L}$ to about $900 \mathrm{mg} / \mathrm{L}$ (Brown, 1983). In the upper permeable zone, sulfate concentrations of more than $250 \mathrm{mg} / \mathrm{L}$ only occur in coastal regions. High sulfate concentrations (exceeding $250 \mathrm{mg} / \mathrm{L}$ ) occur landward of coastal regions in both the middle and lower permeable zones. 


\begin{tabular}{|c|c|c|c|c|}
\hline Well number & $\begin{array}{c}\text { Date } \\
\text { (month/year) }\end{array}$ & $\begin{array}{c}\text { Well } \\
\text { depth } \\
\text { (feet) }\end{array}$ & $\begin{array}{l}\text { Casing } \\
\text { depth } \\
\text { (feet) }\end{array}$ & $\begin{array}{c}\text { Chloride } \\
\text { concentration } \\
\text { (milligrams } \\
\text { per liter) }\end{array}$ \\
\hline $\begin{array}{lc} & 1 \\
& 2 \\
& 3 \\
& 4 \\
& 5 \\
& 6 \\
& 7 \\
\text { Metered } & \\
\text { wells at } & 8 \\
\text { site TR18-2 } & \left\{\begin{array}{c}9 \mathrm{a} \\
9 \mathrm{~b} \\
\end{array}\right. \\
& 10 \\
& 10 \\
& 11 \\
& 12 \\
13\end{array}$ & $\begin{array}{c}12 / 75 \\
12 / 75 \\
12 / 75 \\
9 / 81 \\
12 / 75 \\
12 / 75 \\
10 / 65 \\
11 / 75 \\
8 / 84 \\
6 / 84 \\
5 / 84 \\
6 / 84 \\
12 / 75 \\
(?) \\
(?) \\
9 / 78\end{array}$ & $\begin{array}{c}- \\
180 \\
170 \\
580 \\
373 \\
101 \\
195 \\
\\
70 \\
480 \\
547 \\
800 \\
250 \\
73 \\
100 \\
111\end{array}$ & $\begin{array}{c}- \\
- \\
- \\
445 \\
210 \\
64 \\
176 \\
\\
51 \\
447 \\
505 \\
750 \\
81 \\
- \\
- \\
-\end{array}$ & $\begin{array}{c}5 \\
30 \\
7 \\
5 \\
6 \\
17 \\
13,600 \\
18,000 \\
8,200 \\
3 \\
10,000 \\
18,200 \\
2 \\
254 \\
35 \\
50\end{array}$ \\
\hline Spring(s) & $\begin{array}{c}\text { Date } \\
\text { (month/year) }\end{array}$ & \multicolumn{2}{|c|}{$\begin{array}{c}\text { Discharge } \\
\text { (million } \\
\text { gallons per } \\
\text { day) }\end{array}$} & $\begin{array}{c}\text { Chloride } \\
\text { concentration } \\
\text { (milligrams } \\
\text { per liter) }\end{array}$ \\
\hline $\begin{array}{l}\text { Bobhill } \\
\text { Boat }\end{array}$ & $\begin{array}{r}11 / 64 \\
8 / 65 \\
12 / 72 \\
2 / 62 \\
5 / 62 \\
4 / 64 \\
10 / 64\end{array}$ & & & $\begin{array}{r}5 \\
4 \\
8 \\
- \\
21 \\
- \\
12\end{array}$ \\
\hline
\end{tabular}

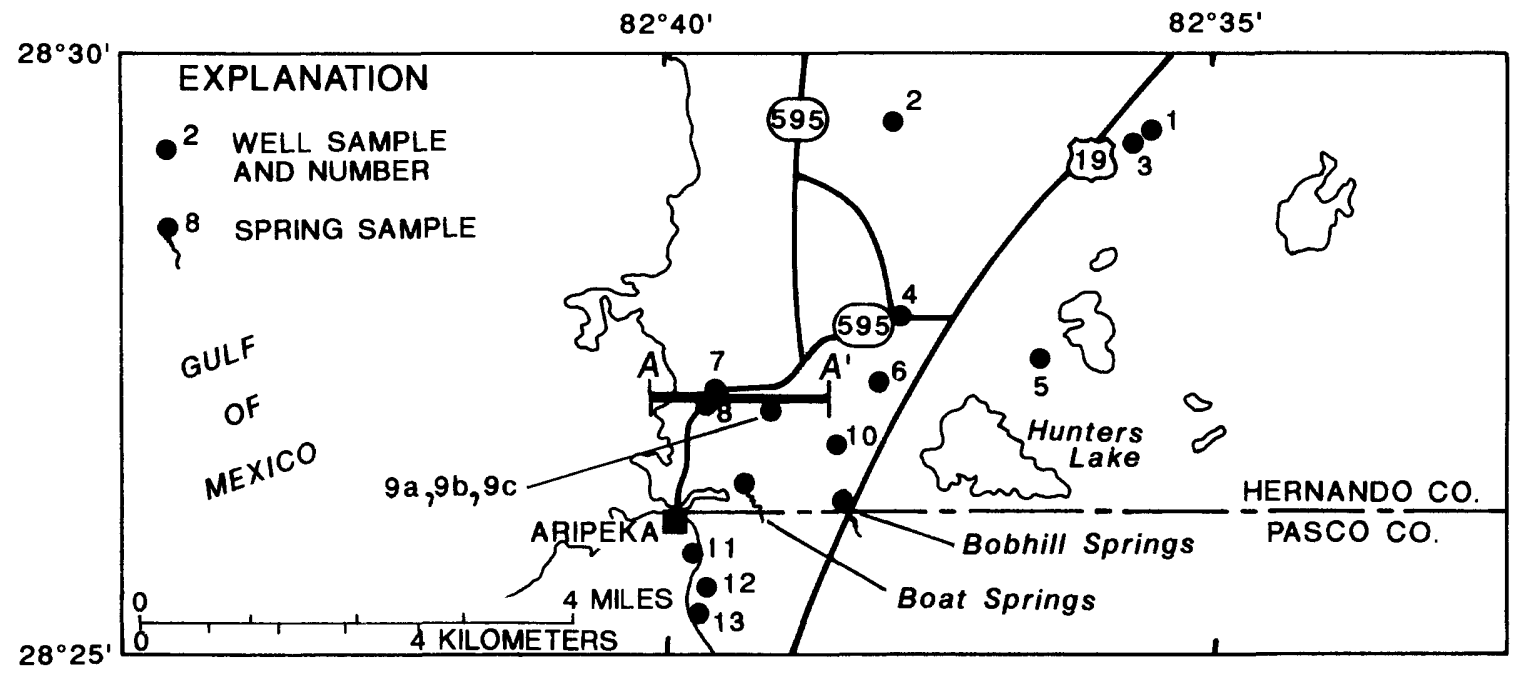

Figure 5. - Chloride concentrations in wells and springs in Hernando and Pasco Counties.

(Modified from Mills and Ryder, 1977.) 


\section{EXPLANATION}

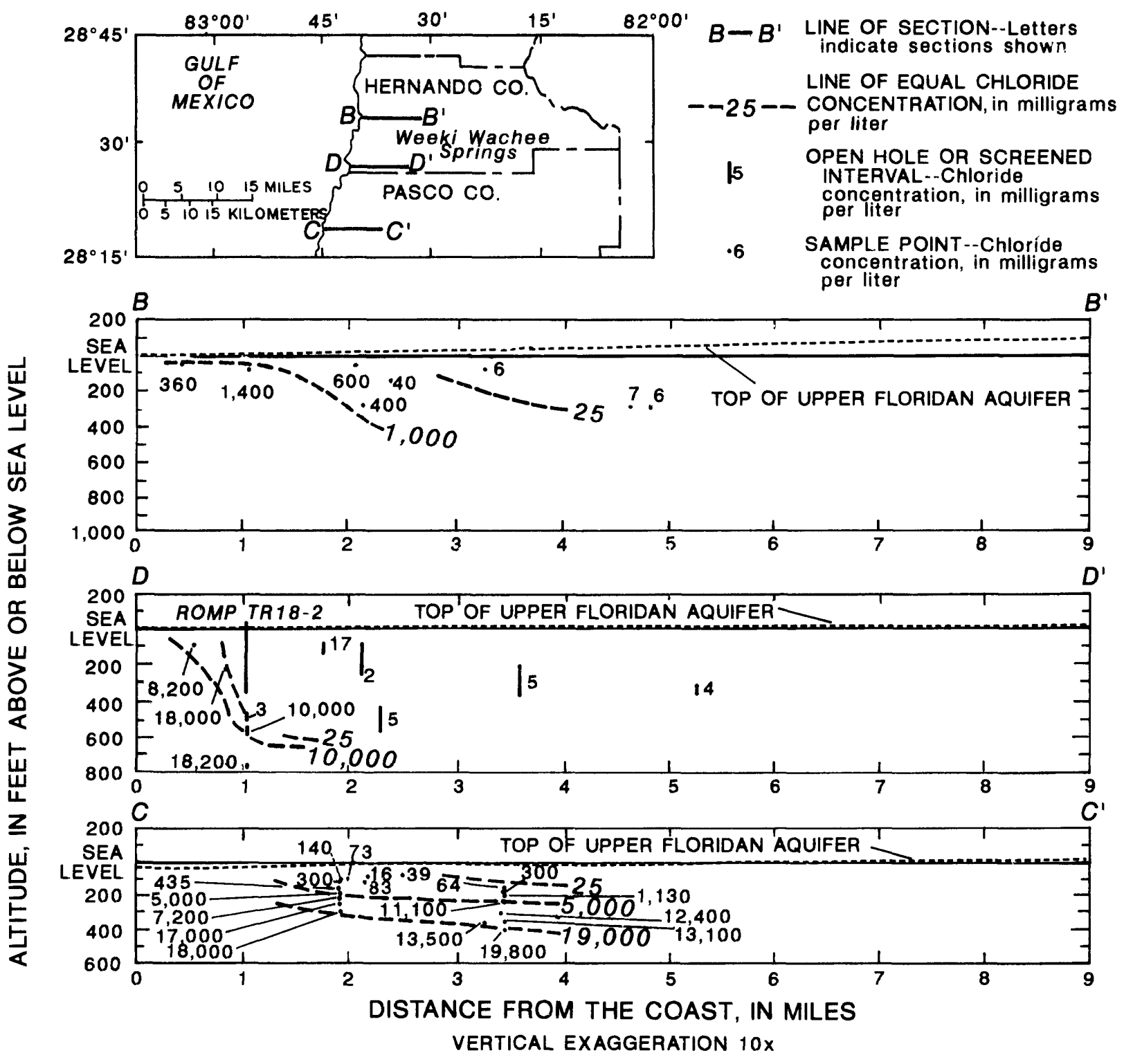

Figure 6. - Chloride concentrations in the coastal margin of Pasco and Hernando Counties.

(Modified from Causseaux and Fretwell, 1983.) 


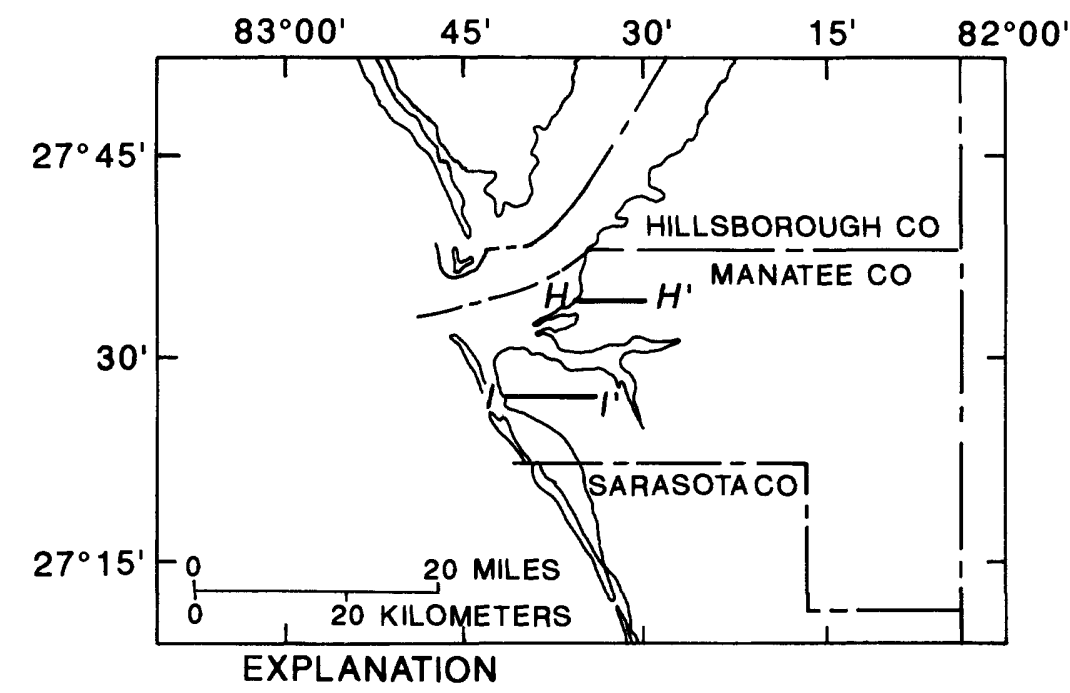

$H-H^{\prime}$ LINE OF SECTION--Letters indicate sections shown

- 25-- LINE OF EQUAL CHLORIDE CONCENTRATION, in milligrams per liter

.217 SAMPLE POINT--Chloride concentration, in milligrams per liter

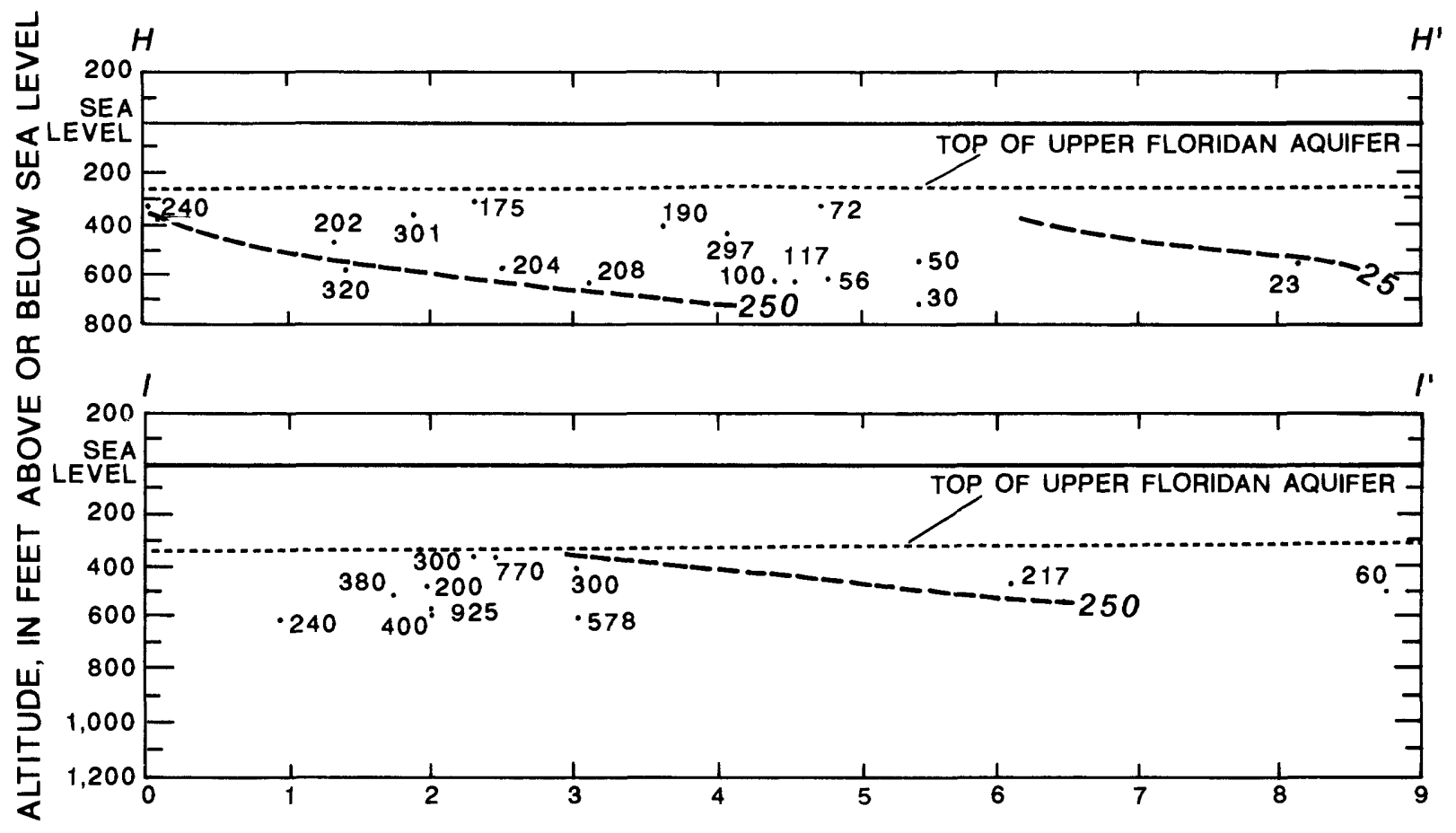

DISTANCE FROM THE COAST, IN MILES VERTICAL EXAGGERATION 10X

Figure 7. - Chloride concentrations in the coastal margin of Manatee County.

(Modified from Causseaux and Fretwell, 1983.) 


\begin{tabular}{|c|c|c|c|c|c|c|c|}
\hline $\begin{array}{c}\begin{array}{c}\text { Well } \\
\text { number }\end{array} \\
\end{array}$ & Date & $\begin{array}{r}\text { Casing } \\
\text { depth } \\
\text { (foet) }\end{array}$ & $\begin{array}{l}\text { Total } \\
\text { depth } \\
\text { (feet) }\end{array}$ & $\begin{array}{c}\text { Specific } \\
\text { conductance } \\
(\mu \mathrm{S} / \mathrm{cm})\end{array}$ & $\begin{array}{l}\text { Chloride } \\
\text { (mg/L) }\end{array}$ & $\begin{array}{l}\text { Sulfate } \\
(\mathrm{mg} / \mathrm{L})\end{array}$ & $\begin{array}{c}\text { Hydro- } \\
\text { geologic } \\
\text { zone }\end{array}$ \\
\hline 1 & $\begin{array}{l}5-20-86 \\
9-29-86\end{array}$ & 44 & 460 & $\begin{array}{l}1,970 \\
1,950\end{array}$ & $\begin{array}{l}240 \\
240\end{array}$ & & \\
\hline 3 & $5-22-86$ & 142 & 405 & 1,420 & 130 & & \\
\hline 9 & $5-22-86$ & 57 & 350 & 1,030 & 64 & & \\
\hline 13 & $5-23-86$ & 276 & 453 & 805 & 25 & & Upper permeable \\
\hline 18 & $\begin{array}{l}5-20-86 \\
9-29-86\end{array}$ & 63 & 385 & $\begin{array}{l}2,830 \\
2,800\end{array}$ & $\begin{array}{l}510 \\
510\end{array}$ & & Upper permeable \\
\hline 19 & $\begin{array}{l}5-22-86 \\
9-29-86\end{array}$ & 65 & 416 & $\begin{array}{l}2,580 \\
2,469\end{array}$ & $\begin{array}{l}390 \\
369\end{array}$ & & Upper permeabe \\
\hline 21 & $\begin{array}{l}5-22-86 \\
9-29-86\end{array}$ & 202 & 600 & $\begin{array}{l}2,410 \\
2,389\end{array}$ & $\begin{array}{l}300 \\
309\end{array}$ & & Upper permeable \\
\hline 39 & $5-23-86$ & 90 & 926 & 1,980 & 330 & & \\
\hline 66 & $\begin{array}{l}5-20-86 \\
9-29-86\end{array}$ & 200 & 525 & $\begin{array}{l}2,090 \\
2,130\end{array}$ & $\begin{array}{l}240 \\
250\end{array}$ & & Upper permeable \\
\hline 68 & $\begin{array}{l}5-20-86 \\
9-29-86\end{array}$ & 18 & 450 & $\begin{array}{l}1,920 \\
1,920\end{array}$ & $\begin{array}{l}240 \\
240\end{array}$ & & Upper permeable \\
\hline TR8-1 & $\begin{array}{l}5-31-84 \\
8-20-86 \\
4-05-87\end{array}$ & $\begin{array}{r}462 \\
900 \\
1,130\end{array}$ & $\begin{array}{l}800 \\
940\end{array}$ & $\begin{array}{r}1,120 \\
4,500 \\
47,800\end{array}$ & $\begin{array}{r}59 \\
1,100 \\
18,875\end{array}$ & $\begin{array}{r}410 \\
544 \\
3,303\end{array}$ & $\begin{array}{l}\text { Lower permeable } \\
\text { Lower permeabe }\end{array}$ \\
\hline $\begin{array}{l}\text { Southwest } \\
\text { St. Petersburg } \\
\text { injection site }\end{array}$ & $\begin{array}{ll}\text { 6- } & -77 \\
6- & -77\end{array}$ & $\begin{array}{l}920 \\
250\end{array}$ & $\begin{array}{r}1,120 \\
389\end{array}$ & $\begin{array}{r}52,000 \\
600\end{array}$ & $\begin{array}{r}20,000 \\
2,200\end{array}$ & $\begin{array}{r}2,800 \\
540\end{array}$ & $\begin{array}{l}\text { Lower permeable } \\
\text { Upper permeable }\end{array}$ \\
\hline $\begin{array}{l}\text { Manatee } \\
\text { injection } \\
\text { well }\end{array}$ & $\begin{array}{l}2-22-82 \\
2-18-82\end{array}$ & $\begin{array}{l}806 \\
390\end{array}$ & $\begin{array}{r}1,140 \\
700\end{array}$ & $\begin{array}{l}636 \\
632\end{array}$ & $\begin{array}{l}18 \\
18\end{array}$ & $\begin{array}{l}133 \\
162\end{array}$ & Lower permeable \\
\hline
\end{tabular}

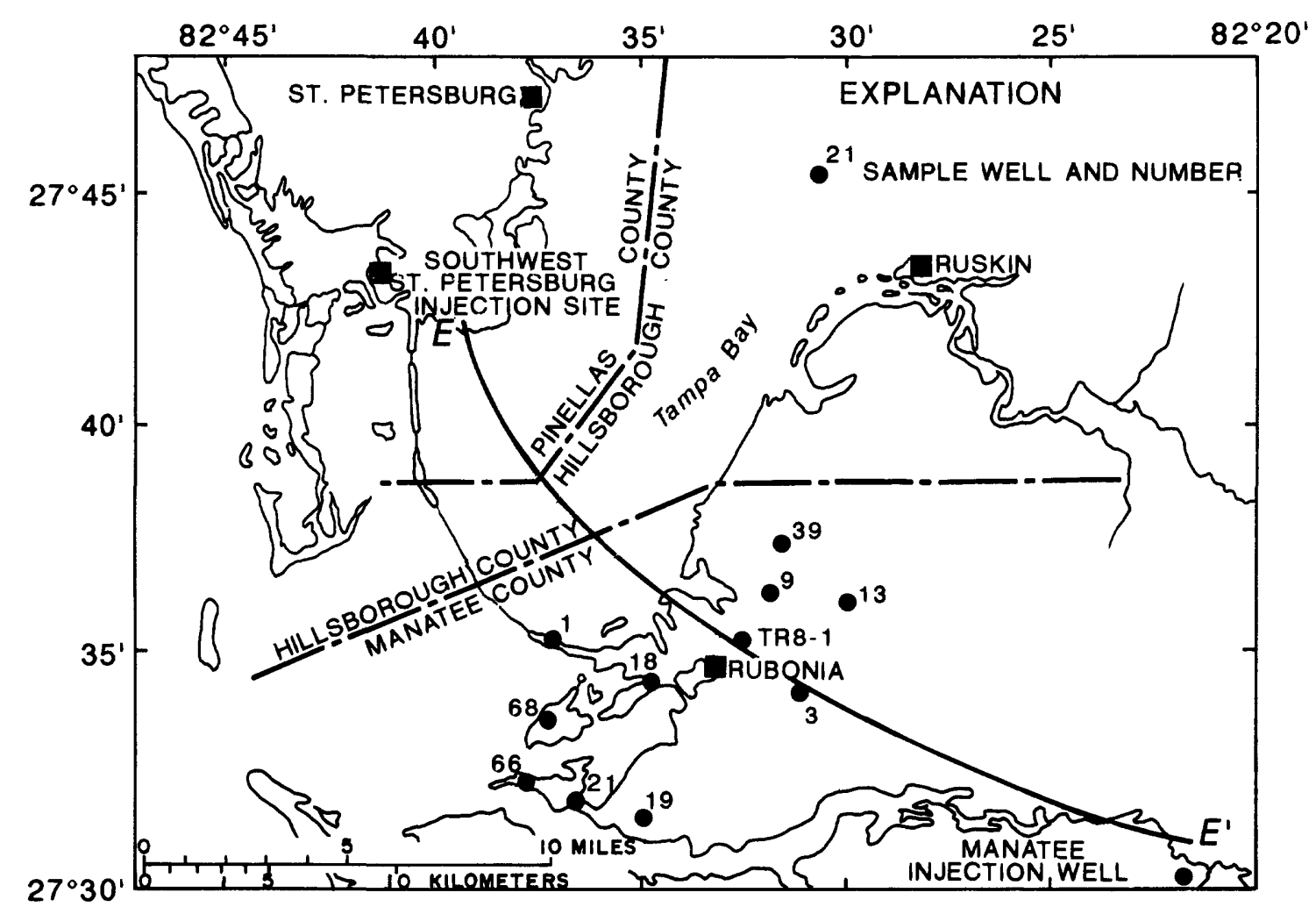

Figure 8.--Chloride concentrations in wells in Manatee and southern Pinellas Counties. 
The origins and distribution of chloride and sulfate concentrations in the Upper Floridan aquifer are described by Steinkampf (1982). The chemistry of water within the aquifers in Florida is a result of the physical and chemical interactions between water and the aquifer medium. Mineral solution and precipitation are among the natural regulators of dissolved solids in the ground water. Dissolution of minerals accounts for increases in the sulfate concentration of ground water as it flows seaward, whereas interaction of seawater with ground water increases the concentration of chlorides in coastal areas.

The chloride-sulfate ratio varies in ground water that flows from central Manatee County to Pinellas County, depending on depth and proximity to Pinellas County (table 3). Both chloride and sulfate concentrations at the Lake Manatee injection well (CH2M Hill, 1982) (fig. 1) are low and result in a chloride-sulfate ratio of about $0.1: 1$ in both the upper and lower permeable zones. At ROMP well TR8-1 near Rubonia, chloride-sulfate ratios reach a maximum of 5.7:1 in the lower part of the lower permeable zone $(1,130 \mathrm{feet}$, equivalent to zone $C$ in Hickey (1982). Chloride concentrations are near seawater values, and sulfate concentrations are greater than that of seawater (Hem, 1985). In the upper and middle permeable zones, the chloride-sulfate ratio is lower than in the lower zone and is about 1.3:1.

Water quality in the lower zone deteriorates between the Manatee injection test well and the southwest St. Petersburg injection site where the chloride-sulfate ratio is $7.1: 1$ (fig. 8) as a result of a greater influence of seawater near the coast. Chloride and sulfate concentrations in zones $C$ and D within the Avon Park Formation exceed those of seawater (Hem, 1975), most likely because of dissolution of evaporite beds within the middle confining unit over long periods of time. Chloride-sulfate ratios for zone $\mathrm{C}$ at the St. Petersburg well most closely resemble average seawater ratios, 7.2:1 (Davis, 1972). Water in the upper permeable zone of the Upper Floridan aquifer remains fairly fresh throughout Manatee County but becomes more saline at the southwest St. Petersburg injection site where a 4.1:1 chloride-sulfate ratio is observed.

\section{Vertical Variation of Specific Conductance}

Trends in dissolved solids can be inferred from the specific conductance of water, which is proportional to the amount of dissolved solids in the fluid. Freshwater has a low dissolved-solids content and, consequently, has a low specific conductance. Samples taken from wells inland at shallow depths typically have specific conductance values less than $300 \mu \mathrm{S} / \mathrm{cm}$, which indicates freshwater. Specific conductance of seawater in the eastern Gulf of Mexico ranges from about 45,000 to $53,000 \mu \mathrm{S} / \mathrm{cm}$ (Goetz and Goodwin, 1980).

Water samples were collected from the bottom of the hole as well TR18- 2 was being deepened from 498 to 820 feet in 1983 and were analyzed for specific conductance and selected water-quality constituents. A fluid specific conductance log was run upon completion of the drilling and stabilization of the water column.

Figure 9 shows that freshwater occurs in the aquifer to 480 feet below land surface where a large increase in specific conductance occurs. The specificconductance log suggests that the transition zone between freshwater and saltwater is between $\mathbf{4 8 0}$ feet and about $550 \mathrm{feet}$; this is confirmed by analysis of a sample pumped from the 2 -inch monitor well. The sample had a specific-conductance value of 26,400 $\mu \mathrm{S} / \mathrm{cm}$, which is midway between the values of freshwater and saltwater. Below 550 feet, specific

Table 3. - Chloride-sulfate ratios within two permeable zones in selected wells in Manatee and Pinellas Counties

\begin{tabular}{lccc}
\hline & $\begin{array}{c}\text { Southwest } \\
\text { St. Petersburg } \\
\text { injection well }\end{array}$ & $\begin{array}{c}\text { Regional } \\
\text { Observation } \\
\text { and Monitor } \\
\text { Well Program } \\
\text { well TR8-1 }\end{array}$ & $\begin{array}{c}\text { Lake Manatee } \\
\text { injection well }\end{array}$ \\
\hline $\begin{array}{l}\text { Upper permeable zone } \\
\text { (Hickey's zone A) } \\
\begin{array}{l}\text { Lower permeable zone } \\
\text { (Hickey's zone C) }\end{array}\end{array}$ & $4.1: 1$ & $1.3: 1$ & $0.1: 1$ \\
\hline
\end{tabular}




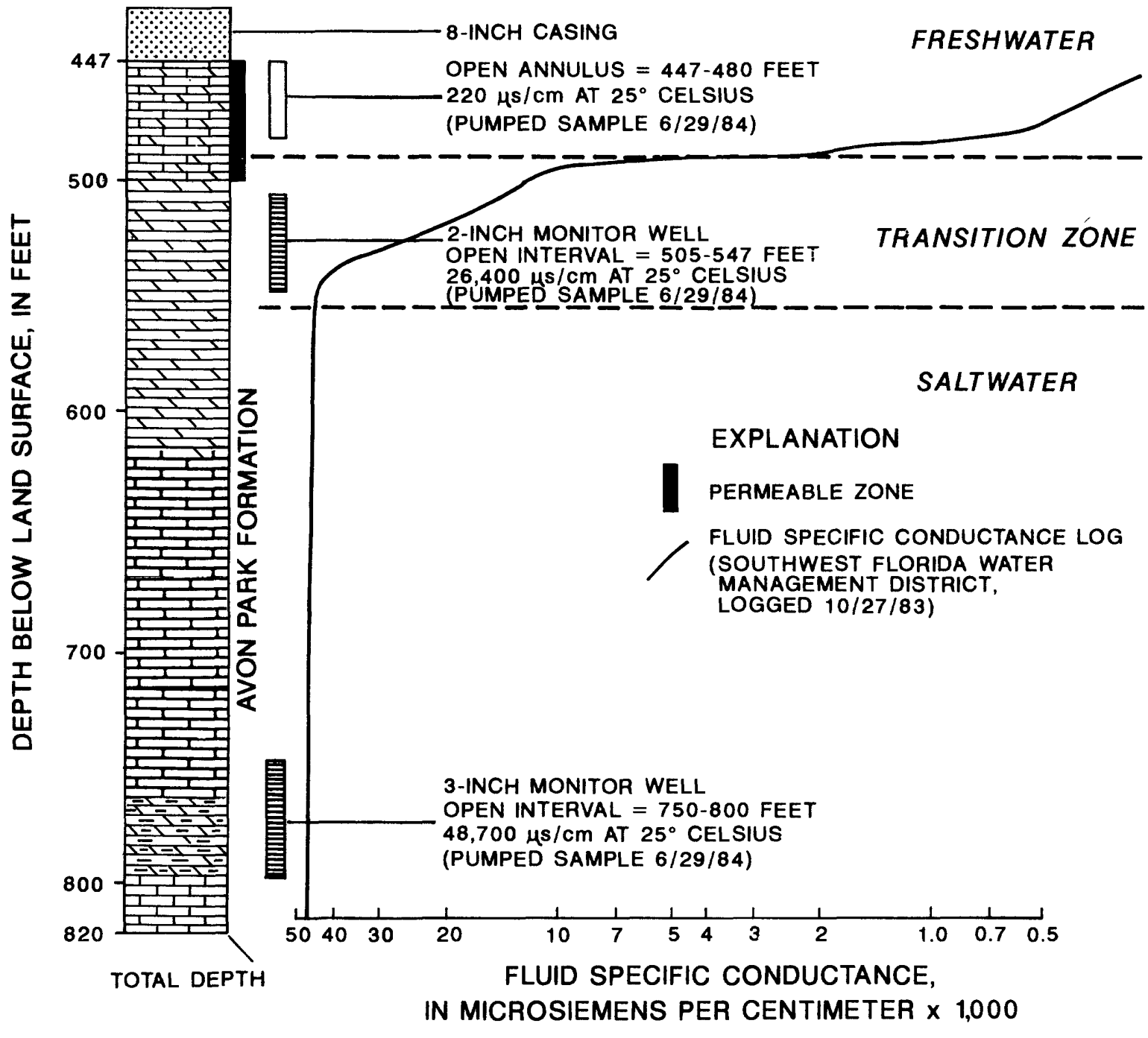

Figure 9. - Permeable zone, monitored intervals, and specific-conductance distribution at site TR18-2, Hernando County. 
conductance of the water increased, as indicated by the specific-conductance $\log$ and the specific conductance of the sample taken from the 3-inch monitor well open to a zone beneath the transition zone.

A similar data-collection program was conducted at the TR8-1 well in Manatee County when the well was deepened in 1984 . Water samples collected from the bottom of the hole during drilling were measured for specific conductance. Results agree well with the specific-conductance $\log$ that was run after the well was allowed to stabilize (fig. 10). The aquifer contains freshwater to about 825 feet, below which specific conductance increases to that of seawater in about 150 feet. The specific conductance log also suggests a change in permeability at about 825 and another change at 950 feet. The changes are indicated as sharp breaks in specific conductance where permeable zones with lower specific conductance contact less permeable zones with higher specific conductance. Highly mineralized water in the deposits from previous seawater inundations or from evaporites is not flushed from the less permeable zones as readily as water in the more permeable zones adjacent to them.

\section{Water-Quality Response to Water-Level Fluctuations}

The potentiometric surface of the Upper Floridan aquifer in the coastal areas of Hernando and Manatee Counties fluctuates as a result of seasonal changes in discharge and recharge, tidal fluctuations in the Gulf of Mexico and Tampa Bay, and man's influence from seasonal pumping and irrigation return on the ground-water system. Fluctuations in atmospheric pressure also can cause minor water-level changes within an aquifer. Changes in water quality may result from the water-level variations.

As previously mentioned, seasonal variation of water levels in Hernando County is minimal, especially in coastal areas (figs. 3 and 4). Reduced pressure in the subsurface during low water-level periods allows for an increased influx of seawater into the aquifer. Water levels show a great seasonal variation in Manatee County, which implies that a large amount of water can enter and exit the groundwater system in coastal areas.

Mean diurnal tidal fluctuations in the Gulf of Mexico at Bayport and lower Tampa Bay (fig. 1) are 3.4 and 2.3 feet, respectively (U.S. Department of Commerce, 1986). Water-level fluctuations associated with tidal changes occur with a greater frequency than seasonal changes and produce oscilla- tions within the ground-water system near the coast. There is a dampening of the magnitude and a delay in the time of occurrence of the tidal fluctuation inland, depending on the distance of the observation well from the gulf or bay and the hydraulic nature of the aquifer and confining units. Magnitude of fluctuation decreases when water levels are measured in lower permeability rock or in deeper zones because of the dampening effect of additional aquifer material. Lag times also increase with a less permeable aquifer medium. The movement of water through the aquifer or across confining units induced by tides carries solutes into and out of the aquifers, thereby increasing the opportunity for mixing to occur between freshwater and saltwater.

In Hernando County, continuous water-quality and water-level data were collected to observe their relation. Hydrographs in figure 11 compare the water levels in wells TR18-1 and TR18-2 and the tidal level in the gulf at Bayport. The wells are 11,000 and 3,700 feet, respectively, from the gulf. Water levels in well TR18-2 show a lag time of about 90 minutes and a magnitude dampening of about 89 percent. The water level in well TR18-1 shows a greater lag time of 268 minutes and a dampening effect of 96 percent as a result of the greater distance between the shoreline and the well.

A temperature and specific-conductance monitor was installed in well TR18-2 on March 29, 1984, to record specific conductance simultaneously with water level in the well, which is open to the transition zone. The sensing probe was placed in the uncased interval between 505 and 547 feet (fig. 9). Water levels in well TR18-1, specific-conductance data for well TR18-2, and tidal fluctuations at Bayport are shown in figure 12 .

As the tidal waters receded on March 29, following an unusually high tide of nearly 5 feet, a fairly stable diurnal tidal pattern was reestablished and was reflected in the water levels in the well. Associated with the high tide was a specific conductance of at least greater than $29,000 \mu \mathrm{S} / \mathrm{cm}$, which was observed when the minimonitor was installed. Following the unusual tide, specific conductance established a fairly uniform pattern that was coincident with, but lagging behind, the tidal pattern. Average amplitude of the specific-conductance fluctuation for the period March 30 through April 3, 1984, was about $1,250 \mu \mathrm{S} / \mathrm{cm}$. The average specific-conductance fluctuation for well TR18-2 was about $3,500 \mu \mathrm{S} / \mathrm{cm}$. The value probably would have been higher had the monitor been installed prior to the unusually high tidal peak. 


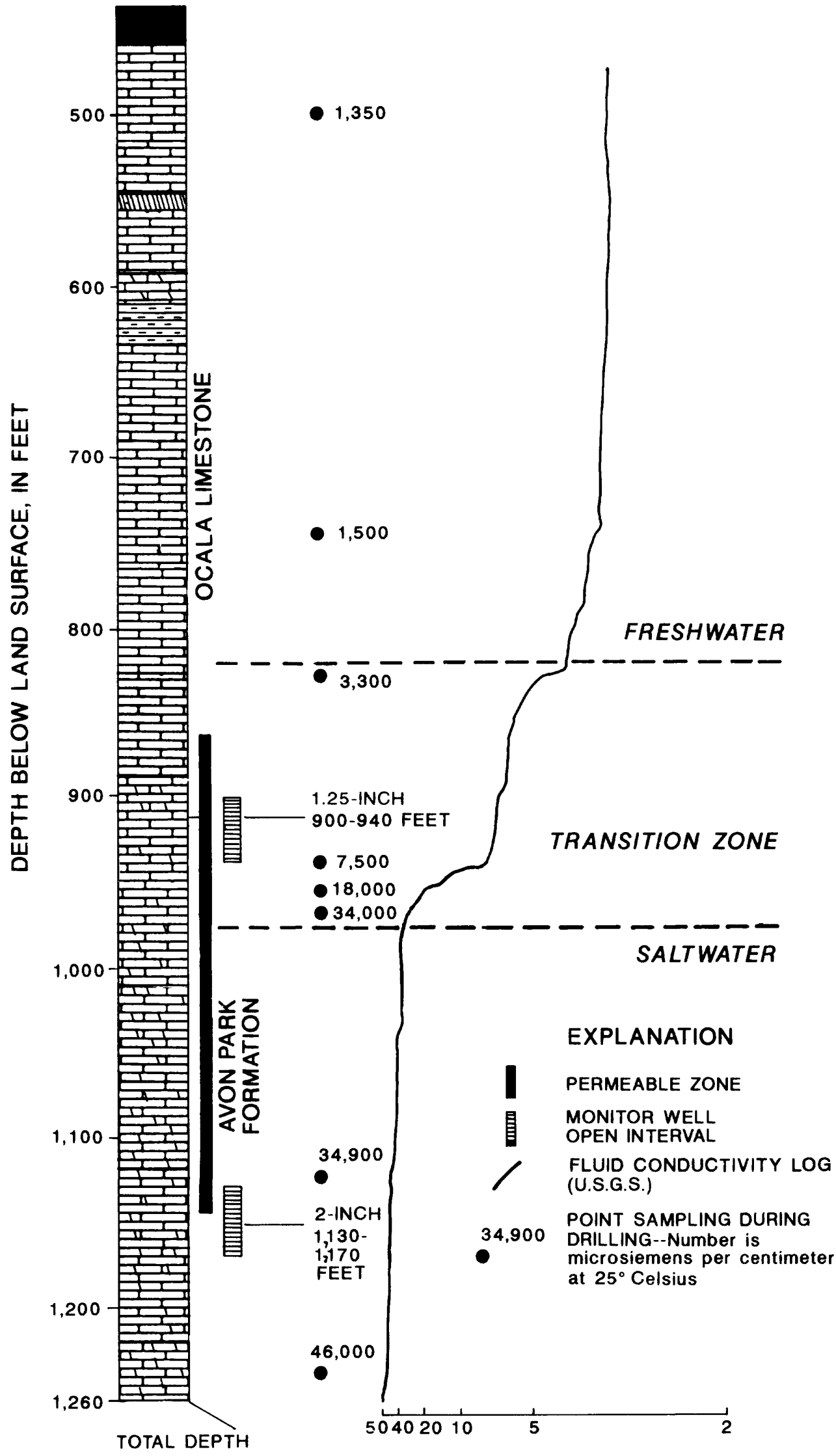

FLUID SPECIFIC CONDUCTANCE, IN MICROSIEMENS PER CENTIMETER X 1,000

Figure 10. - Permeable zone, monitored intervals, and specific-conductance distribution at site TR8-1, Manatee County. 


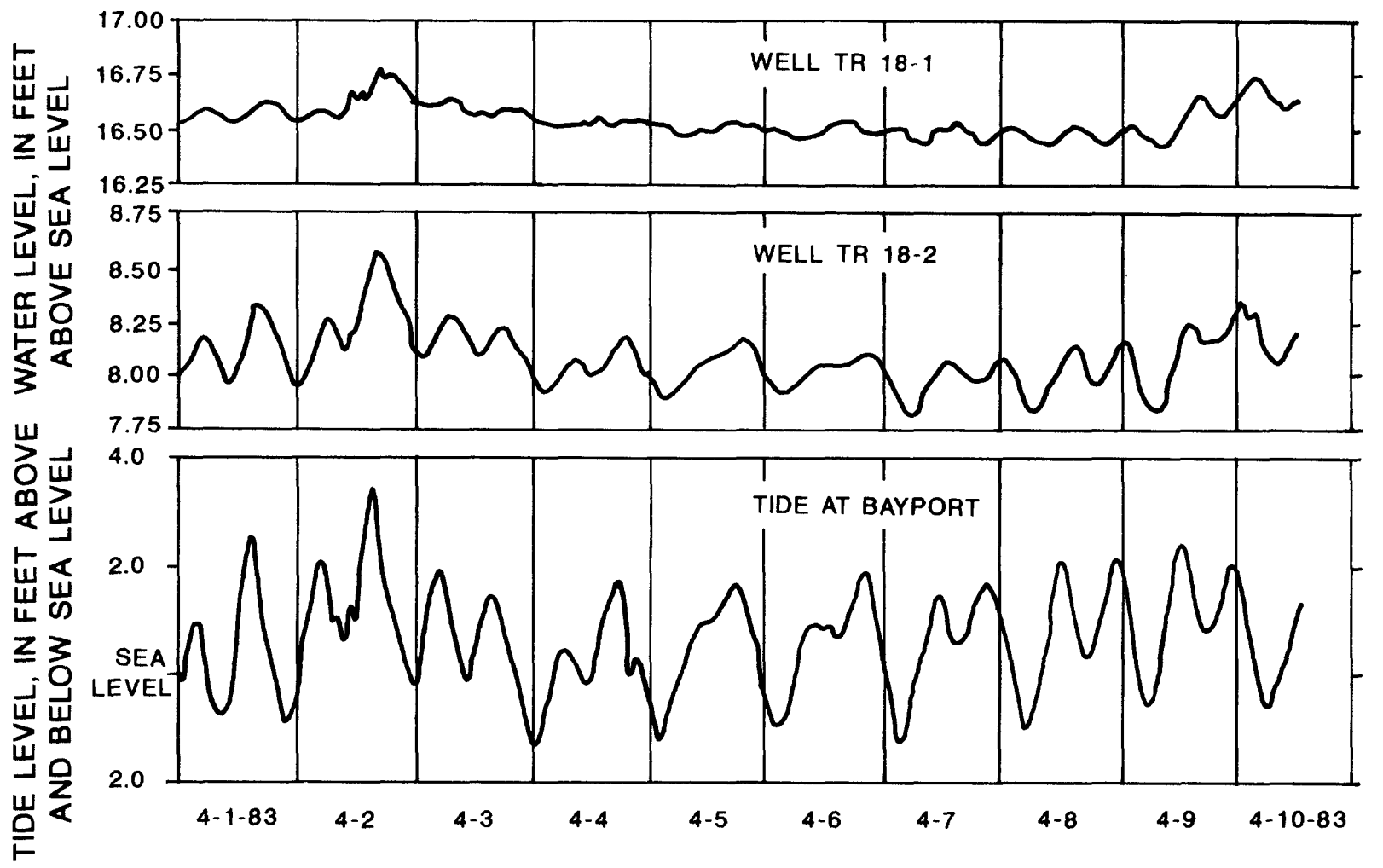

Figure 11.--Water levels in wells TR18-1 and TR18-2 and tidal fluctuations at Bayport, April 1-10, 1983. 


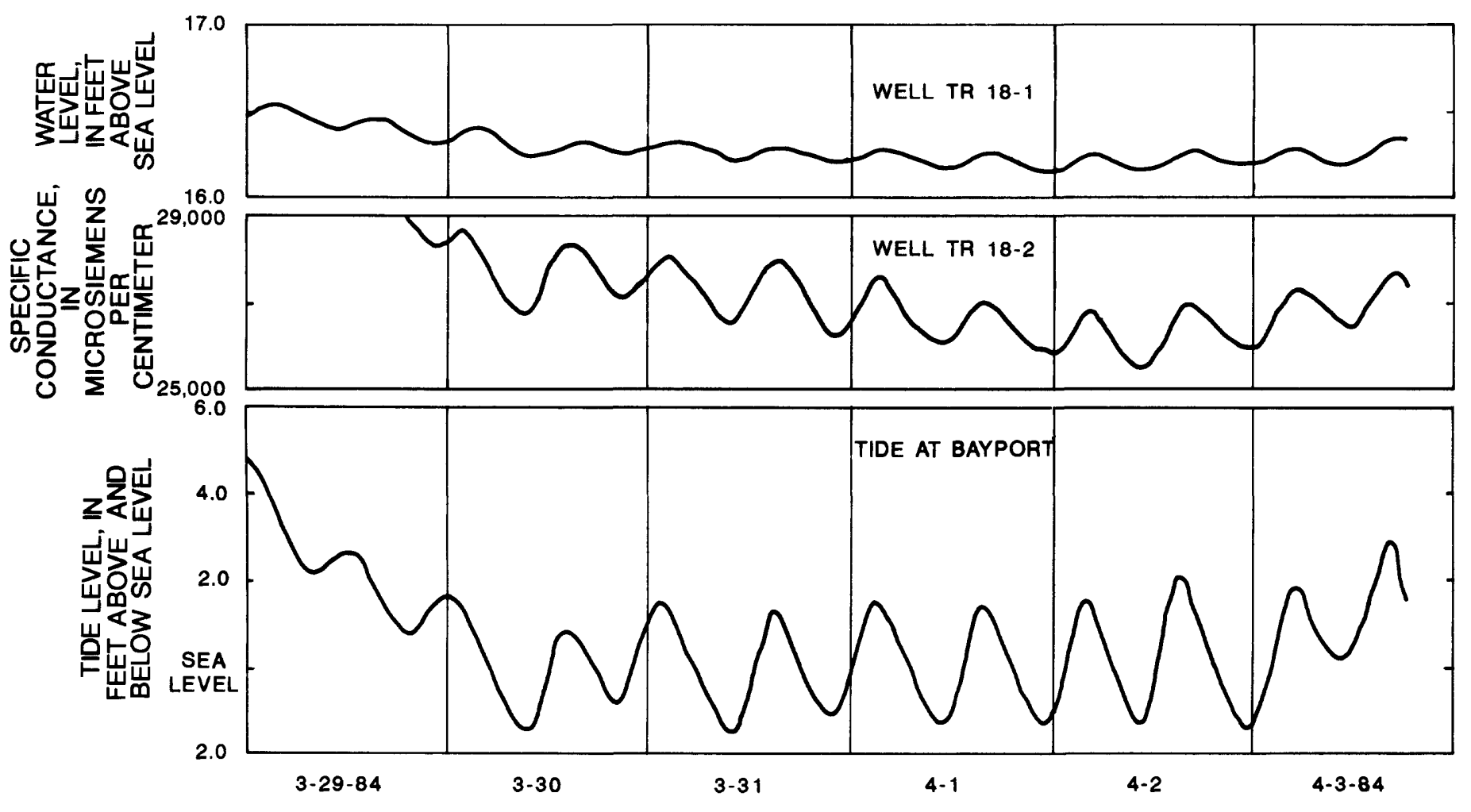

Figure 12. - Relation between specific conductance in water from well TR18-2, water levels in well TR18-1, and tidal fluctuations at Bayport, March 29 through April 3, 1984. 

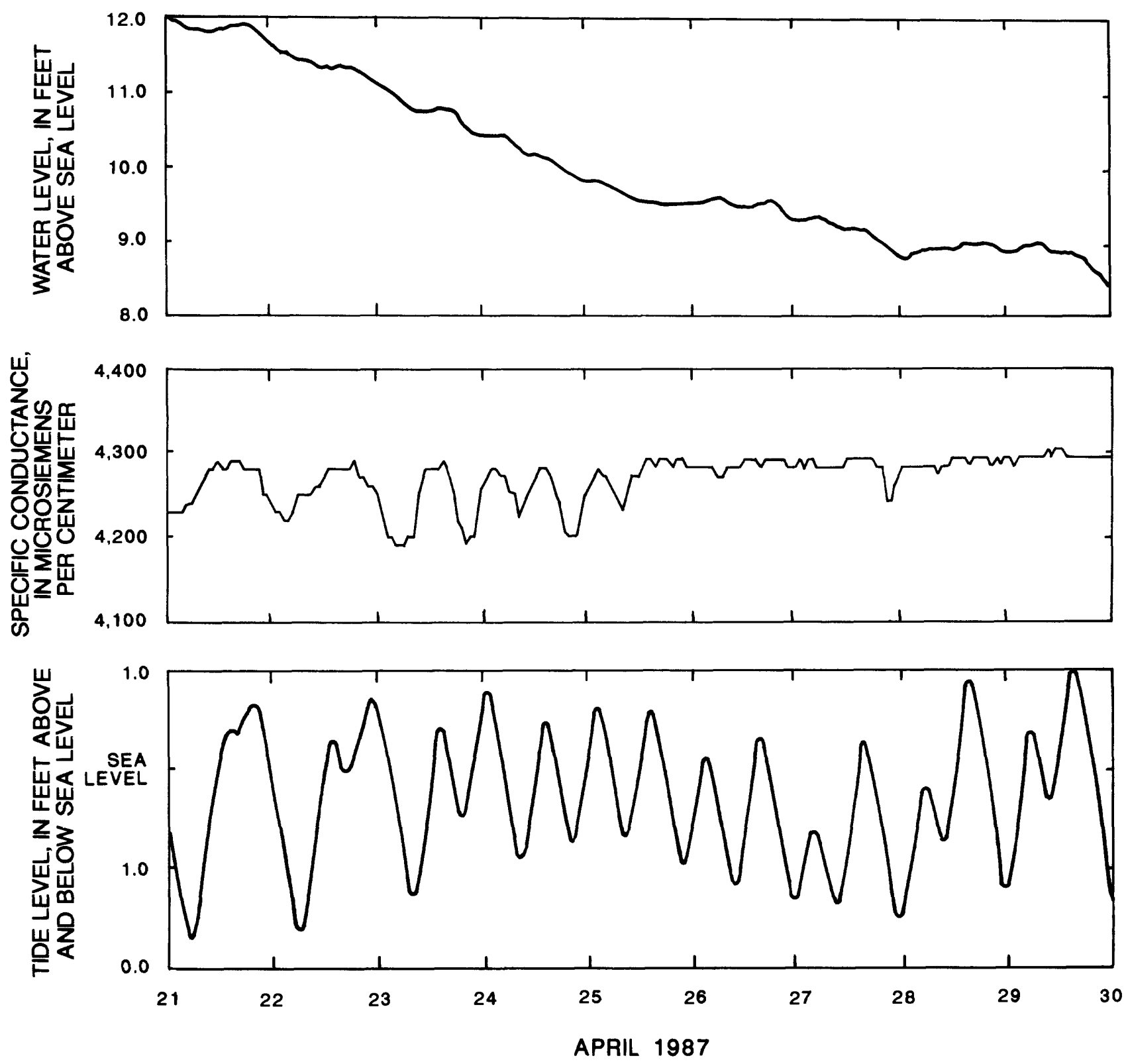

Figure 13.--Water levels and specific conductance in well TR8-1 and tidal fluctuations in Tampa Bay. 
In Manatee County, at well TR8-1, continuous water-quality and water-level data were collected from the open interval between 900 and 940 feet to record specific-conductance changes within the transition zone. Specific-conductance and waterlevel data from well TR8-1 and tidal data from Tampa Bay near Ruskin are illustrated in figure 13. Periodic fluctuations of the specific-conductance values with respect to time suggest that there is a tidal influence on the water quality in the well (fig. 13). Unfortunately, a more precise relation between water quality and water levels could not be made because of well-construction problems.

Tides in Tampa Bay are generally semidiurnal but are diurnal a few days each lunar month. Tidal fluctuations at Ruskin (fig. 1) for the period of record shown have a maximum amplitude of 2.5 feet. Waterlevel fluctuation in well TR8-1 due to tides is about 0.25 foot, indicating a dampening effect of the subsurface medium of about 90 percent.

Compared to the Hernando County site, the concept of tides affecting water levels in the subsurface at the Manatee County site is more complicated. Tidal pressures that influence the subsurface have two sources to consider: (1) at the submarine outcrop where there is a direct exchange of water with tidal changes, and (2) beneath Tampa Bay where the tidal response is due to loading changes and the compressibility of the aquifer.

\section{Interface Theory and Cyclic Seawater Flow In the Zone of Transition}

In the transition zone between freshwater and saltwater, two important processes are occurring. One is advection, the process by which nonreactive solutes are transported by flowing ground water at a rate equal to the average linear velocity of the water (Freeze and Cherry, 1979, p. 389). The other process is hydrodynamic dispersion that causes dilution and spreading of the solute because of physical mixing (mechanical dispersion) during fluid advection and because of molecular diffusion. Mechanical dispersion is caused by (1) velocity differences among water molecules in individual pore channels; (2) differences in pore sizes along the flow paths of water molecules; and (3) the tortuosity, branching, and interfingering of pore channels (Freeze and Cherry, 1979, p. 75).

Cooper and others (1964) stated that the reciprocative motion of the saltwater front that results from tidal fluctuations or from water-level fluctuations caused by variations in recharge or pumpage could provide a powerful enough mechanism to create a zone of diffusion. He also postulated that, wherever there is a zone of diffusion in a coastal aquifer, the seawater is not static but flows in a perpetual cycle from the sea floor, into the zone of diffusion, and back to the sea floor. Cooper and others (1964) also stated that head losses in the saltwater environment may be caused by this cyclic flow of saltwater. Field evidence supported by solutetransport modeling indicates that variable density fluid is indeed in motion.

Hubbert (1969, p. 102-104) gives the following expression for determining the altitudes of a point on an interface that separates two nonhomogeneous fluids:

$$
\begin{gathered}
\mathrm{z}=\text { elevation of point on interface (feet); } \\
\mathrm{g}=\begin{array}{r}
\text { acceleration due to gravity (feet per } \\
\text { second squared); }
\end{array} \\
\mathrm{p}=\begin{array}{c}
\text { density of the liquid (grams per cubic } \\
\text { centimeter); and }
\end{array} \\
\emptyset=\text { gh }=\text { potential at a point in a liquid flow } \\
\text { system with head, } \mathrm{h}(\mathrm{feet}), \text { measured } \\
\text { relative to standard datum. }
\end{gathered}
$$

The interface represents a configuration of dynamic equilibrium, which means that it will adjust itself to a new position of equilibrium for each change in the state of flow of either of the fluids. Substituting the expression for $\emptyset$ into equation 1 and reducing the equation yields:

$$
z=\left[\left(\frac{p_{2}}{p_{2}-p_{1}}\right)\left(h_{2}\right)-\left(\frac{p_{1}}{p_{2}-p_{1}}\right)\left(h_{1}\right)\right]
$$

Head and density data were collected at well TR18-2 and substituted into equation 2:

$$
\begin{aligned}
z & =\left[\left(\frac{1.0210 \mathrm{~g} / \mathrm{mL}}{1.0210 \mathrm{~g} / \mathrm{mL}-1.0101 \mathrm{~g} / \mathrm{mL}}\right)(-3.40)\right. \\
& \left.-\left(\frac{1.0101 \mathrm{~g} / \mathrm{mL}}{1.0210 \mathrm{~g} / \mathrm{mL}-1.0101 \mathrm{~g} / \mathrm{mL}}\right)(2.54)\right]
\end{aligned}
$$

$$
z=-554 \text { feet }
$$

where subscript 1 data are from the well open to the transition zone, subscript 2 data are from the well open to the saltwater zone, and datum is sea level. The calculated interface depth of 561 feet below land 
surface is within a few feet of where the saltwater zone is estimated to begin based on chemical and geophysical log data (fig. 9, 550 feet). Head and density data collected from the 1-inch freshwater well and substituted into equation 2 , in lieu of the 2-inch transition-zone well data, yield virtually the same result. If the well known Ghyben-Herzberg principle, which determines the altitude of the saltwater zone under static conditions, had been applied, saltwater would have been determined to be about 200 feet higher.

Data collected at well TR8-1 was also applied to Hubbert's (1969) equation:

$$
\begin{aligned}
\mathrm{z} & =\left[\left(\frac{1.0250 \mathrm{~g} / \mathrm{mL}}{1.0250 \mathrm{~g} / \mathrm{mL}-1.0008 \mathrm{~g} / \mathrm{mL}}\right)(-4.85)\right. \\
& -\left(\frac{1.0008 \mathrm{~g} / \mathrm{mL}}{1.0250 \mathrm{~g} / \mathrm{mL}-1.0008 \mathrm{~g} / \mathrm{mL}}\right)(16.67) \\
z & =-895 \mathrm{feet}
\end{aligned}
$$

Land-surface altitude is about 15 feet, and the calculated interface depth is 910 feet below land surface, which is very near the depth estimated from geophysical and water-quality data (980 feet, fig. 10). Although calculations based on the field data and the above equation support the concept of cyclic saltwater flow, convective circulation is not the only mechanism contributing to saltwater flow and creative values of saltwater heads in coastal Manatee County. Saltwater heads also may be depressed below sea level because of pumpage of saltwater at phosphate mines north of the study area.

\section{SIMULATION OF THE GROUND-WATER SYSTEM WITH NUMERICAL MODELS}

Modeling a ground-water system involves a multistep process. A conceptual model is first developed that represents a transition between the physical system and numerical model representation. The conceptual model generalizes the hydraulic and physical characteristics that are known about the ground-water system. The generalized parameters are then transferred to an existing ground-water flow model data base to simulate constant-density flow. The assumptions and values of the parameters used to describe the subsurface are adjusted within reasonable limits until the simulated results generally match observed values. After the flow model has been developed, the density dependent, solutetransport model can be developed using the previously tested and confirmed hydrogeologic parameters.
Ground-water flow and solute-transport models were developed for the Hernando and Manatee County areas to aid in understanding how saltwater intrusion relates to the hydraulics and hydrogeology in the subsurface. A ground-water flow model for simulating constant-density flow for the Hernando County area was developed and is described in the following section. A model code separate from the subsequent solute-transport model was used to test and confirm hydraulic values that were then applied to the solute-transport model. Ground-water flow in the Manatee County area was simulated using only a solute-transport model in a constant-density mode, and fluid density and concentration were equivalent to freshwater.

In development of any model, certain assumptions are made about the system, and certain circumstances place limitations on the model. The general assumptions and limitations for both study areas are listed below:

1. Flow is parallel to the section line of the twodimensional model.

2. The base of the Upper Floridan aquifer is impermeable and is a no-flow boundary.

3. Flow is through a porous media.

4. Hydraulic properties within a node or an element are uniform.

5. The rate of freshwater inflow is constant during a timestep.

6. Boundaries are placed at a sufficient distance such that conditions at the boundary do not change with time.

7. The seawater boundary in the solute-transport simulations is hydrostatic.

\section{Hernando County}

The Hernando County modeled area extends laterally from Indian Bay inland about 8,000 feet to a point that approximately separates the aquifer discharge area from the aquifer recharge area (fig. 1, A-A'). The modeled area extends vertically from sea level to a depth of 735 feet (fig. 14).

\section{Ground-Water Flow Model}

Prior to applying the solute-transport model, the U.S. Geological Survey ground-water flow model described by Trescott (1975) and Trescott and Larson (1976) was used to aid in estimating input parameters to the transport model and in quantifying steady-state fluxes entering and leaving section A-A' (fig. 1). The 


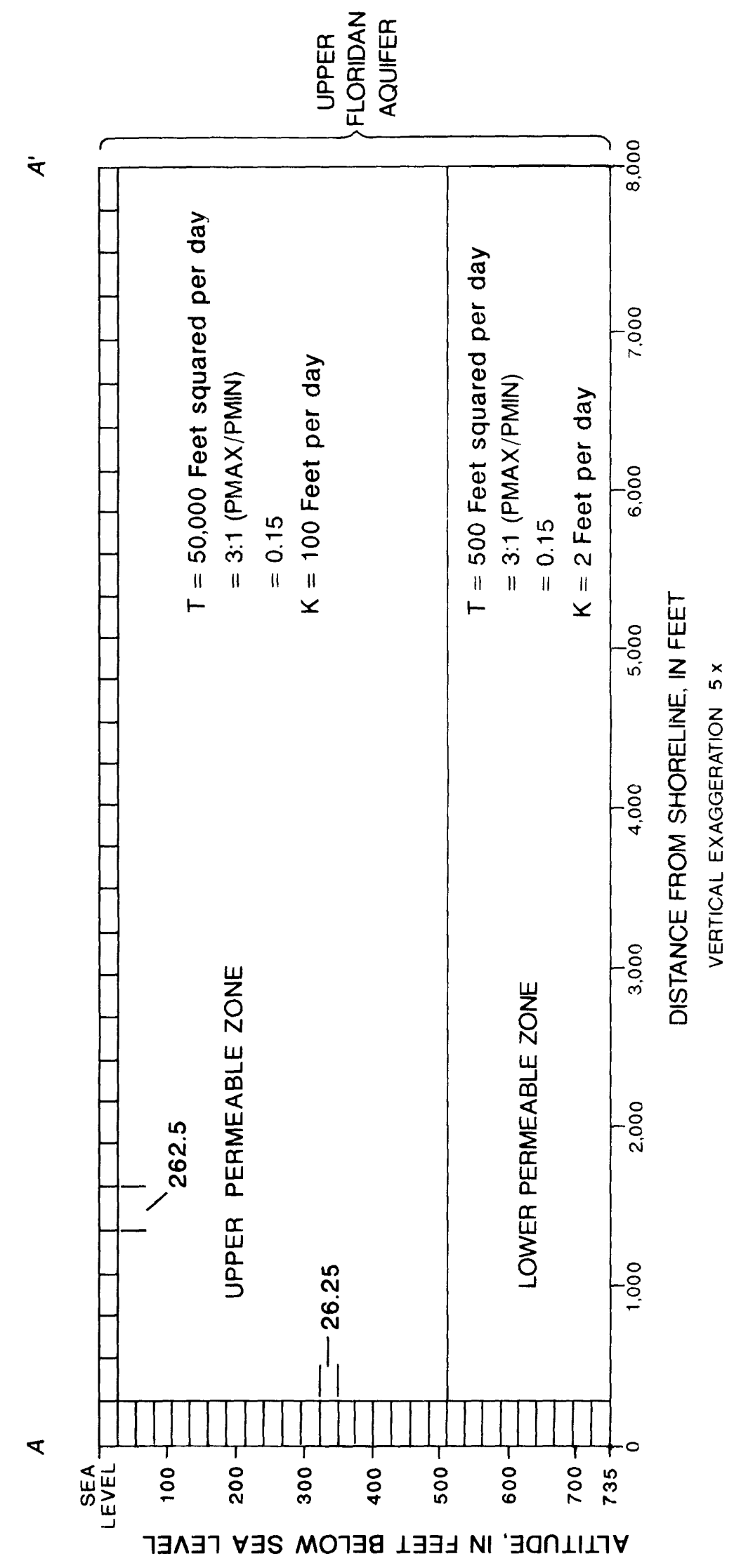

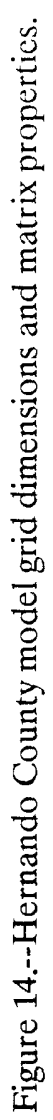


flow model was developed within a conceptual framework and calibrated as follows:

1. A sharp interface location was estimated from the data in figure 5. The interface is defined as a no-flow boundary. (Saltwater was assumed to be static, and the transmissivity on the saltwater side of the interface was set equal to zero.)

2. A constant-head boundary of $\mathbf{1 2}$ feet (Barr and Schiner, 1982a; 1982b) was imposed at the inland boundary and was assumed uniform with depth.

3. A transmissivity of $50,000 \mathrm{ft}^{2} / \mathrm{d}$ was used for the upper 500 feet of aquifer, and the lower 235 feet of aquifer was estimated to have a transmissivity of $500 \mathrm{ft}^{2} / \mathrm{d}$ based on the previously discussed aquifer testing. Anisotropy (lateral to vertical ratio of hydraulic conductivity) was estimated to be 3:1.

4. Upward leakage was simulated with imaginary pumping wells in the upper layer of grid blocks. Leakage rates were adjusted by trial and error until heads were simulated to within a few tenths of a foot of observed values (Barr and Schiner, 1982a; 1982b).

5. A head-dependent sink function (Ryder, 1982, p. 32), where land surface behaves as constant-head boundary, was then substituted for the imaginary line of wells.

6. Upward leakage rates were divided by grid-block area so that the flux per unit area could be adapted to the solute-transport model.

\section{Solute-Transport Model}

Solute transport was simulated using the U.S. Geological Survey saturated-unsaturated transport (SUTRA) model described by Voss (1984). The SUTRA model is a complex computer program that employs a two-dimensional, hybrid finite-element and integrated finite-difference method to approximate the equations that describe the two interdependent processes that apply in the study areas: (1) fluid density-dependent saturated ground-water flow and (2) transport of a solute in the ground water. Voss (1984) provides complete documentation of the SUTRA model, including physical-mathematical fundamentals and numerical methodology.

The SUTRA finite-element model (Voss, 1984) was developed in cross-section along A- $\mathrm{A}^{\prime}$ (fig. 1) to include 899 nodes and 840 elements. Element size is uniform, each with dimensions of 262.5 feet and 26.25 feet horizontally and vertically, respectively. Thickness of the grid is 3.281 feet.

Boundary conditions for the Hernando County SUTRA model simulations include a hydrostatic pressure boundary at the shoreline. The position of the boundary implies that no movement occurs in its vicinity; however, data suggest that ground-water flow is occurring inland near well TR18-2. It is assumed that the western boundary is positioned sufficiently far from the mixing zone so that model results are acceptable. If data become available that indicate there is movement in the vicinity of the boundary, placement of the boundary farther seaward from the shoreline would be warranted. The boundary condition at the top and landward edge of the model is specified flux. The solute-transport model simulates leakage out of the aquifer along the top with rates determined from the flow model, as previously described. Along the landward edge, for the nodes at $A^{\prime}$ (fig. 1), the total influx approximates the total rate of upward leakage across the upper surface. The base of the aquifer at 735 feet below sea level is simulated as a no-flow boundary.

Other SUTRA model input parameters, as defined by Voss (1984), are as follows:

Anisotropy: $=\frac{\text { PMAX }}{\text { PMIN }}=3: 1$ [dimensionless],

Porosity: POR $=0.15$ [dimensionless],

Base fluid density: RHOW $\varnothing=1,000 \mathrm{~kg} / \mathrm{m}^{3}$,

Fluid coefficient of density change with concentration: $\mathrm{DRWDU}=700 \mathrm{~kg} / \mathrm{kg} \cdot \mathrm{m}^{3}$,

Base fluid solute concentration: URHOW $\varnothing-0.00$ [dimensionless],

Solute concentration of saltwater entering the aquifer: $\mathrm{UBC}=0.0318$ [dimensionless],

Fluid viscosity: VISC $\varnothing=1 \times 10^{-3} \mathrm{~kg} / \mathrm{m} \cdot \mathrm{s}$,

Gravitational acceleration: GRAVY $=-32.2 \mathrm{ft} / \mathrm{s}^{2}$,

Upstream weighting factor: UP $=0.00$ [dimensionless],

Specified pressure boundary condition factor: $\mathrm{GNU}=0.033 \mathrm{ft} \cdot \mathrm{s}$,

Longitudinal dispersivity: ALMAX $=65.6$ feet,

Transverse dispersivity: ATAVG $=13.1$ feet.

Anisotropy (ratio between lateral and vertical hydraulic conductivity) was estimated to be 3:1 (Ryder and Mahon, 1989). Porosity values were obtained from borehole geophysics estimates of bulk porosity for the permeable zones. The value of fluid coefficient of density change with concentration provides a numerically stable solution of saltwater density based on a freshwater density of $1,000 \mathrm{~kg} / \mathrm{m}^{3}$ and a seawater salinity of $35.7 \mathrm{mg} / \mathrm{L}$ (from Voss, 1984, p. 198). The value of fluid viscosity was taken from Weast (1972) for freshwater. Upstream weighting 
factor and specified pressure-boundary factor are suggested by Voss (1984). Dispersivity values are dependent on and were calculated by a relation between dispersivity and element length to produce a stable, nonoscillating solution of the concentration field (Huyakorn and Pinder, 1983).

Pressures and concentrations within the matrix were set equal to zero to begin the simulation. The initial timestep length was set equal to 122 days, and the model was run until the pressure and concentration distribution came to equilibrium. With the exception of slight oscillations of computed solute concentrations (in time and space), equilibrium conditions were achieved after about 1,500 years. To eliminate the oscillations, the timestep length was reduced to 14 days and the model was rerun until changes in the concentration distribution over time and space were negligible. Results of the steady-state model simulation are shown in figure 15.

Chloride data (as percent seawater measured and simulated) are shown superimposed on the pore-velocity field computed by the model. The concentration distribution was calibrated against data from observation wells until they closely matched. Flow velocities computed at the centroid of each element show the saltwater moving inland from the coast, mixing with freshwater in the area of the interface, and moving back toward the sea floor, simulating a zone of diffusion similar to that postulated by Cooper and others (1964). The highest velocity simulated, $3.6 \mathrm{ft} / \mathrm{d}$, occurs in the uppermost row of elements near the seaward side of the model. Velocities are lowest in the deeper, low-permeability zone, averaging less than $0.01 \mathrm{ft} / \mathrm{d}$. There is a distinct break in the velocities and in the salinity contours at the 500-foot altitude, which is the contact between zones of differing transmissivity.

Because a calibration is not a unique solution for the ground-water system, there is a degree of uncertainty in any simulation of a hydrogeologic system. Therefore, it is desirable to test the sensitivity of the model to changes in input parameters. The following parameters were changed uniformly over the modeled area based on reasonable ranges of values as follows:

\begin{tabular}{|c|c|}
\hline Longitudinal dispersivity ....... & \pm 25 percent \\
\hline Transverse dispersivity & \pm 50 percent \\
\hline Hydraulic conductivity & +100 \\
\hline 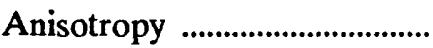 & 1:1 \\
\hline
\end{tabular}

A steady-state solution was computed for each changed parameter while other parameters remained unchanged from their original values. The results of most of these computations are shown in figures $\mathbf{1 6}$ and 17.

The change in position of the 5- and 50-percent seawater-salinity contours was chosen to show model sensitivity to the changed parameters. Five-percent saltwater salinity is equivalent to a chloride concentration of about $900 \mathrm{mg} / \mathrm{L}$. Contours for the \pm 25 percent change in longitudinal dispersivity (not shown in figs. 16 and 17) plotted almost directly on the calibration contour, thus indicating that the model was not very sensitive to this range of changes in longitudinal dispersivity. The contour shifted landward a few hundred feet when the dispersivity was reduced and seaward when it was increased. The change from anisotropic to isotropic conditions made little difference in the position of the contour. Doubling the hydraulic conductivity caused the 5-percent contour to shift landward a maximum distance of 1,700 feet and the 50-percent contour to shift landward a maximum distance of 1,300 feet. Decreasing the influx of freshwater caused the interface to move inland, with greatest changes occurring near the low-concentration areas. For nearly all sensitivity simulations, the maximum differences in the positions of the contour occurred at about 500 feet below sea level where the contact between zones of differing transmissivity occurs.

Because the flux rates used in the model simulations were derived from flow-model simulations, it is also necessary to test the sensitivity of the model to changes in flux rates. These results can be interpreted from figure 18, which shows movement of the line of equal salinity as a result of reducing the steady-state influx based on hypothetical groundwater withdrawals as described later. A steady- state solution also was computed for each reduction of influx while other input-parameter values remained unchanged.

A regional ground-water flow model developed by Ryder (1982) was used to simulate effects of a hypothetical ground-water withdrawal at a total rate of $60 \mathrm{Mgal} / \mathrm{d}$ from two points eastward of U.S. Highway 19. The hypothetical location and distribution of pumpage (fig. 19) were chosen because they result in a parallel orientation of the new equipotential lines to the coast near section A-A'. Since the cross-sectional model is oriented perpendicular to the coast and the equipotential lines, it is necessary to preserve the orientation of the simulated equipotential lines so that flow will be parallel to the cross section, therefore not violating one of the limitations of the model. Figure 19 shows that the hypothetical pumpage simulated by the regional 


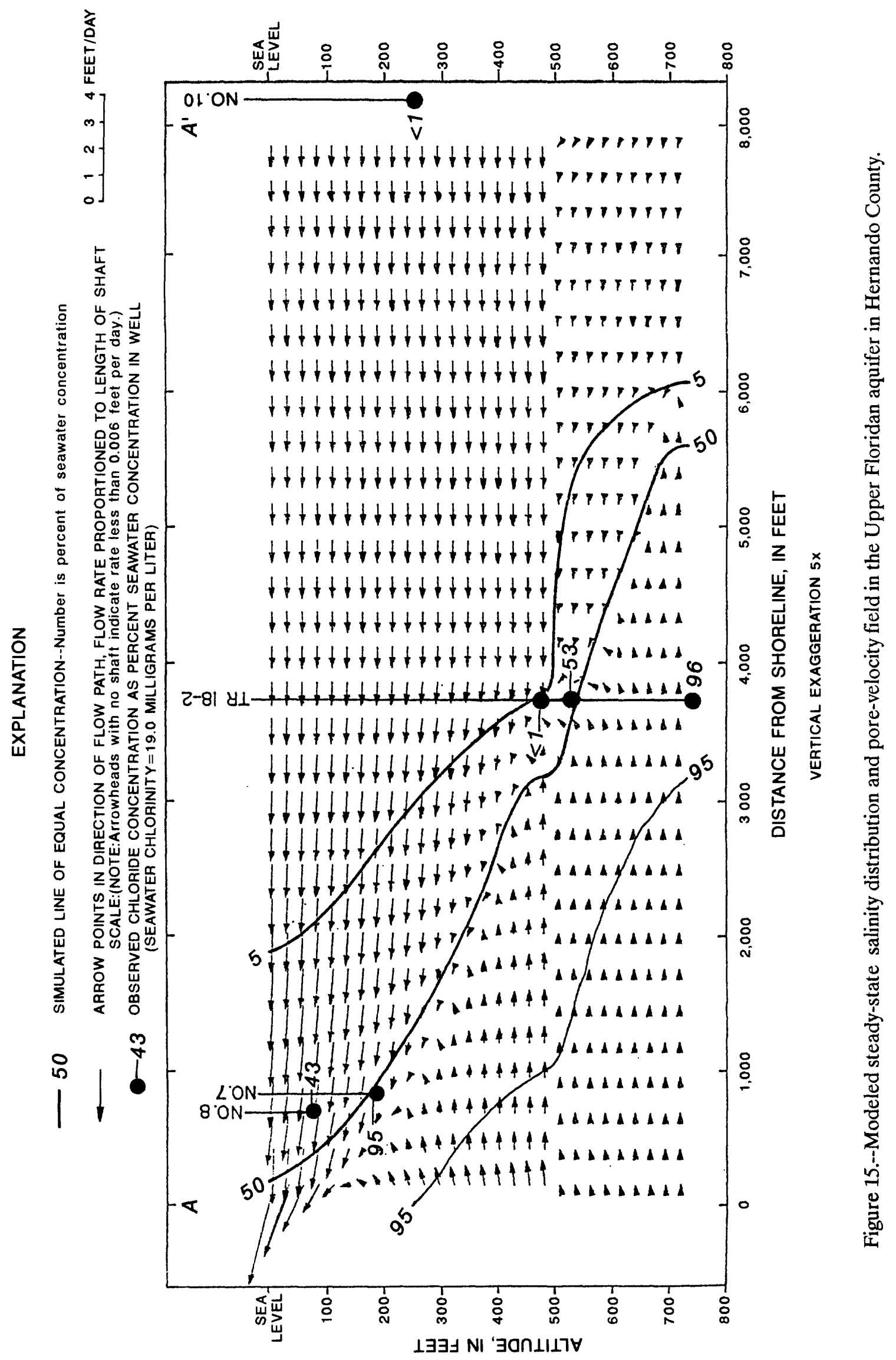




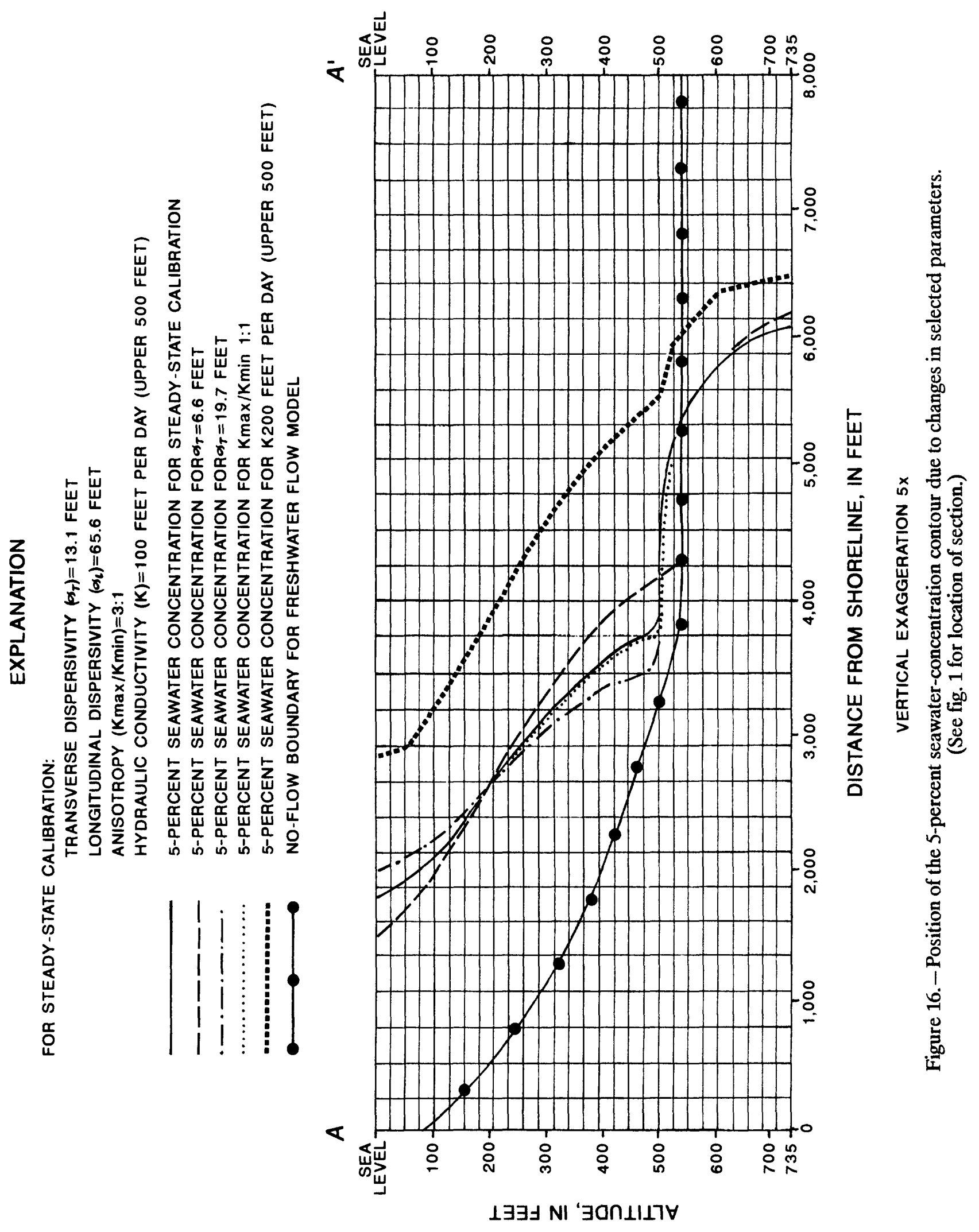




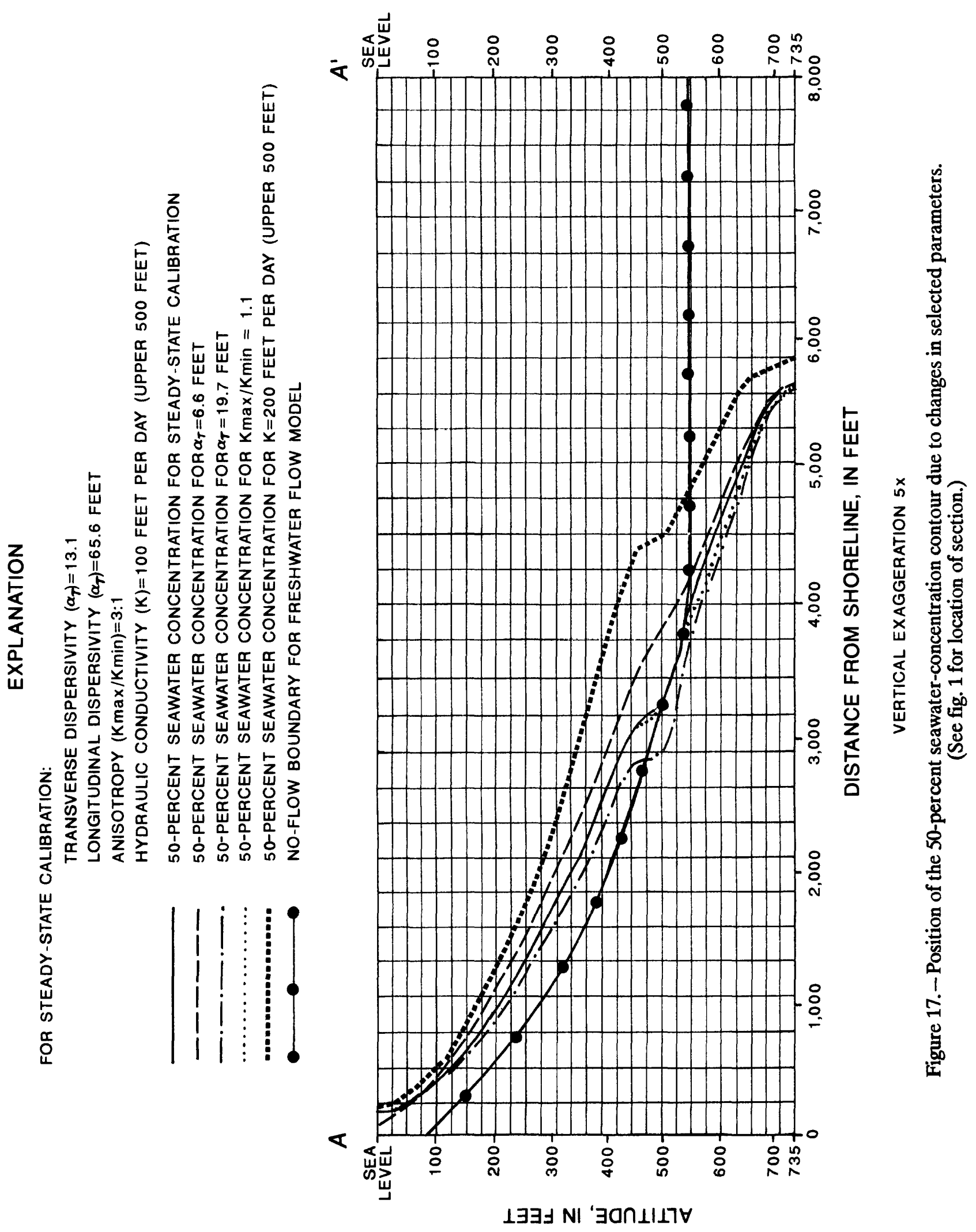




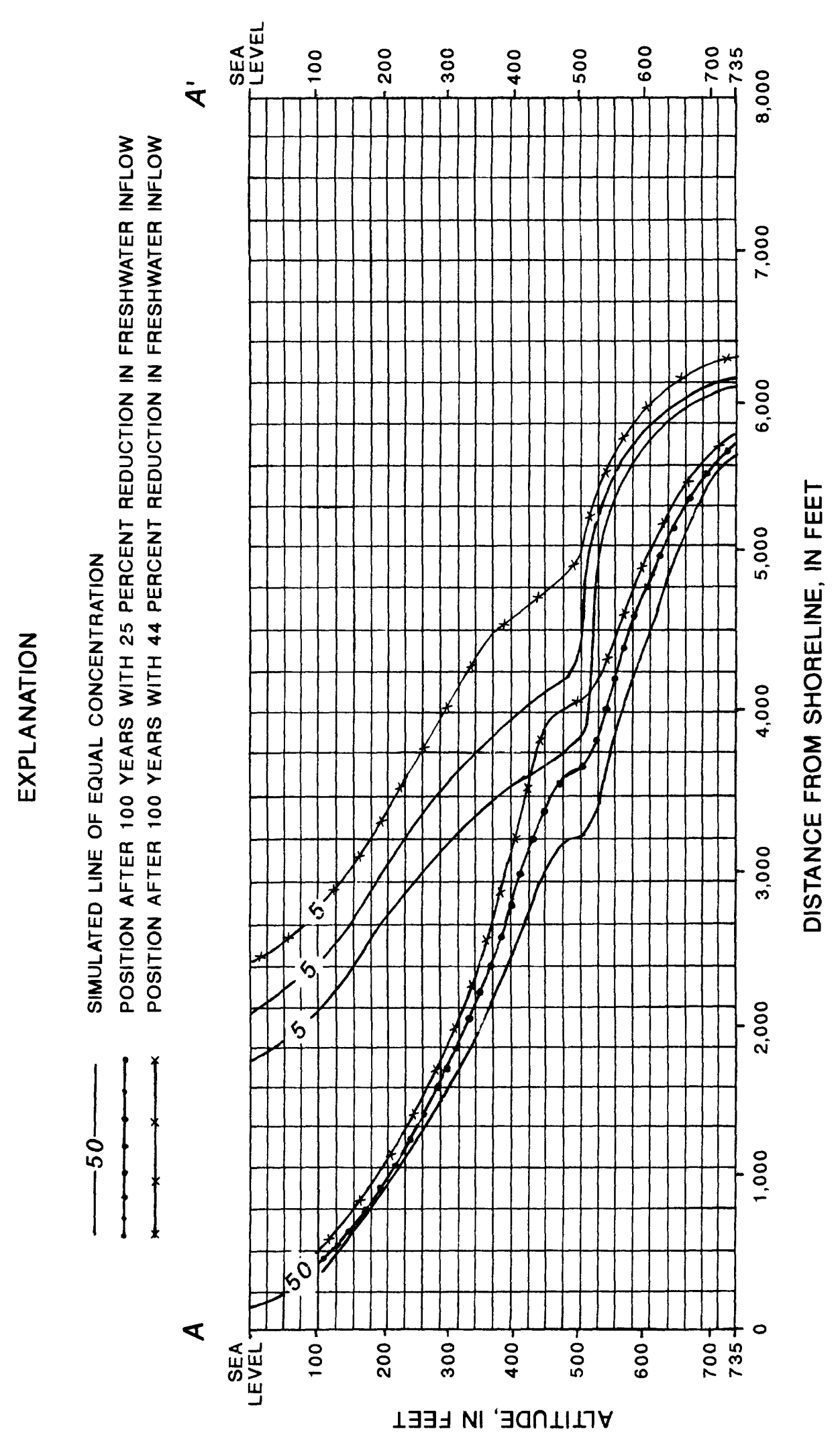

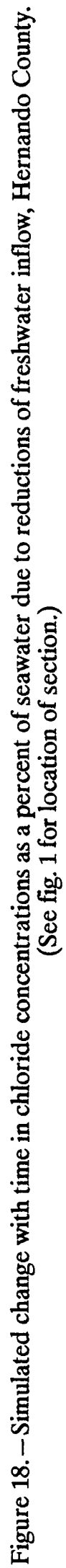


model caused about 2 feet of head decline at $A^{\prime}$. The new head of about 10 feet at $A^{\prime}$ was used to define a new constant-head boundary in the cross-sectional flow model to simulate changes resulting from pumpage of $60 \mathrm{Mgal} / \mathrm{d}$.

While applying the new head conditions to the cross-sectional flow model, upward leakage rates were allowed to adjust by using a head-dependent sink function (Ryder, 1982) for the steady-state simulation. The sharp-interface boundary was assumed not to have moved significantly during the short period of time (several days) that would be required for the flow field to reach equilibrium. However, over a 100-year simulation period, the freshwater flow field will decrease in size and, consequently, the fluxes would be redistributed. An incorrect distribution of fluxes in the flow model might minimize the landward movement of the interface in the transport model by allowing freshwater to leave the system too near the coast.

Simulated flux was reduced by 25 percent within the cross-sectional flow model due to the $60-\mathrm{Mgal} / \mathrm{d}$ pumpage. Specified flux in the SUTRA model was reduced by that percentage, and the model was run until simulated salinity contours did not change. This required a simulated timespan of about 100 years. The maximum lateral and upward displacement of the 50-percent salinity contour was 450 feet and 75 feet, respectively.

Pumpage in the regional areal-flow model was then doubled, at the same two points as previously mentioned, to rates of 40 and $80 \mathrm{Mgal} / \mathrm{d}$. This run resulted in an additional 2 feet of head decline at $\mathbf{A}^{\prime}$ and a new head of 8 feet. Flowlines were still parallel to the plane of section $A-A^{\prime}$ The new pumpage resulted in a 44-percent reduction of the original predevelopment flux based on the cross-sectional flow model. The SUTRA model was then run with this percentage of reduced flux; after a 100-year period simulation, salinities had nearly stabilized. The maximum lateral and upward displacement of the 50-percent salinity contour was 900 feet and 115 feet, respectively.

When pumping $120 \mathrm{Mgal} / \mathrm{d}$, the maximum lateral displacement of the 5-percent salinity contour was significantly larger than the 50-percent contour1,200 feet compared to 900 feet (fig. 18). The same is true for maximum upward displacement -250 feet compared to 115 feet. The 5-percent contour was displaced landward fairly uniformly in the upper, more permeable zone in contrast to the 50-percent contour. Landward displacement of both contours is relatively small in the lower, less permeable zone.

\section{Manatee County}

The Manatee County model area extends in cross section along E-E' (fig. 1) from southern Pinellas County, under Tampa Bay, and inland under Manatee County for about 15 miles. The modeled area is a confined, multilayered aquifer system extending horizontally for a total of 23 miles. The modeled area extends vertically 1,083 feet to the base of the permeable rock within the Upper Floridan aquifer.

\section{Conceptual Model}

Although there are discontinuous zones of relatively high and low transmissivity, the section can be considered conceptually as having four layers. From top to bottom, the section consists of the intermediate aquifer system and three layers within the Upper Floridan aquifer. The three layers of the Upper Floridan aquifer consist of a relatively high transmissivity layer (Tampa Limestone) on top, a relatively low transmissivity layer (Suwannee and Ocala Limestones) in the middle, and another relatively high transmissivity layer (Avon Park Formation) on the bottom, following Hickey's (1982) zonation of the Upper Floridan aquifer at southwest St. Petersburg.

The conceptual model (fig. 20) assumes that freshwater enters on the inland side of the system and flows along a flow path that ends in Tampa Bay on the Gulf of Mexico. Some of the freshwater in the upper layer is lost as discharge to the intermediate aquifer system, and the remainder of the flow continues beneath Tampa Bay and partially mixes with moderately saline water beneath Pinellas County. Horizontal flow and freshwater are largely maintained within the upper aquifer layer. Freshwater entering the lower layer also flows mainly toward the coast. Freshwater flowing in this layer encounters seawater much sooner than in the upper layer. Insufficient water-quality data preclude a precise cross-sectional definition of the interface; however, because brackish water was obtained during pumping of the 900- to 940-foot interval at well TR8-1 and saline water was encountered in the 1,130 - to 1,170-foot interval and because Hickey reported saline water in zone $\mathrm{C}$ in Pinellas County, it is presumed that the lower permeable zone becomes totally saline somewhere between Manatee County and Pinellas County beneath Tampa Bay. When freshwater encounters the saltwater wedge, the flow direction turns upward as the less dense freshwater rises above the higher salinity water. 


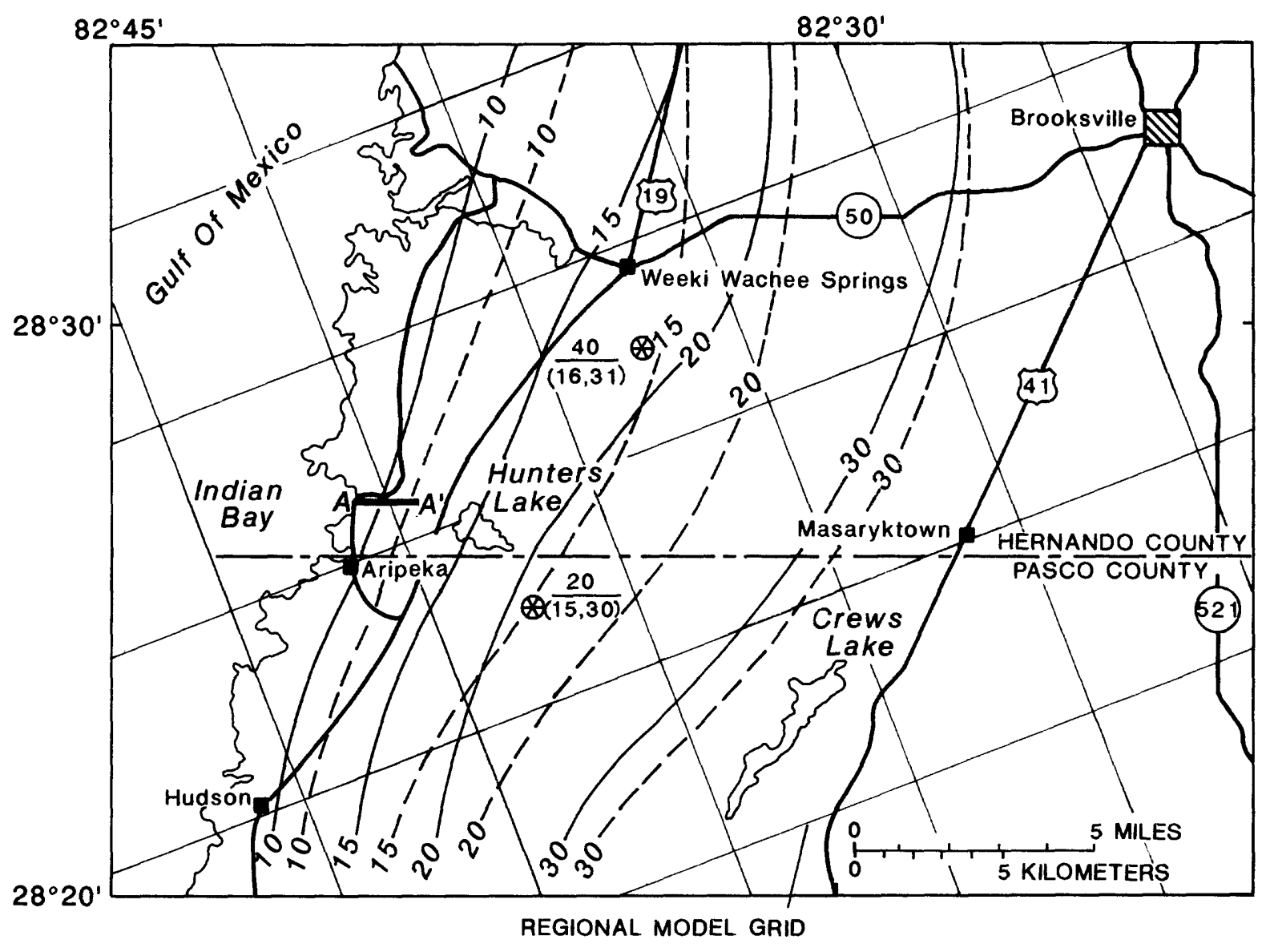

\section{EXPLANATION}

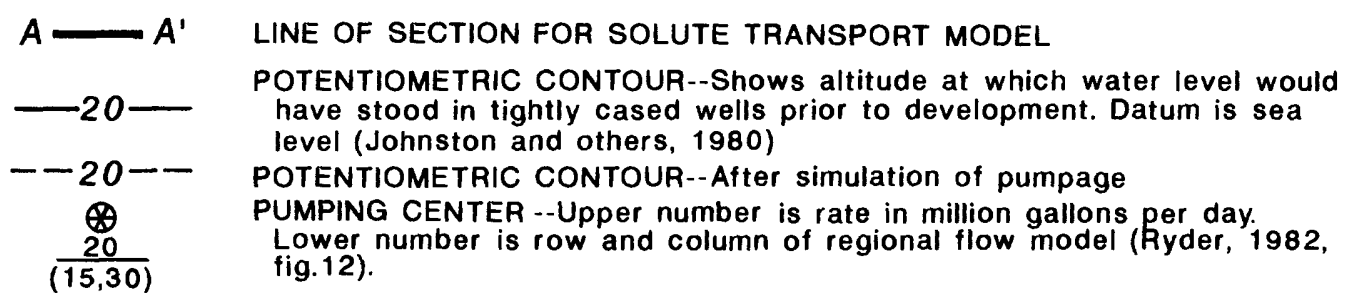

Figure 19. - Potentiometric surface of the Upper Floridan aquifer in Hernando County and adjacent areas prior to development and after simulation of hypothetical pumpage.

(Superimposed grid and regional flow model from Ryder, 1982.) 


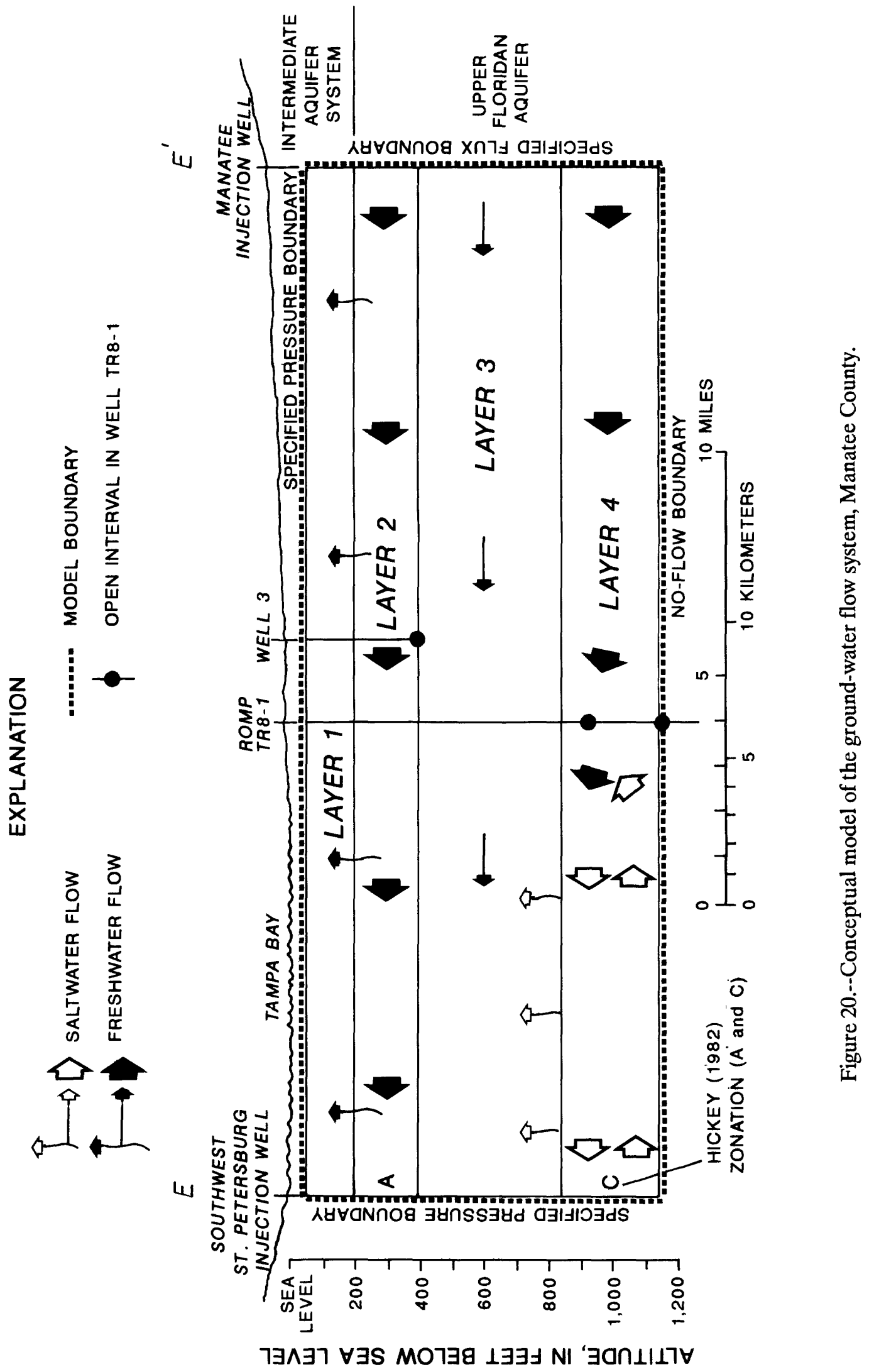




\section{Solute-Transport Model}

A solute-transport model was developed for the Manatee County transect utilizing the SUTRA code (Voss, 1984). However, calibration of the solutetransport model in Manatee County was not possible due to insufficient water-quality data from permeable zones within the lower layer and the lack of data from all zones beneath Tampa Bay, where substantial water-quality and permeability changes occur. These data are necessary during calibration for comparison with model-derived concentrations. It is possible to use the model to enhance the understanding of the subsurface by observing changes to the concentration distribution and pore-velocity fields that result from simulations using boundary conditions that are appropriate for field conditions and assuming reasonable ranges of various input parameters. The model includes 1,617 nodes (21 rows and 77 columns) and 1,520 elements. Element size is uniform (except in the upper confining unit) with a horizontal dimension of 1,601 feet and a vertical dimension of 49.21 feet. The vertical dimension of the elements that compose the intermediate aquifer system is 147 feet. Thickness of the grid is 3.281 feet.

Predevelopment conditions were used to develop a solute-transport simulation because, since about 1950 , the potentiometric surface and flow paths change seasonally due to ground-water pumpage for irrigation, thus violating a limitation of twodimensional, cross-sectional modeling. Although there is only a limited amount of water-quality data, the available data are from the 1970's and 1980's. It is certain that localized water-quality changes have occurred since predevelopment times, but the assumption is made that the chloride-concentration distributions have not changed substantially since predevelopment time. Therefore, comparisons can be made between observed data and simulation-derived concentration distributions based on predevelopment flow conditions.

Boundary conditions for the model simulations include a specified pressure and concentration boundary on the saltwater side. The values were determined using a pressure boundary generator and then modified to alleviate oscillations in the flow field in the vicinity of the boundary (C.I. Voss, U.S. Geological Survey, oral commun., 1986). Concentration values on the saltwater side of the model were obtained from data collected at the southwest St. Petersburg injection well (Hickey, 1982). The boundary at the top of the model is also specified pressure and concentration with values determined from the altitude of the potentiometric surface of the intermediate aquifer system (Duerr and others, 1988). Where the intermediate aquifer system is absent, pressure is determined from the mass of the water column above the node. Along the landward edge is a specified flux boundary with freshwater influx values that are determined from the potentiometric gradient and transmissivity values that are appropriate for the various scenarios being tested. The base of the aquifer is simulated as a no-flow boundary because permeability is very low beneath the lower layer (Hickey, 1982).

The model is comprised of four generalized layers that represent laterally persistent permeable and semipermeable zones in the subsurface. However, the boundaries of the zones and the model layers do not necessarily coincide because of the discontinuous nature and the structural orientation of the permeable zones. The uppermost model layer represents sediments within the intermediate aquifer system and is simulated as a confining unit to limit the vertical flow of fluid out of the model. The second layer, consisting of four rows of elements, represents the uppermost permeable zone (the Tampa Limestone) in the Upper Floridan aquifer. In layer three, there are nine rows of elements that represent a large sequence of semipermeable rock (the Suwannee and Ocala Limestones) that separates the upper and lower permeable zones. The permeable zones within the Avon Park Formation are represented by the fourth layer, which contains the lower six rows of elements in the model.

A preliminary steady-state, constant-density model was run and pressures were determined for a freshwater flow field. From these data, an initial pressure distribution was developed so that the flow field was stable in the early simulation time. Transport simulations were then begun using the pressure distribution from the steady-state, freshwater run. The initial concentration of solutes in the aquifer fluid was equivalent to freshwater. Saltwater was allowed to enter the system during the model run using the previously described boundary conditions. Simulations were terminated when the position of the freshwater-saltwater interface stabilized from one timestep to the next. Several thousand years of simulated flow were needed for the interface to move inland somewhere beneath Manatee County and to stabilize in time and space. 
SUTRA model input parameters (unchanging between simulations), as defined by Voss (1984), are as follows:

Anisotropy: $=\frac{\text { PMAX }}{\text { PMIN }}=1: 1$ [dimensionless],

Porosity: POR $=0.15$ [dimensionless],

Base fluid density: RHOWø $=1,000 \mathrm{~kg} / \mathrm{m}^{3}$,

Fluid coefficient of density change with concentration: DRWDU $=700 \mathrm{~kg} / \mathrm{kg} \cdot \mathrm{m}^{3}$,

Base fluid solute concentration: URHOW $\emptyset=$ 0.00 [dimensionless],

Solute concentration of saltwater entering the aquifer: $\mathrm{UBC}=0.0357$ [dimensionless],

Fluid viscosity: VISC $\emptyset=1 \times 10^{-3} \mathrm{~kg} / \mathrm{m} \cdot \mathrm{s}$,

Gravitational acceleration: GRAVY $=-32.2 \mathrm{ft} / \mathrm{s}^{2}$,

Upstream weighting factor: UP $=0.00$ [dimensionless],

Specified pressure boundary condition factor: $\mathrm{GNU}=0.033 \mathrm{ft} \cdot \mathrm{s}$,

Longitudinal dispersivity: ALMAX $=200.1$ feet,

Transverse dispersivity: ATAVG $=20.0$ feet.

Anisotropy (ratio between lateral and vertical hydraulic conductivity) was estimated to be 1:1. Porosity values were obtained from borehole geophysics estimates of bulk porosity for the permeable zones. The value of fluid coefficient of density change with concentration provides a numerically stable solution of saltwater density based on a freshwater density of $1,000 \mathrm{~kg} / \mathrm{m}^{3}$ and a seawater salinity of $35.7 \mathrm{mg} / \mathrm{L}$ (C.I. Voss, U.S. Geological Survey, oral commun., 1986). The value of fluid viscosity was taken from Weast (1972) for freshwater. Upstream weighting factor and specified pressure boundary factor are suggested by Voss (1984). Dispersivity values are dependent on and were calculated by a relation between dispersivity and element length to produce a stable, nonoscillating solution of the concentration field (Huyakorn and Pinder, 1983).

Three model simulations were made to simulate the effects of contrasting scenarios of transmissivity and freshwater influx. In the first simulation, a simple distribution of transmissivity is used. In all simulations, leakance between the intermediate aquifer system and the Upper Floridan aquifer is simulated using a value of intrinsic permeability equivalent to a leakance value of $10^{-6}(\mathrm{ft} / \mathrm{d}) / \mathrm{ft}$ in layer 1 , which corresponds to the field estimate of between $10^{-5}$ and $10^{-6}(\mathrm{ft} / \mathrm{d}) / \mathrm{ft}$ (Brown, 1983). The second layer is simulated with a transmissivity value of $70,000 \mathrm{ft}^{2} / \mathrm{d}$.
Within the Suwannee-Ocala semipermeable layer (layer 3), the Suwannee Limestone has a relatively high transmissivity and is horizontally continuous; however, the zone is thin and is masked by the hydraulic character of the much thicker Ocala rock of much lower transmissivity. The third layer is simulated with a transmissivity value of $900 \mathrm{ft}^{2} / \mathrm{d}$. The transmissivity in the lower layer was simulated using a value of $750,000 \mathrm{ft}^{2} / \mathrm{d}$ on the seaward side and changed at an arbitrary position beneath Tampa Bay to a value of $20,000 \mathrm{ft}^{2} / \mathrm{d}$ (fig. 21).

The simulated lateral position of the freshwater-saltwater interface is affected by the freshwater head in the aquifer, which is determined by several factors. These factors include the relation between the freshwater influx rate, the permeability of the matrix into which the freshwater is entering, the permeability of the upper confining unit, and the pressures on the seawater side of the model. The initial gradient that was used to determine the influx rates on the freshwater side of the model is based on the predevelopment potentiometric surface determined by Johnston and others (1980) (fig. 2). Values of influx based on this gradient in the simulation were too high and restricted the inland migration of the leading edge of the interface to somewhere beneath Tampa Bay, as shown in figure 21. Subsequent simulations were made using influx rates that were reduced from the original rates to allow heads to be about $\mathbf{1 0}$ percent lower than predevelopment heads. The lower rates allowed the interface to move inland to a new position farther beneath coastal Manatee County (figs. 22 and 23).

The need to use reduced influx rates for the computer simulations can be explained. The influx rate was determined by calculating the quantity of water that passed a given area based on the hydraulic characteristics of the matrix and the hydraulic gradient in the area. Predevelopment water levels in southernmost Pinellas County (fig. 2) are actually lower than the water levels in recent years (figs. 3 and 4), which suggest that southern Pinellas County data used for predevelopment potentiometric surface maps were somewhat low. Consequently, the specified pressure boundary values used on the seawater side of the model for numerical simulations also will be low. Increasing the pressures at this boundary results in a decrease in the quantity of freshwater necessary to maintain reasonable values of head on the freshwater side of the model. Increasing the pressures on the saltwater boundary allows the interface to move farther inland. 


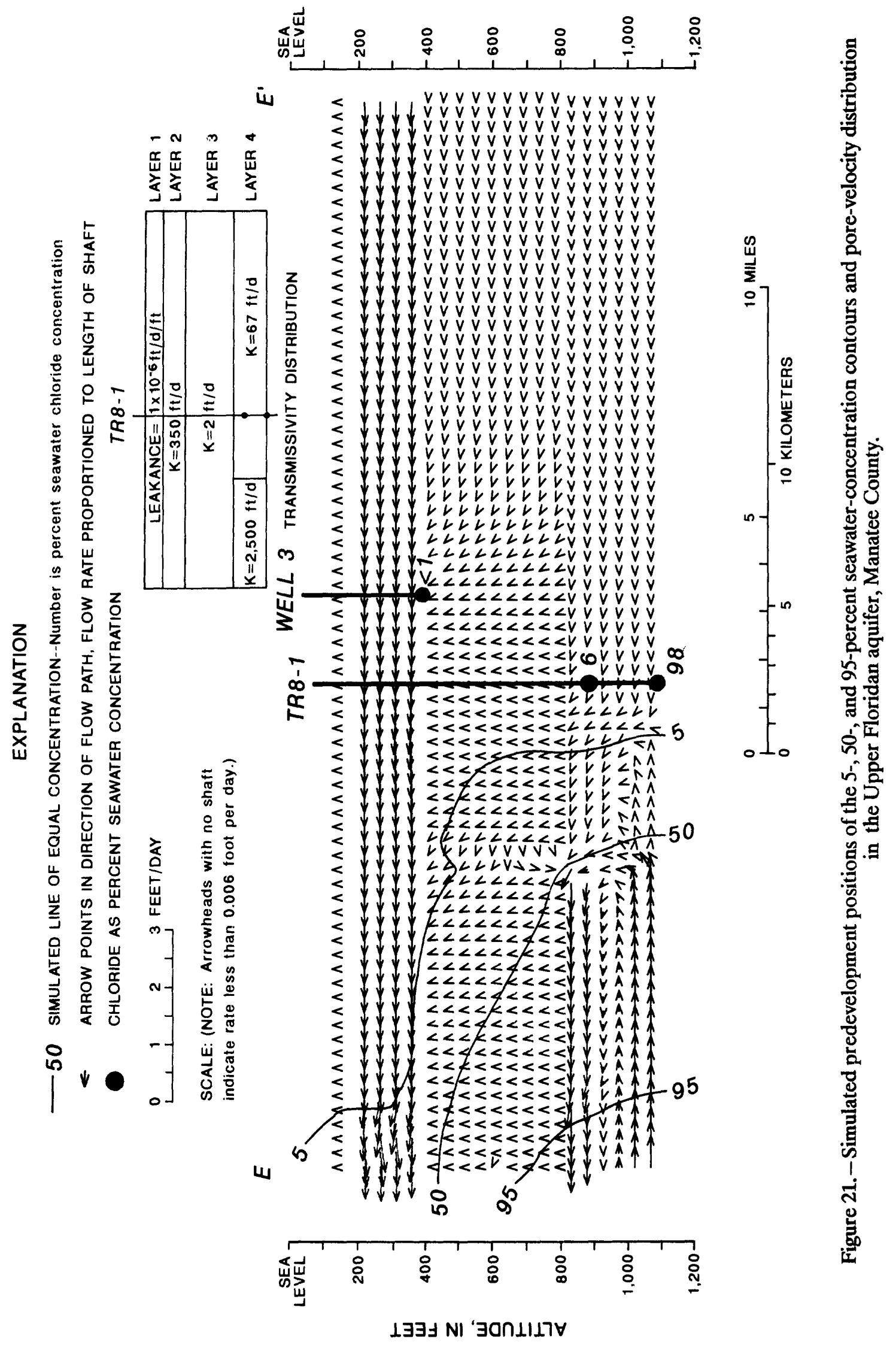




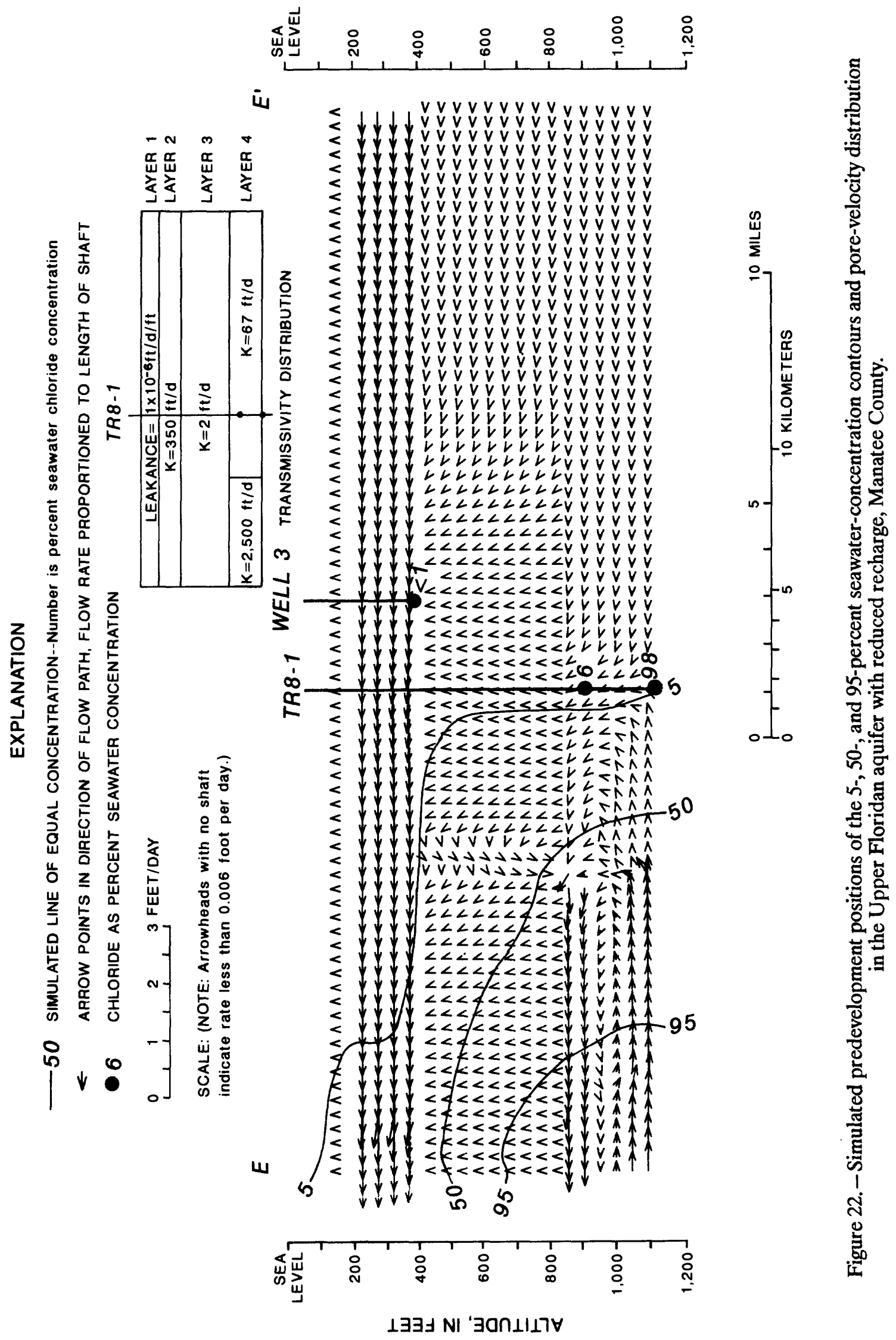




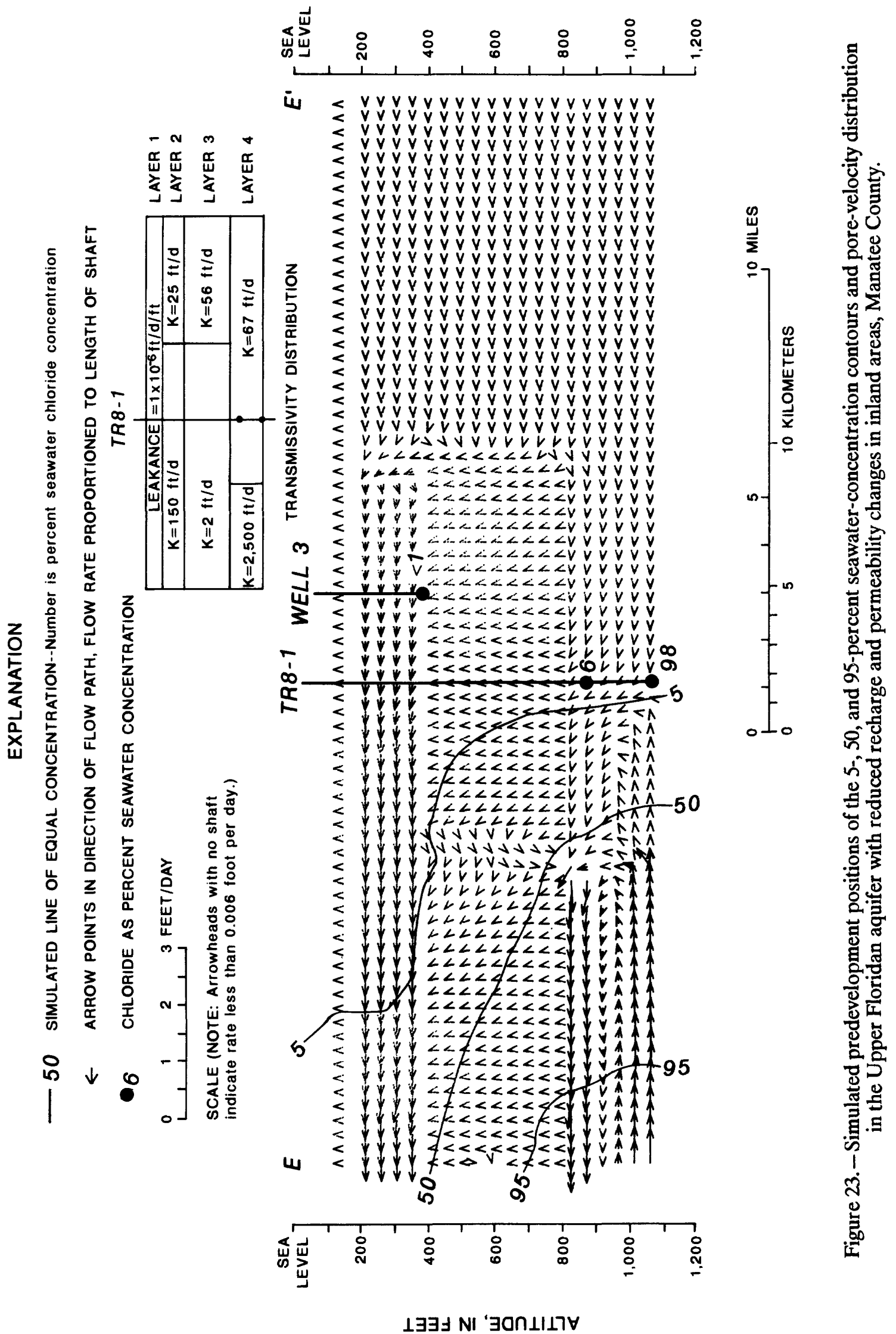


A second explanation is simpler. Preliminary information (W.B. Smith, Southwest Florida Water Management District, oral commun., 1987) suggests that predevelopment data collected in inland areas may have been based on water levels that were unusually high as a result of above average precipitation in central Florida in the mid-1900's. Less precipitation would reduce recharge into the Upper Floridan aquifer and, consequently, reduce the hydraulic gradient portrayed by the predevelopment potentiometric surface map.

The second model simulation differed from the first simulation only by the decrease in freshwater influx. In the third simulation, the transmissivity was adjusted to observe the relation of flow and solute transport resulting from a more complex transmissivity distribution (fig. 23). The transmissivity in layers 2 and 3 changes abruptly at an arbitrary distance of about 15 miles from the seaward boundary. In layer 2 , the transmissivity is $30,000 \mathrm{ft}^{2} / \mathrm{d}$ on the seaward side and $5,000 \mathrm{ft}^{2} / \mathrm{d}$ on the inland side. In layer 3, the transmissivity is lower on the seaward side than on the freshwater side and increases from $900 \mathrm{ft}^{2} / \mathrm{d}$ to $25,000 \mathrm{ft}^{2} / \mathrm{d}$, respectively.

Velocity vectors shown in figures 21 through 23 are plotted at the centroid of each element. The velocity of the fluid in an element is a function of the permeability, the pressures at the cornering nodes, and the porosity of the medium. The highest velocities that result from these simulations occur in the upper layer, and the lowest velocities occur within the confining unit that represents the intermediate aquifer system. There are distinct contrasts in the magnitude and direction of the velocities at the contacts between layers where permeability changes occur.

Plots of the simulated velocity flow fields (figs. 2123) indicate that incoming freshwater moves coastward in the Upper Floridan aquifer. The simulated confining unit at the top of the model regulates vertical flow out of the system. Horizontal flow is maintained within the upper permeable zone except for slight vertical components in the area above the front of the interface. Flow in the middle semipermeable layer is directed vertically in the vicinity of the convection cell according to this conception and lends an explanation for the presence of low salinity water in the upper permeable zone in southern Pinellas County. A convection cell develops in the lower layer as a result of fluid density contrasts between the saline water flowing inland and the freshwater flowing seaward. These simulated flow conditions, like those at Aripeka, are similar to Cooper's theories (Cooper and others, 1964). The convection cell extends from the seawater boundary about 10.5 miles based on the hydraulic parameters of the model simulation.

A change in the flow pattern of the convection cell develops as a result of the permeability change within the lower layer. It is not known whether the true permeability change is sharp or gradual or exactly where it occurs. For simplicity, it is simulated as a sharp change. In the model, this change causes pressure differences between nodes that result in deflections in the direction of flow within the lower layer and also in the middle semipermeable layer above (figs. 21 and 23 ).

The velocity-vector plot for the third simulation illustrates the effect of the transmissivity break in the upper and middle layers on the freshwater side of the model. This change in transmissivity does not have a dramatic effect on the solute distribution, but illustrates that solute could be transported vertically as a result of lateral transmissivity contrasts in the subsurface, depending on where the transmissivity contrasts occur.

The ability to match the field data from both screened intervals at well TR8-1 to the simulated concentration distribution in the simulations was poor, probably as a result of small-scale lateral and vertical transmissivity contrasts not accounted for in the model. In particular, the concentration of the water sampled from the lower interval is near seawater salinity, whereas the modeled solute concentration is very low. Simplifying the hydrogeology for modeling purposes resulted in a high transmissivity adjacent to the position of the lower screen. A very steep interface in the lower layer results from this condition, yielding virtually the same concentration adjacent to both screens (figs. 21, 22, and 23). Other sources of highly mineralized water, such as evaporites or unflushed highly saline water and a nonequilibrated, prepumping condition, are other explanations for the inability to match the existing field data. Since limited field data exist, assumptions can be made only about the input parameters, and consequently, a very detailed model is not justified.

\section{POTENTIAL FOR SALTWATER INTRUSION}

Saltwater intrusion has occurred and will probably continue to occur as population growth increases and additional ground water is withdrawn to meet the demands for water in west-central Florida. Under predevelopment conditions, there were fluctuations in the potentiometric surface that resulted from seasonal variations in precipitation. These 
fluctuations maintained a zone of dispersion along the freshwater-saltwater interface. Present-day pumpage has increased the degree of fluctuation, as shown in the middle graph of figure 13 , and probably has increased the size of the zone of dispersion. On a regional level, the areas most susceptible to saltwater intrusion will be those along the coast where the freshwater-saltwater interface migrates inland in response to a general lowering of the potentiometric surface over time. On a local scale, increases in chloride concentrations occur when individual or groups of wells pump sufficient quantities of water at rates high enough to cause upconing of brackish or saline water from permeable or semipermeable zones below.

In Hernando County, there is a potential for saltwater intrusion because of residential and commercial development east of U.S. Highway 19. As mentioned previously, this development will probably result in greater use of the ground-water resources, which, in turn, will lower the potentiometric surface of the Upper Floridan aquifer and potentially allow saltwater to move inland from the Gulf of Mexico. Computer simulations have shown, however, that the response of the interface to lowering of the potentiometric surface does not occur in the same timeframe as water-level changes. Equilibration of the concentration field is a much slower process than that of the flow field because during concentration equilibration the process of water replacement actually occurs, whereas pressure transfers within the aquifer account for rapid flow-field reequilibration. During the model simulations, the flow field reequilibrated within days as a result of large ground-water withdrawals inland. The solute concentration, however, took about 100 years to reach a new equilibrium for the same pumpage. On a regional scale, this implies that, although water levels may decline slightly, large-scale changes in water quality may not occur until years later. On a smaller scale, local deterioration of water quality might occur as a result of pumpage near the coast or where permeable zones in the limestone associated with secondary permeability act as conduits for movement of saline water. These local effects may be noticed much sooner than the regional effects.

The potential for saltwater intrusion problems in Manatee County are just as severe as in Hernando County because of increasing industrial and agricultural withdrawal of ground water. Mining in eastern Manatee County and in Polk County requires large quantities of water that are pumped predominantly from the lower permeable zone of the
Upper Floridan aquifer (layer 4, fig. 20) where transmissivity is high. A decline in the potentiometric surface of the lower zone can result in a reversal of the flow direction in central Manatee County. The potential for inland flow of saline water, therefore, is increased in coastal regions. Mining use has declined recently in eastern areas because of more efficient reuse of process water, thus alleviating some of the stress on the ground-water system.

Hickey (1982) supported the theory that saltwater is flowing inland below Pinellas County and Tampa Bay by constructing three-point problems that represent the plane of the top of the saltwater interface within the lower permeable zone. The problems were constructed using both May and September water levels. The results of the problem showed that the dip of the plane is directed away from Pinellas County toward southern Hillsborough and Manatee Counties at an azimuth of about 110 degrees (east-southeast). The plane had a gradient along the azimuth of about $0.2 \mathrm{ft} / \mathrm{mi}$ during both the wet and dry seasons.

In coastal and central areas of Manatee County, the upper permeable zone (layer 2, fig. 20) is pumped for irrigation. Figure 3 shows the potentiometric surface in May 1982 where irrigation during the dry season and reduced recharge have caused gradual declines in water levels. Most notable are the depressions in the potentiometric surface only a few miles inland from the Tampa Bay coast. Water levels depicted by the potentiometric surface maps are derived largely from wells open to the upper permeable zone of the Upper Floridan aquifer in coastal areas. Lowering of the water levels in the upper zone not only induces flow eastward beneath the bay but also may induce downward flux of saline water across the confining units beneath Tampa Bay. Obviously, the potential for saltwater intrusion is greatest during the dry season. The saltwater intrusion potential decreases during the wet season as the potentiometric surface approaches levels similar to predevelopment. However, seasonal fluctuations increase the size of the zone of diffusion between freshwater and saltwater.

Computer simulations in Manatee County have shown maximum saltwater influx rates of about $0.5 \mathrm{ft} / \mathrm{d}$ in the lower permeable zone based on the input parameters used. Hydraulic response of the system to new conditions is very quick compared to the response of the solute distribution. These results are similar to Hernando County where the maximum saltwater influx rate is about $1 \mathrm{ft} / \mathrm{d}$, whereas the return of the solute distribution to steady state is measured 
in tens or hundreds of years depending on the stress to the system. The simulations have shown that saltwater contamination of coastal wells might not be noticed as soon as water-level declines that result from pumpage inland. Similarly, improvements to water quality in coastal wells will not be apparent as quickly as rising water levels that would result from reduction of pumpage.

Some relief from saltwater intrusion may occur in Manatee County due to the phosphate industry's water conservation program that has resulted in a decrease in pumpage of water from deep permeable zones. Withdrawals for agriculture may also decrease as more efficient irrigation methods are implemented.

\section{SUMMARY AND CONCLUSIONS}

Two sites in west-central Florida were selected to study the phenomenon of saltwater intrusion because of their contrasting hydrologic conditions and their potential for saltwater intrusion resulting from increased residential, agricultural, and industrial development. Movement of the freshwater-saltwater interface at the Hernando County site was simulated in a two-dimensional solute-transport model. Coastal freshwater supplies can be contaminated by saltwater intrusion resulting from ground-water withdrawals several miles inland, but the movement of saltwater will be slow in response to changes in pumping. The impact of such contamination depends on rate and distribution of pumpage, well depths, and proximity to the coast. Seawater contamination of coastal Manatee County wells might also occur under similar conditions; however, specific rates of contamination could not be predicted by computer simulation during this investigation due to uncertainties concerning the hydrologic system.

Each site is centered around a ROMP well that had been deepened and completed with a cluster of monitor tubes open to the freshwater-saltwater transition zone and to the permeable zones above and below. The wells were developed and the hydraulic characteristics of the aquifer were tested. They were logged for geologic and water-quality information and monitored to observe the relation between water-level fluctuations and water-quality changes. The following well data resulted from these evaluations:

\section{ROMP TR18-2 in Hernando County}

- Hydraulic testing showed a permeable zone from the bottom of the casing at 447 feet to 500 feet. The estimated transmissivity of $56,000 \mathrm{ft}^{2} / \mathrm{d}$ probably includes permeable zones above the bottom of the casing.

- Freshwater with chloride concentrations of a few milligrams per liter was present to a depth of about 500 feet. A freshwater-saltwater transition zone occurred between 500 and 560 feet, below which saltwater was present with chloride concentrations of about $18,000 \mathrm{mg} / \mathrm{L}$.

- From March 29 to April 3, 1984, specific conductance in the transition zone ranged from 25,500 to $29,000 \mu \mathrm{S} / \mathrm{cm}$, changing in response to tidal fluctuations in the Gulf of Mexico.

ROMP TR8-1 in Manatee County:

- Hydraulic testing indicated transmissivity is lower in coastal Manatee County than in eastern Manatee County and across Tampa Bay in southern Pinellas County. Specific capacity tests indicated that the transmissivity of the Upper Floridan aquifer near Rubonia is about $8,500 \mathrm{ft}^{2} / \mathrm{d}$, and more than 80 percent of the flow comes from the uncased interval between 462 and 586 feet below land surface. Part of this flow might be derived from permeable zones above the bottom of the casing that are hydraulically connected to the production zone.

- Background chloride concentrations of the freshwater in Manatee County range from 25 to $50 \mathrm{mg} / \mathrm{L}$. The freshwater-saltwater transition zone is present in the permeable unit between about 875 and 975 feet, below which chloride concentrations quickly approach $19,000 \mathrm{mg} / \mathrm{L}$.

- Water-level fluctuations in the monitor tube open to the transition zone result from both tidal fluctuations and water-level fluctuations caused by pumping from the aquifer. Specific conductance of the water in the zone fluctuated in response to changes in water level. The specific conductance did not fluctuate as much as in the Hernando County well, possibly because the conductance probe at the Manatee well was set in the upper part of the interface.

Freshwater was found in the well at both sites at a depth greater than would be expected if the saltwater were static and the Ghyben-Herzberg theory was applied. The lower position of the interface might result from the cyclic flow of saltwater. In Manatee County the lower interface position may also reflect saltwater pumping in nearby mines or by contrasts in the hydraulic conductivity of the rock.

The freshwater-saltwater transition zone in Hernando County is only a few hundred feet thick, and the slope of the transition zone from the shoreline 
inland is steep relative to coastal areas a few miles to the north and south. In Manatee County, the transition zone is considered to be several hundred feet thick and the interface slope is very gradual.

Ground-water flow and solute-transport models were developed in cross section to simulate the ground-water system in both study areas. The Hernando County models were calibrated to 1982 steady-state flow conditions and to the 1982 position of the freshwater-saltwater transition zone. The solute-transport model closely matched observed salinity data. A simulated pore-velocity plot shows that velocities are about two orders of magnitude higher in the upper zone than in the basal, less permeable zone. The Manatee County model was developed to represent predevelopment flow conditions as present-day heads and flow paths vary from one season to the next. Simulations in Manatee County were run to test conceptual models of the system, but due to insufficient water-quality and hydraulic data in the coastal area and beneath Tampa Bay, simulation results are tentative. Simulated pore-velocity plots suggest that saltwater might enter the aquifer in the lower, high permeability layer and is transported to the upper permeable zone across the semiconfining unit between them. Maximum simulated saltwater influx rates are about $0.5 \mathrm{ft} / \mathrm{d}$ based on the input parameters used. Using this concept, the interface within the permeable layers would be nearly vertical, whereas it is horizontal at the top of the Suwannee-Ocala semiconfining unit and becomes more vertical with depth. In the solute-transport simulations of both areas, flow within the aquifer resembles flow theorized by Cooper and others in 1964 of the cyclic flow of seawater where saltwater flows into the aquifer, mixes, and is diluted with the freshwater moving coastward, then returns back to the sea.

Following the calibration of the Hernando County solute-transport model, incoming freshwater flux was reduced by 25 and 44 percent based on hypothetical pumpages of 60 and $120 \mathrm{Mgal} / \mathrm{d}$ applied to a previously developed areal flow model. The transport model indicated that, based on these conditions, freshwater supply wells in the area could experience increases in chloride concentrations, depending upon distance from the shoreline, well depth, and pumping rate. In the models, reaction of the flow field to changes in influx occurred within several days, whereas the movement of solute took hundreds of years to reach equilibrium.

Further studies utilizing data collection and numerical modeling could be made with orientation toward movement of the freshwater-saltwater interface that results from seasonal fluctuations of the potentiometric surface. A more precise definition of the hydrogeology and water quality is necessary to build conceptual models that will enable matching of the simulated data with the field data. Additional test wells also are needed to define the hydraulic characteristics of the aquifers and confining units, especially in the Manatee County study area. Data collection also would benefit from continuous monitoring of water level and water quality of at least two wells along a flow path and open to the same permeable zone. These data could then be used to develop transient solute-transport models to simulate movement of the interface over a seasonal cycle.

The potential for saltwater intrusion increases in coastal areas as ground-water development expands to meet the needs of the growing population in westcentral Florida. The effects of saltwater intrusion probably will be noticed first in coastal areis where local pumpage causes upconing of saline water or where heads within the Upper Floridan aquifer continue to decline and saline water penetrates permeable zones that contain freshwater.

\section{SELECTED REFERENCES}

Barr, G.L., and Schiner, G.R., 1982a, Potentiometric surface of the Floridan aquifer, Southwest Florida Water Management District, May 1982: U.S. Geological Survey Open-File Report 82-697, 1 sheet.

- - - 1982b, Potentiometric surface of the Floridan aquifer, southwest Florida Water Management District, September 1982: U.S. Geological Survey Open-File Report 82-1011, 1 sheet.

Billings, M.P., 1955, Structural geology: New York, Prentice-Hall, p. 428-429.

Brooks, H.K., 1981, Physiographic divisions of Florida: Gainesville, University of Florida, Florida Cooperative Extension Service, Institute of Food and Agricultural Sciences.

Brown, D.P., 1982, Water resources and data network assessment of the Manasota Basin, Manatee and Sarasota Counties, Florida: U.S. Geological Survey Water-Resources Investigations 82-37, 80 p.

- - 1983, Water resources of Manatee County, Florida: U.S. Geological Survey WaterResources Investigations 81-74, $112 \mathrm{p}$.

Causseaux, K.W., and Fretwell, J.D., 1982, Position of the saltwater-freshwater interface in the upper part of the Floridan aquifer, southwest Florida, 
1979: U.S. Geological Survey Water-Resources Investigations Open-File Report 82-90, 1 sheet.

- - - 1983, Chloride concentrations in the coastal margin of the Floridan aquifer, southwest Florida: U.S. Geological Survey Water-Resources Investigations 82-4070, $33 \mathrm{p}$.

CH2M Hill, 1982, Recharge at Lake Manatee: Phase one, final report: Consultant's report prepared for the Manasota Basin Board, in files of the Southwest Florida Water Management District, Brooksville, Fla.

- - 1984, Drilling and testing of an exploratory test well for deep injection of municipal wastewater at the Southwest Wastewater Treatment Plant: Consultant's report prepared for and in the files of the Manatee County Public Utilities Department, Bradenton, Fla.

Chow, V.T., ed., 1964, Handbook of applied hydrology: New York, McGraw-Hill, 1,454 p.

Cooper, H.H., Jr., Kohout, F.A., Henry, H.R., and Glover, R.E., 1964, Sea water in coastal aquifers: U.S. Geological Survey Water-Supply Paper 1613-C, 84 p.

Davis, R.A., 1972, Principles of oceanography: Philippines, Addison-Wesley Publishing Co., $434 \mathrm{p}$.

Duerr, A.D., Hunn, J.D., Lewelling, B.R., and Trommer, J.T., 1988, Geohydrology and 1985 water withdrawals of the aquifer system in southwest Florida with emphasis on the intermediate aquifer system: U.S. Geological Survey WaterResources Investigations Report 87-4259, 115 p.

Duerr, A.D., and Sohm, J.E., 1983, Estimated water use in southwest Florida, 1981, and summary of annual water use, 1970, 1975, and 1977-81: U.S. Geological Survey Open-File Report 83-45, 75 p.

Duerr, A.D., and Trommer, J.T., 1981, Estimated water use in the Southwest Florida Water Management District and adjacent areas, 1979: U.S. Geological Survey Open-File Report 81-56, 58 p.

Duerr, A.D., and Wolansky, R.M., 1987, Hydrogeology of the surficial and intermediate aquifers of central Sarasota County, Florida: U.S. Geological Survey Water-Resources Investigations Report 86-4068, 48 p.

Freeze, R.A., and Cherry, J.A., 1979, Groundwater: New Jersey, Prentice-Hall, 604 p.

Fretwell, J.D., 1985, Water resources and effects of development in Hernando County, Florida: U.S. Geological Survey Water-Resources Investigations Report 84-4320, 83 p.
_- - 1988, Water resources and effects of groundwater development in Pasco County, Florida: U.S. Geological Survey Water-Reources Investigations Report 87-4188, 209 p.

Goetz, C.L., and Goodwin C.R., 1980, Water quality of Tampa Bay, Florida: June 1972-May 1976: U.S. Geological Water-Resources Investigations 80-12, 49 p.

Hem, J.D., 1985, Study and interpretation of the chemical characteristics of natural water (3d ed.): U.S. Geological Survey Water-Supply Paper 2254, $263 \mathrm{p}$.

Hickey, J.J., 1982, Hydrogeology and results of injection tests at waste-injection test sites in Pinellas County, Florida: U.S. Geological Survey WaterSupply Paper 2183, 42 p.

Hubbert, M.K., 1969, The theory of ground-water motion and related papers: New York, Hafner Publishing Co., $310 \mathrm{p}$.

Hutchinson, C.B.,1983, Assessment of the interconnection between Tampa Bay and the Floridan aquifer, Florida: U.S. Geological Survey Water-Resources Investigations 82-54, $55 \mathrm{p}$.

- - 1984, Hydrogeology of well-field areas near Tampa, Florida, phase 2-Development and documentation of a quasi-three- dimensional finite-difference model for simulation of steadystate ground-water flow: U.S. Geological Survey Water-Resources Investigations Report 84-4002, $174 \mathrm{p}$.

Huyakorn, P.S., and Pinder, G.F., 1983, Computational methods in subsurface flow: New York, Academic Press, p. 206-207.

Johnston, R.H., Krause, R.E., Meyer, F.W., Ryder, P.D., Tibbals, C.H., and Hunn, J.D., 1980, Estimated potentiometric surface for the Tertiary limestone aquifer system, southeastern United States, prior to development: U.S. Geological Survey Open-File Report 80-406, 1 sheet.

Miller, J.A., 1982, Thickness of the Tertiary limestone aquifer system, southeastern United States: U.S. Geological Survey Open-File Report 81-1124, 1 sheet.

- -1986, Hydrogeologic framework of the Floridan aquifer system in Florida and in parts of Georgia, South Carolina, and Alabama: U.S. Geological Survey Professional Paper 1403-B, 91 p., 33 pl.

Mills, L.R., and Ryder, P.D., 1977, Saltwater intrusion in the Floridan aquifer, coastal Citrus and 
Hernando Counties, Florida, 1975: U.S. Geological Survey Water-Resources Investigations 77-100, 1 sheet.

Palmer, C.E., and Bone, L.P., 1977, Some aspects of rainfall deficits in west-central Florida, 19611976: Southwest Florida Water Management District Hydrometeorological Report no. 1, 19 p.

Peek, H.M., 1959, The artesian water of the Ruskin area of Hillsborough County, Florida: Florida Geological Survey Report of Investigations 21, $96 \mathrm{p}$.

Reichenbaugh, R.C., 1972, Sea-water intrusion in the upper part of the Floridan aquifer in coastal Pasco County, Florida, 1969: Florida Bureau of Geology Map Series 47.

Ryder, P.D., 1978, Model evaluation of the hydrogeology of the Cypress Creek well field in west-central Florida: U.S. Geological Survey Water-Resources Investigations 78-79, 68 p.

_ _ - 1982, Digital model of predevelopment flow in the Tertiary limestone (Floridan) aquifer system in west-central Florida: U.S. Geological Survey Water-Resources Investigations 81-54, $61 \mathrm{p}$.

_ - 1985, Hydrology of the Floridan aquifer system in west-central Florida: U.S. Geological Survey Professional Paper 1403-F, 63 p.

Ryder, P.D., and Mahon, G.L., 1989, Potential for saltwater intrusion into the Upper Floridan aquifer, Hernando County, Florida, in Subitzky, Seymour, ed., Selected Papers in the Hydrologic Sciences: U.S. Geological Survey Water-Supply Paper 2330.

Sinclair, W.C., 1978, Preliminary evaluation of the water-supply potential of the spring-river system in the Weeki Wachee area and the lower Withlacoochee River, west-central Florida: U.S. Geological Survey Water-Resources Investigations 78-74, $40 \mathrm{p}$.

Southwest Florida Water Management District, 1984, Population estimates and projections 1980-2020.

Steinkampf, W.C., 1982, Origins and distribution of saline ground waters in the Floridan aquifer in coastal southwest Florida: U.S. Geological Survey Water-Resources Investigations Report 82-4052, $34 \mathrm{p}$.

Stieglitz, E.H., 1986, Estimated water use in the Southwest Florida Management District, 1985: Southwest Florida Water Management District, $53 \mathrm{p}$.
Trescott, P.C., 1975, Documentation of finite-difference model for simulation of threedimensional ground-water flow: U.S. Geological Survey Open-File Report 75-438, 103 p.

Trescott, P.C., and Larson, S.P., 1976, Supplement to Open-File Report 75-438, Documentation of finite-difference model for simulation of threedimensional ground-water flow: U.S. Geological Survey Open-File Report 76-591, 21 p.

U.S. Army Corps of Engineers, 1980, Water resources management study, Four River Basins Project, Florida: Department of the Army, Jacksonville District, 116 p.

U.S. Department of Commerce, 1986, High and low water predictions east coast of North America and South America including Greenland: National Oceanic and Atmospheric Administration, $288 \mathrm{p}$.

Voss, C.I., 1984, A finite-element simulation model for saturated-unsaturated, fluid-densitydependent ground-water flow with energy transport or chemically-reactive single-species solute transport: U.S. Geological Survey WaterResources Investigations Report 84-4369, 409 p.

Weast, R.C., ed., 1972, Handbook of chemistry and physics: Cleveland, Ohio, Chemical Rubber Company, 2,335 p.

William F. Guyton and Associates, 1976, Hydraulics and water quality: Consultant's report prepared for and in the files of Swift Agricultural Chemicals Corporation, Manatee Mine Site, Manatee County, Fla.

Wilson, W.E., 1982, Estimated effects of projected ground-water withdrawals on movement of the saltwater front in the Floridan aquifer, 1976-2000, west-central Florida: U.S. Geological Survey Water-Supply Paper 2189, 24 p.

Yobbi, D.K., 1983, Trends and fluctuations in the potentiometric surface of the Floridan aquifer, west-central Florida, 1961-80: U.S. Geological Survey Water-Resources Investigations 82-4086, 1 sheet.

- - 1989, Simulation of steady-state ground water and spring flow in the Upper Floridan aquifer of coastal Citrus and Hernando Counties, Florida: U.S. Geological Survey Water-Reources Investigations Report 88-4036. 